Portland State University

PDXScholar

Summer 8-26-2019

\title{
The Invasion Ecology of Ivy (Hedera spp.) in Portland's Forest Park
}

\author{
Eric Paul Butler \\ Portland State University
}

Follow this and additional works at: https://pdxscholar.library.pdx.edu/open_access_etds

Part of the Environmental Sciences Commons

Let us know how access to this document benefits you.

\section{Recommended Citation}

Butler, Eric Paul, "The Invasion Ecology of Ivy (Hedera spp.) in Portland's Forest Park" (2019).

Dissertations and Theses. Paper 5265.

https://doi.org/10.15760/etd.7138

This Thesis is brought to you for free and open access. It has been accepted for inclusion in Dissertations and Theses by an authorized administrator of PDXScholar. Please contact us if we can make this document more accessible: pdxscholar@pdx.edu. 
The Invasion Ecology of Ivy (Hedera spp.) in Portland's Forest Park

\author{
by \\ Eric Paul Butler
}

A thesis submitted in partial fulfillment of the

requirements for the degree of

\author{
Master of Science \\ in \\ Environmental Science and Management
}

Thesis Committee:

Jeffrey Gerwing, Chair

Marion Dresner

Andrés Holz

Portland State University

2019 


\section{$\underline{\text { Abstract }}$}

Invasive ivy (Hedera spp.) has extensive impacts on Pacific Northwest urban forests, many of which are not yet fully understood. In this study of Forest Park, Portland, Oregon, I evaluated several environmental variables obtained or derived from monitoring datasets at three spatial scales to determine the following: how ivy is spatially distributed; what factors are most correlated with ivy abundance; and how ivy abundance influences shrub community composition. I found that ivy is significantly clustered at all scales with multiple apparent epicenters along the park's urban periphery. Using NMDS ordination, I determined that ivy is a significant factor in the ecosystem in general and the shrub community in particular at all scales. Random Forest regression found different sets of important environmental predictors and shrub associations at each scale, but spatial relatedness and the abundance of Mahonia nervosa consistently emerged from predictor and shrub models, respectively. All this suggests that while ivy has complicated and often site- and scale-specific interactions with its environment, its clustered dispersal pattern may be at least as important as conditions in the ecosystems it invades. However, each of the monitoring datasets had significant limitations. Future research with refined data methods could be used to infer causal relationships, measure changes over time, and model ivy's ability to spread through the Forest Park landscape. 


\section{Acknowledgements}

My thanks go first and foremost to my adviser, Dr. Jeff Gerwing, and to my committee members, Dr. Marion Dresner and Dr. Andrés Holz. I owe an equally great debt to Marshall Johnson, ecologist at Portland Parks and Recreation, who is (among other things) the reason this study exists. This thesis bears the marks of many other hands who helped with its creation: Carole Hardy, whose good cheer, gift for collaboration, and organizational brilliance have helped keep me on the path on many occasions; Dr. Cat de Rivera, who provided me with the opportunity and guidance to learn and share more about ivy than I even knew there was to know; Toby Query at Portland Bureau of Environmental Services, Cody Chambers at the Forest Park Conservancy, ISS interns Scott Schlief, Joseph Gayaldo, and Stephen Ryan, Dr. Nancy Broshot at Linfield College, and Dr. Sara Eppley in the PSU Department of Biology for their important and timely contributions; my family, for keeping me alive and sane these past two years; and all my colleagues in the Gerwing/Dresner labs and elsewhere, for reasons beyond all hope of counting. I also wish to acknowledge the following organizations for graciously allowing me to present various iterations of this research at conferences and symposia: Urban Ecology Research Consortium, The Wildlife Society - Oregon, Greater Portland Sustainability in Education Network, International Association for Landscape Ecology - North America, GIS in Action, PSU Student Research Symposium, PSU Association of Environmental Science Students, and International Urban Wildlife Conference. 


\section{Dedication}

This thesis is dedicated to the memory of my grandfather, Everett Butler (1923-

2018): forester, outdoorsman, maker of things, storyteller, veteran, and truly irreplaceable human being. 


\section{$\underline{\text { Table of Contents }}$}

Abstract

Acknowledgements

Dedication

List of Tables

List of Figures

Introduction

Invasive Species in Urban Forests

Forest Park

Ivy as an Invasive Plant

Ecological Impacts of Ivy in Forest Park

Section 1: Landscape Distribution of Ivy

Question

Data

Analysis

Results

Section 2: Environmental Predictors of Ivy

Question

Data

Analysis

Results

Section 3: Ivy-Shrub Community Interactions

Question

Data

Analysis

Results

Discussion

Findings

Study Limitations

Future Research

Management Implications

References 


\section{List of Tables}

Table 1: Programs and goals of the GFPCI

Table 2: Variables representing ivy abundance and its potential predictors at the landscape scale

Table 3: Variables representing ivy abundance and its potential predictors at the intermediate scale

Table 4: Variables representing ivy abundance and its potential predictors at the site scale

Table 5: Spearman rank correlation values between ivy and environmental predictors at the landscape scale. P-values are estimates due to tie ivy scores.

Table 6: Spearman rank correlation values between ivy and environmental predictors at the intermediate scale. P-values are estimates due to tie ivy scores.

Table 7: Spearman rank correlation values between ivy and environmental predictors at the site scale. P-values are estimates due to tie ivy scores.

Table 8: Shrub species included in the community analyses at the three spatial scales. Shrubs with $<4$ detections in any sample (gray cells) were not included in the respective analysis.

Table 9: Spearman rank correlations between ivy and shrub species included in 52 analysis at the landscape scale.

Table 10: Spearman rank correlations between ivy and shrub species included in analysis at the intermediate scale.

Table 11: Spearman rank correlations between ivy and shrub species included 60 in analysis at the site scale. 


\section{List of Figures}

Figure 1: Location of Forest Park in northwestern Portland, Oregon. Forest

Park covers 2,093 ha and is part of a larger ( $6200 \mathrm{ha})$ ecological landscape

contiguous with the forest lands of the Coast Range (Myers, 2013).

Figure 2: Balch Creek Treatment Area, indicating Balch I UMP points inventoried in 2015 prior to ivy treatment. Treatment in Balch I began in 2015; treatment in Balch II began in 2018; treatment in Balch III is scheduled to begin in 2019.

Figure 3: Map of Audubon, Coyote, and Burlington permanent research plots in Forest Park (Dresner, Van Winkle, \& Franz, 2017)

Figure 4: Frequency distribution of ivy by cover class across the Forest Park landscape.

Figure 5: Spatial distribution of ivy by cover class across the Forest Park landscape.

Figure 6: Hotspot (Getis-Ord $\mathrm{Gi}^{*}$ ) analysis results for the full landscape dataset

Figure 7: Voronoi diagrams of the landscape-scale spatial distribution of ivy

(normalized values): (A) medians; (B) IQRs; (C) clustering; (D) entropy.

Figure 8: Histogram of ivy abundance in the Balch I UMP sites

Figure 9: Distribution of ivy in Balch I Treatment Area

Figure 10: Histogram of ivy abundance in the combined Audubon, Coyote, and Balch permanent research plots

Figure 11: Spatial distribution (top) and hotspot analysis (bottom) of ivy cover in the three Balch Creek permanent research plots

Figure 12: Forest Park vegetation polygons ( $\mathrm{n}=295)$, highlighting the subsample $(n=40)$ used for statistical analysis. "Ivy Present" $(n=20)$ are cover classes of 1\%-10\% or above; "Ivy Absent" (n=20) are cover classes of "none" or "trace".

Figure 13: Site-scale predictors sampling design. 
Figure 14: Stressplot of the landscape-scale NMDS ordination of

environmental variables ( 2 axes, 20 runs). A high non-metric fit $\left(R^{2}=0.968\right)$ means the ordination is a strong fit to the data, assuming monotonic but not linear relationships among variables, and a low model stress (stress $=0.1782$ ) means there were enough variables for the number of axes to explain most of the variance without overfitting the model.

Figure 15: NMDS ordination of environmental variables at the landscape scale by site. Colors represent a gradient of ivy cover class.

Figure 16: NMDS ordination of environmental variables at the landscape scale. 36 Variables significant $(\mathrm{p}<0.05)$ to the model are in bold.

Figure 17: Importance of all variables in the landscape-scale NMDS ordination model of environmental predictors.

Figure 18: Relative importance (measured as increased node purity) of independent variables in the full (top) and reduced (bottom) Random Forest regression models of predictors of ivy abundance at the landscape scale. The full model produced $50.85 \%$ explained variance; the reduced model produced $58.46 \%$ explained variance.

Figure 19: Stressplot of the intermediate-scale NMDS ordination of environmental variables $(2$ axes, 20 runs, model stress $=0.1841$ ).

Figure 20: NMDS ordination of environmental variables at the intermediate scale by site. Colors represent ivy abundance.

Figure 21: NMDS ordination of environmental variables at the intermediate scale. Variables significant $(\mathrm{p}<0.05)$ to the model are in bold.

Figure 22: Importance of all variables in the intermediate-scale NMDS ordination model of environmental predictors.

Figure 23: Relative importance of variables in the full (top) and best reduced (bottom) Random Forest regression models for the intermediate-scale predictors of ivy abundance. The full model explained $57.82 \%$ of the variance in ivy; the reduced model explained $62.15 \%$.

Figure 24: Stressplot of the site-scale NMDS ordination of environmental variables ( 2 axes, 20 runs, model stress $=0.1556)$.

Figure 25: NMDS ordination of environmental variables at the site scale by site. Colors represent a gradient of ivy abundance. 
Figure 26: NMDS ordination of environmental variables at the site scale.

Variables significant $(\mathrm{p}<0.05)$ to the model are in bold.

Figure 27: Importance of all variables in the site-scale NMDS ordination model 47 of environmental predictors.

Figure 28: Relative importance of independent variables in the full (top) and 48 reduced (bottom) Random Forest regression models of predictors of ivy abundance at the landscape scale. The full model explained none of the variance in ivy; the reduced model explained 3.02\%.

Figure 29: Stressplot of shrub community NMDS ordination at the landscape scale ( 2 axes, 20 runs, model stress $=0.1561$ )

Figure 30: NMDS ordination of shrub community composition by site at the landscape scale. Colors represent ivy cover class.

Figure 31: NMDS ordination of shrub community composition by species at the landscape scale. Species significant $(\mathrm{p}<0.05)$ to the model are in bold.

Figure 32: Importance of species to the shrub community NMDS ordination at the landscape scale

Figure 33: Relative importance of shrub species (measured as increased node purity) to the full (top) and strongest reduced (bottom) Random Forest regression models of ivy vs. shrub community composition at the landscape scale. The full model explained $28.64 \%$ of the variance in ivy; the reduced model explained $34.38 \%$.

Figure 34: Stressplot of shrub community NMDS ordination at the intermediate scale ( 2 axes, 20 runs, model stress $=0.1232$ )

Figure 35: NMDS ordination of shrub community composition by site at the intermediate scale. Colors represent ivy abundance.

Figure 36: NMDS ordination of shrub community composition by species at the intermediate scale. Species significant $(p<0.05)$ to the model are in bold.

Figure 37: Importance of species to the shrub community NMDS ordination at the intermediate scale 
Figure 38: Relative importance of shrub species to the full (top) and strongest reduced (bottom) Random Forest regression models of ivy vs. shrub community composition at the intermediate scale. The full model explained $34.54 \%$ of the variance in ivy; the reduced model explained $37.80 \%$.

Figure 39: Stressplot of shrub community NMDS ordination at the site scale ( 260 axes, 20 runs, model stress $=0.1386$ )

Figure 40: NMDS ordination of shrub community composition by site at the site scale. Colors represent ivy abundance.

Figure 41: NMDS ordination of shrub community composition by site at the site scale, comparing the three permanent research plots.

Figure 42: NMDS ordination of shrub community composition by species at the site scale. Species significant $(\mathrm{p}<0.05)$ to the model are in bold.

Figure 43: Importance of species to the shrub community NMDS ordination at the site scale.

Figure 44: Relative importance of shrub species to the full (top) and strongest reduced (bottom) Random Forest regression models of ivy vs. shrub community composition at the site scale. Neither model explained any variance in ivy.

Figure 45: Predicted abundance trends of ivy and functionally similar shrubs 72 under the superior-competitor hypothesis (L) and under the opportunisticinvader hypothesis (R). 


\section{$\underline{\text { Introduction }}$}

\section{Invasive Species in Urban Forests}

Urban forests are increasingly recognized as critical natural resources in a rapidly urbanizing world (Roy, Byrne, \& Pickering, 2012), yet they are also ecosystems subject to many and various environmental stressors even at significant distances from the urban boundary (Grimm et al., 2008). Novel conditions in urban forests include compacted or mechanically altered soils (Thomas, 1998), air and water pollution (Cavanagh, Zawar-Reza, \& Wilson, 2009), localized heat stress (Ramirez, Shandas, Rosenstiel, Prather, \& Aldrich, 2019), frequent disturbance from human activity (Van Winkle, 2014), edge effects (Barbarasch, 2005; Villasenor, Blanchard, \& Lindenmayer, 2016), and landscape fragmentation (Alberti, 2005), and the species compositions of these forests reflect these conditions. Invasive plants in particular can thrive in urban forests, as stressful environments decrease the abundance and competitive fitness of native plants (Allen et al., 2007; Beauchamp, Ghuznavi, Koontz, \& Roberts, 2013), novel disturbances and fragmentation open niches for invaders (Shea \& Chesson, 2002), and human activity (including, in some cases, deliberate introduction) creates high propagule pressure and dispersal capacity (Davis, Singh, Thill, Meentemeyer, \& Peters, 2016; Mandryk \& Wein, 2006). While these invasive plants are not always clearly negative in their ecological impacts, some can cause major alterations to the biodiversity and/or ecological functionality of invaded ecosystems, for instance by altering resource fluxes or 
disturbance regimes, or by competitively excluding comparable species of much higher habitat value. Compounding species invasions under urban stress can even lead to "invasional meltdown", in which native species assemblages are largely replaced by novel, exotic-dominated communities (Vidra, Shear, \& Wentworth, 2006). While much research has focused on removing invasive plants from individual sites, there has long been a lack of study of landscape-scale management or of post-treatment restoration (Kettenring \& Adams, 2011), as well as a "knowingdoing" gap between research and management (Esler, Prozesky, Sharma, \& McGeoch, 2010). Large, complex urban landscapes further complicate our understanding of where invasive species occur and why; while invasive species tend to increase in diversity and abundance with urbanization, both spatial and environmental factors may be responsible for their distributions (Štajerová, Šmilauer, Brůna, \& Pyšek, 2017; With, 2002). Forest Park

One of the most iconic urban forest landscapes in North America is Forest Park (Fig. 1). Located on the steep eastern slopes of the Tualatin Mountains overlooking the Willamette River, Forest Park was established in 1947 and over time has grown to 2,093 ha, in addition to other protected areas as part of a larger continuous ecosystem extending from the Coast Range into the urban core (Myers, 2013). Forest Park provides valuable services to the Portland metropolitan area ranging from recreation and wildlife habitat to natural regulation of air and water quality (Myers, 2013). 


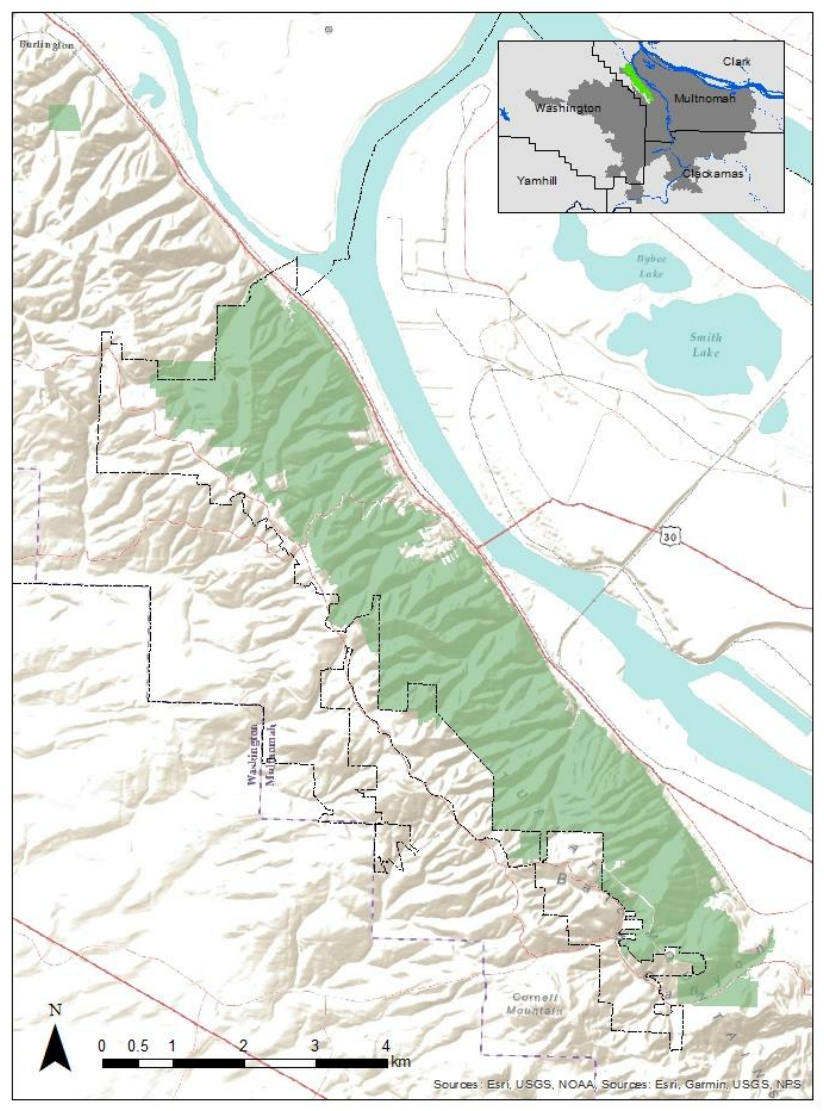

Figure 1: Location of Forest Park in northwestern Portland, Oregon. Forest Park covers 2,093 ha and is part of a larger ( $\sim 6200 \mathrm{ha})$ ecological landscape contiguous with the forest lands of the Coast Range (Myers, 2013).

Forest Park has been substantially impacted by the legacies of historical land use. Nearly the entire forest had been heavily logged and either replanted or allowed to regenerate naturally by the early $20^{\text {th }}$ Century (Houle, 1988), landslides have occurred in several areas (Burns, Madin, Ma, Mickelson, \& Saint-Pierre, 2011), wildfires burned in some areas of the southern and central sections of the park (Kuhn, 2005), neighborhoods have been built on many adjacent hillsides, and 
numerous road grades and utility rights-of-way still permeate the park (Houle, 1988).

The Greater Forest Park Conservation Initiative (GFPCI), a coalition of public and nonprofit stakeholders led by Portland Parks and Recreation (PP\&R) and the Forest Park Conservancy (FPC), has set ecology-focused management goals for Forest Park and the surrounding ecological landscape (Table 1) (Myers, 2013).

Table 1: Programs and goals of the GFPCI (Myers, 2013)

\begin{tabular}{|c|c|c|c|}
\hline Program & Lead & Goal & Notes \\
\hline Protect the Best & PP\&R & $\begin{array}{l}\text { Preserve the highest } \\
\text { quality acreage in Forest } \\
\text { Park }\end{array}$ & $\begin{array}{l}\text { Initial treatment on } 1,607 \\
\text { acres and follow-up work } \\
\text { on 1,581 acres during the } \\
\text { last } 3 \text { years }\end{array}$ \\
\hline No Ivy League & PP\&R & $\begin{array}{l}\text { Remove ivy and other } \\
\text { weeds }\end{array}$ & $\begin{array}{l}\text { Relies on volunteers, who } \\
\text { have removed ivy from } \\
\text { more than } 260 \text { acres }\end{array}$ \\
\hline $\begin{array}{l}\text { Early Detection, } \\
\text { Rapid Response }\end{array}$ & PP\&R & $\begin{array}{l}\text { Treat fast-moving } \\
\text { invasive species such as } \\
\text { garlic mustard }\end{array}$ & Involves a set of protocols \\
\hline $\begin{array}{l}\text { Habitat } \\
\text { Restoration }\end{array}$ & PP\&R & $\begin{array}{l}\text { Restore areas of park not } \\
\text { addressed through } \\
\text { Protect the Best }\end{array}$ & $\begin{array}{l}\text { Coordinates with BES } \\
\text { crews; initial treatment } \\
\text { on } 3,236 \text { acres during the } \\
\text { last } 3 \text { years }\end{array}$ \\
\hline $\begin{array}{l}\text { Habitat } \\
\text { Restoration }\end{array}$ & FPC & $\begin{array}{l}\text { Non-native species } \\
\text { removal and revegetation } \\
\text { at six sites }\end{array}$ & $\begin{array}{l}\text { Park seasonal field crew } \\
\text { of four, with an average of } \\
1,500 \text { volunteers per year }\end{array}$ \\
\hline
\end{tabular}

However, Forest Park is facing numerous issues; recruitment of late-seral trees, for instance, is rare and sporadic in the park, casting doubt on the future canopy composition (Broshot, 2011; Dresner et al., 2017). Shrub communities appear to be in decline in some areas, as well (Dresner, 2018), while a number of established or emerging invasive plants have been observed to be expanding their 
ranges in the park (M. Johnson, 2018). What environmental factors are driving these changes is not clear, but air pollution, degraded soils, recreation impacts, the ecological "resilience debts" of past land uses (Johnstone et al., 2016), and climate stresses-each a symptom of urban pressure-are all non-exclusive possibilities. Successfully managing specific ecological problems in Forest Park and other urban greenspaces requires understanding and mitigating underlying, often invisible sources of ecological vulnerability. This is particularly relevant to invasive plants, which represent one of the largest and most expensive management challenges in Forest Park; park ecologists, for instance, are currently implementing an ambitious, three-phase, nearly decade-long ivy eradication and post-treatment restoration effort in the Balch Creek watershed at the park's southern end (M. Johnson, 2018). Ivy as an Invasive Plant

Ivy (Hedera spp., Araliaceae; primarily H. hibernica in our region, though several taxa are present (Clarke, Reichard, \& Hamilton, 2006)) is an evergreen liana native to temperate Eurasia (Ramsey, 2005). It has two growth forms in forest ecosystems, as a vegetative groundcover and a reproductive climbing epiphyte (Metcalfe, 2005). Widely introduced as an ornamental species, it has become established as a serious invasive species in many temperate regions around the world, including the Pacific Northwest (Ramsey, 2005). It commonly invades forest ecosystems, where it competitively excludes herbaceous understory at high densities (Copp, 2014), potentially alters overall shrub abundance and shifts the functional composition of shrub communities in favor of dissimilar species 
(Dlugosch, 2005; Hallett et al., 2017; Quinn \& Best, 2002), and invades tree canopies, causing variably weakened growth (Ladwig \& Meiners, 2009; Yaman, 2009) and perhaps increased blowdown mortality, though the latter appears not to have been confirmed by research. On the other hand, it appears not to affect conifer seedling recruitment in our region (Dlugosch, 2005; Ettinger, Lee, \& Montgomery, 2017), and Broshot (2011) has observed a pronounced lack of late-seral trees even in ivy-free areas of the park. Similarly, while ivy may reduce seed banks indirectly by excluding source plants, it does not appear to suppress seed bank formation or germination directly (Biggerstaff \& Beck, 2007a).

Ivy is well-adapted to a Mediterranean climate, putting on much of its growth during mild winter and spring days before deciduous trees have leafed out, and conserving water during the hot, dry months of late summer (Holloway \& Rosenstiel, 2013; Leuzinger, Hartmann, \& Korner, 2011); as Portland's climate becomes warmer and seasonally drier (Turner, Conklin, \& Bolte, 2015), and ambient carbon dioxide levels increase (Zotz, Cueni, \& Korner, 2006), ivy's competitive ability is expected to increase (Leuzinger et al., 2011; Manzanedo et al., 2018). However, it likely has a fairly limited dispersal rate across the landscape; while its immature form is quite shade-tolerant (Sack \& Grubb, 2002) and can spread by fairly fast vegetative growth, it requires ample sunlight to reproduce sexually (Metcalfe, 2005), and its mildly toxic fruits have a short residence time in bird guts (Barnea, Harborne, \& Pannell, 1993). Its seeds do not persist long in the seed bank (Thompson, Bakker, \& Bekker, 1997). 
Ivy is typically controlled by either manual removal or herbicide application, which can both be highly effective but have different costs, ecological impacts, and implications for post-treatment restoration (Biggerstaff \& Beck, 2007b; Farmer, Ward, Horton, \& Clarke, 2016). Not all infestation sites (steep slopes, for instance) can be feasibly treated (Stewart, 2018), and ivy removal without active posttreatment restoration tends to result in secondary invasion by opportunistic species such as clematis (Clements \& Bierzychudek, 2017). It is also unclear if aggressive replanting, particularly of shrubs, can resist ivy (re-)infestation-in other words, if ivy is a superior competitor or if it is opportunistically invading distressed areas where native shrub communities have become less competitive (Grime, 1977). While established vegetation tends to possess a competitive advantage over new arrivals (McGlone, Sieg, \& Kolb, 2011), ivy may be taking advantage of a vacant niche in our region's mesic forests (Dlugosch et al., 2015), which lack any native evergreen lianas (Gilkey \& Dennis, 2001). On the other hand, understory communities in urban forests may be declining due to factors such as fragmentation (Cameron, Culley, Kolbe, Miller, \& Matter, 2015; Ramalho, Laliberte, Poot, \& Hobbs, 2018), pollution (Allen et al., 2007), or climate stress (Ramirez et al., 2019), creating an ecological vacuum for ivy to fill. These dynamics might vary by ecosystem type across the landscape, as well (Ramsey, 2005). Environmental Conditions Associated with Ivy Invasion

In order to produce sustainable restoration outcomes, natural resource managers need to understand the environmental conditions associated with ivy 
invasion, including shrub community composition and landscape pattern, and how to mitigate those potential vulnerabilities (Quinn \& Best, 2002). The purpose of this study is to elucidate those conditions in Forest Park on the site (3 ha), intermediate ( $\sim 70 \mathrm{ha})$, and landscape ( $\sim 2000 \mathrm{ha})$ spatial scales, as different processes might be operating at both. While Radosevich, Stubbs, \& Ghersa (2003) suggest that extrinsic (i.e., environmental) variables tend to predominate over intrinsic (i.e., reproductive and dispersal ability) traits during the mature, landscape-spread phase of species invasions, ivy's relatively slow dispersal phenology suggest its presence in the landscape might still be distinctly clustered rather than more randomly or evenly distributed. Spatial autocorrelation has been shown to determine invasive species presence on ecoregional scales more strongly than ecological conditions (Dark, 2004), while on the local landscape scale these two influences are often mixed (Tanentzap, Bazely, \& Lafortezza, 2010), and different factors may influence the behavior of invasive plants at different phases of the invasion process at a given site (Beauséjour, Handa, Lechowicz, Gilbert, \& Vellend, 2015).

Research into environmental predictors of ivy has been fairly limited. Ivy's seasonal growth pattern suggests it is likely to be more abundant under deciduous canopy (Leuzinger et al., 2011). One study from the eastern United States found that ivy is strongly associated with disturbed soils, particularly grades and artificial fill (Thomas, 1998), while research from our region found that ivy is correlated with lower soil pH and reduced leaf litter (Heckman, 2007). Ivy is known to be highly tolerant of many forms of air pollution (Della Torre et al., 1998; Jung et al., 2010), 
though atmospheric nitrate deposition has not been shown clearly to affect its productivity in Forest Park (Dolan, 2013), perhaps because $\mathrm{NO}_{\mathrm{x}}$ causes some degree of offsetting tissue damage (Saxe, 1994). Many invasive shrubs and lianas in forested areas tend to invade peripheral areas and road/trail corridors more readily than forest interiors (Bartuszevige, Gorchov, \& Raab, 2006; Tanentzap et al., 2010). While ivy abundance and community interactions appear to be different between upland and riparian areas (Ramsey, 2005), the effects of topography, soil moisture, and canopy composition in these environments have not been teased out. And, if ivy is more likely to invade sites with weakened ecological resilience from past disturbance (such as logging), its abundance might be correlated with indicators such as a lack of dead woody material (Abrego \& Salcedo, 2013) or less complex canopy structure (Woodcock, Halme, \& Edwards, 2015), but this appears not to have been investigated.

If both landscape pattern and environmental predictors can be determined at a sufficiently fine grain, it would be possible to develop a landscape resistance model (Dickson et al., 2019) indicating where ivy is most likely to spread. Such a model would enable managers to prioritize monitoring and treatment sites within a large, complex landscape such as Forest Park. In addition, understanding how shrub communities differ across a gradient of ivy invasion will help managers determine how best to restore treated sites and how best to maintain biodiversity and ecological functions in untreated areas. This requires, however, an understanding of both overall patterns and site-specific conditions, and illustrating the differences 
between the two requires studying the issue at multiple spatial scales. Landscape processes ("what to expect") inform planning, site conditions ("ground truth") inform project implementation, and the two are mutually interdependent. A landscape of the size and complexity of Forest Park, however, encompasses such diversity of ecological conditions and histories, and covers so much territory, that management decisions are likely to be made at intermediate spatial scales, and patterns and processes at these scales can link those at the site and landscape scales, or reveal dynamics missed at broader or narrower levels of analysis.

For the sake of clarity, this paper is organized into three sections, each covering a primary research question, and the data, analysis, and results answering that question at the landscape $(2,093 \mathrm{ha})$, intermediate (74 ha), and site (3 ha) scales. The first section is concerned with determining where ivy occurs, and if there is a meaningful pattern to its distribution. The second is concerned with what environmental factors, including spatial dependency, are most predictive of ivy abundance. The third is concerned with how shrub communities differ at different levels of ivy abundance. As these analyses inform each other, and the strengths and weaknesses of the source data cut across categories, the results will be discussed together at the end. 


\section{Section 1: Spatial Distribution of Ivy}

\section{Question}

Is there a meaningful and significant pattern to how ivy is distributed in Forest Park?

The spatial and frequency distributions of ivy help define the scope of its presence on the landscape and the severity of its infestation. Spatial autocorrelation, if present, might also be a significant factor in subsequent predictor models. I determined these using summary and spatial statistics on ivy abundance values from three georeferenced monitoring datasets representing different spatial extents and granularities.

Data

Ivy abundance and shrub community composition in Forest Park have been measured as part of three datasets at different spatial scales.

\section{Landscape Scale: Forest Park}

In 2003, PP\&R contracted a comprehensive survey of all its natural areas to groundtruth vegetation units identified by remote sensing analysis; Forest Park, including Holman, Macleay, and Linnton Parks, was surveyed largely in 2004 (Vegetation Unit Summaries for Forest Park, 2009). The resulting data provide cover classes $(>75 \%, 50 \%-75 \%, 30 \%-50 \%, 10 \%-30 \%, 1 \%-10 \%$, and trace [for uncommon or exotic species only]) of all vascular plants identified within each vegetation unit, including ivy, along with average canopy and slope estimates, National Vegetation 
Classification System categories, and descriptive notes on site conditions and management needs. These vegetation units existed as GIS polygons and an associated table of plant cover classes. I converted the cover classes for HEHE (Hedera helix, representing in this case all Hedera taxa) to a 0-7 integer scale and used the full dataset of GIS polygons for this analysis.

Intermediate Scale: Balch Treatment Area

As part of the Balch Creek treatment project, PP\&R and the FPC established a grid of Uniform Monitoring Protocol (UMP) points within the project area to monitor changes in vegetation pre- and post-treatment (Forest Park Conservancy, Portland Parks and Recreation, Metro, \& West Multnomah Soil and Water Conservation District, 2016) (Fig. 2). I selected a subset ( $\mathrm{n}=59$ ) of these points from the Balch I treatment area, which were surveyed in 2015, prior to the beginning of ivy treatment.

Each point serves as the reference for a 35' transect (usually on a cardinal north bearing unless this would intersect a trail or other non-vegetated feature), along which a 6 ' pole-point count of vascular plant species is taken at $1^{\prime}$ intervals. $H$. helix and H. hibernica were counted separately in this inventory but the two counts were added together for my analyses. 


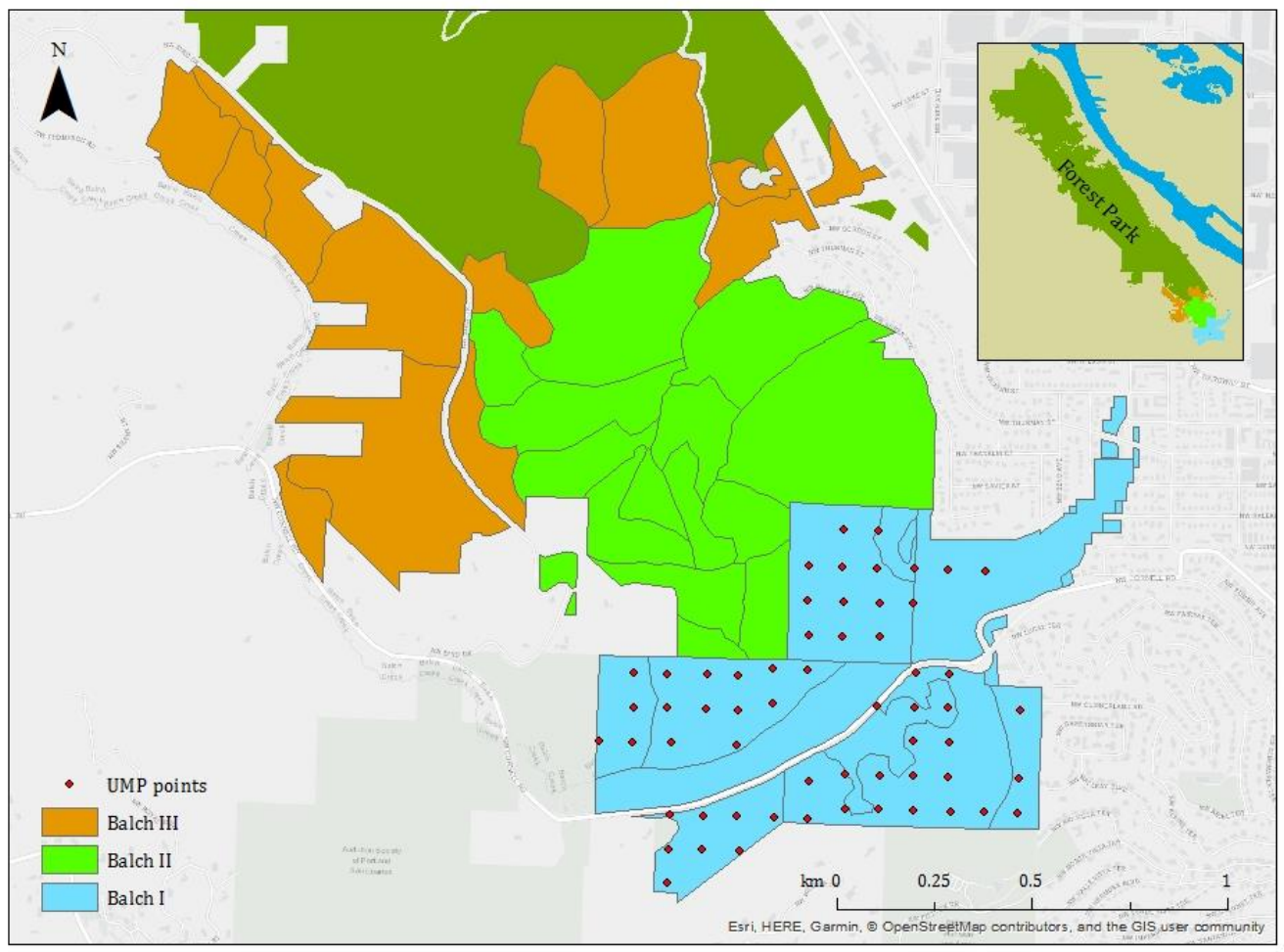

Figure 2: Balch Creek Treatment Area, indicating Balch I UMP points inventoried in 2015 prior to ivy treatment. Treatment in Balch I began in 2015; treatment in Balch II began in 2018; treatment in Balch III is scheduled to begin in 2019.

Site Scale: Balch Creek Research Plots

Copp (2014) estimated ivy cover within structured $1 \mathrm{~m}^{2}$ microplots at three 1-hectare permanent research plots (Fig. 3) in the Balch Creek area. Each plot contains 64 microplots. 


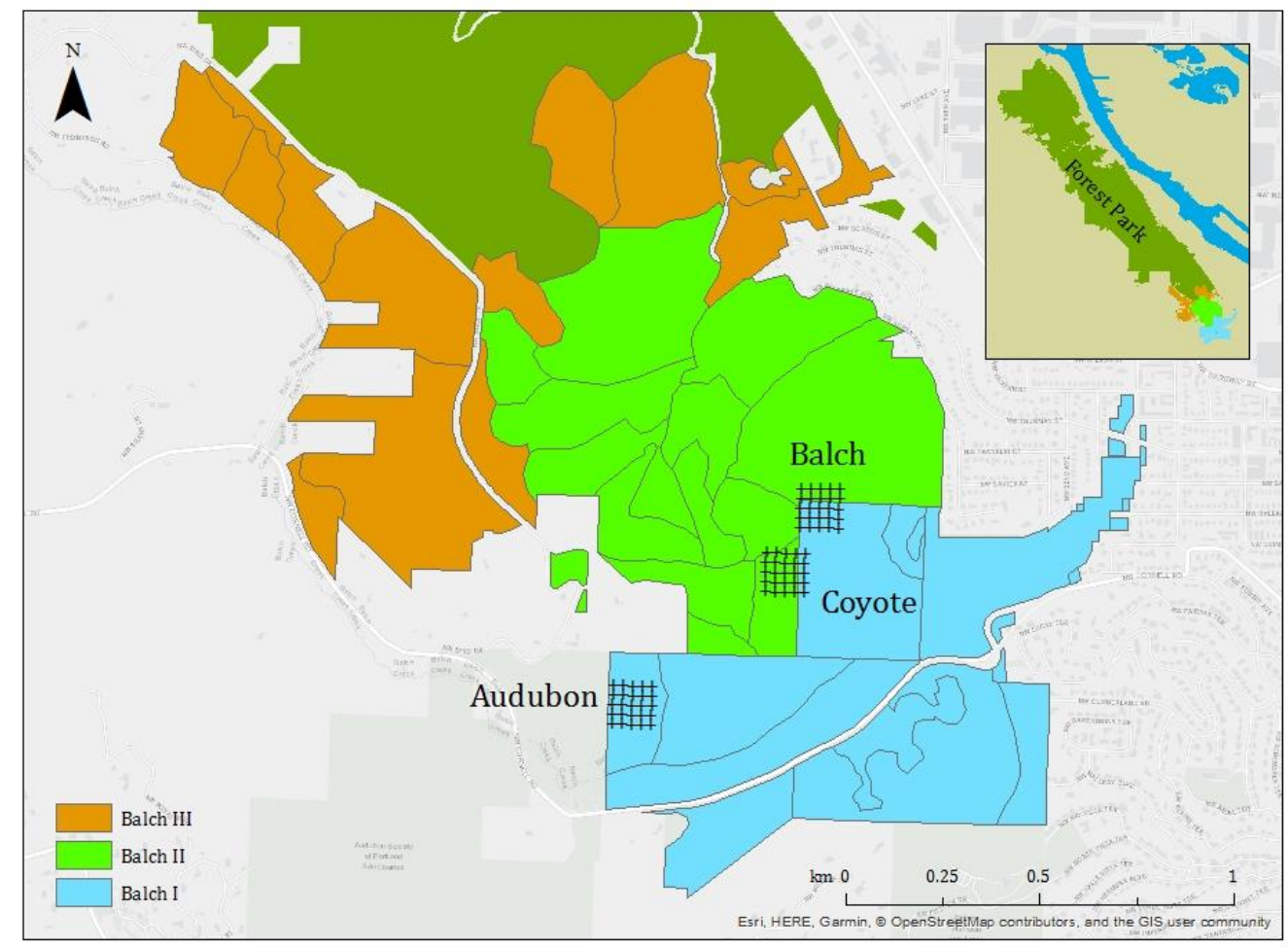

Figure 3: Map of Audubon, Coyote, and Burlington permanent research plots in Forest Park (Dresner et al., 2017)

Analysis

I summarized the frequency distribution of ivy in each of the three datasets using histograms, median and IQR, and Shapiro-Wilk normality tests.

I calculated Moran's I (Moran, 1950) for ivy abundance for each of the three datasets to determine its global spatial autocorrelation-the overall extent to which its spatial distribution is self-influenced, whether more clustered $(I>0)$ or more distributed $(I<0)$ than would be expected at random. I also calculated a heatmap for 
each dataset using Getis-Ord Gi* (Getis \& Ord, 1992), weighted by inverse Euclidian distance, to illustrate clustering patterns.

At the landscape scale, I supplemented this statistic with Voronoi diagrams of ivy cover (median, interquartile range, clustering, and entropy), which allowed me to compare the values at the vegetation polygon centroids to their neighbors, giving a clearer sense of where local effects may be most pronounced and potentially revealing epicenters of the ivy invasion.

Results

Landscape Scale: Forest Park

At the landscape scale, the ivy cover class values (median $=$ trace, $\mathrm{IQR}=$ none to $1 \%-10 \%$ ) have a significantly negatively-skewed frequency distribution (ShapiroWilk normality test $\mathrm{W}=0.786, \mathrm{p}<0.0001$ ), with an apparent secondary mode at the 20\%-50\% cover class (Fig. 4).

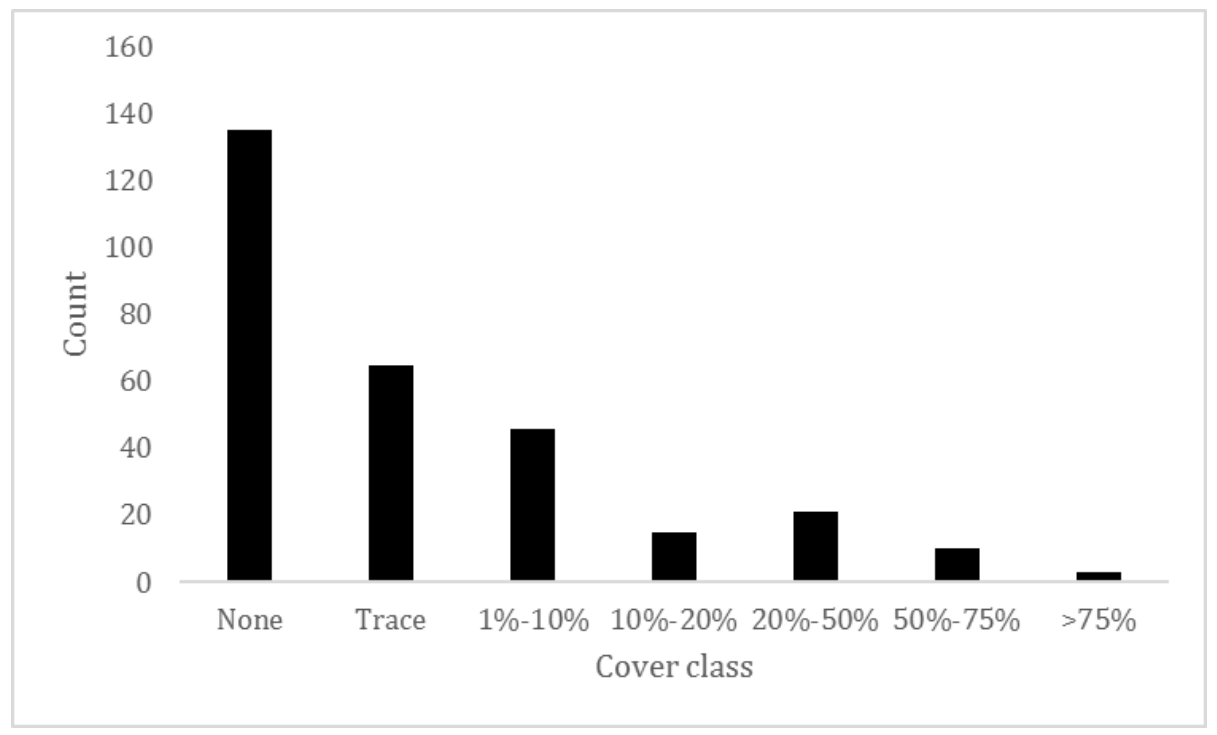

Figure 4: Frequency distribution of ivy by cover class across the Forest Park landscape. 
Ivy is unevenly distributed across Forest Park (Fig. 5). Ivy showed a fairly strong and highly significant clustering trend (Moran's $I=0.5544$, z-score $=15.006$, $\mathrm{p}<0.0001)$.

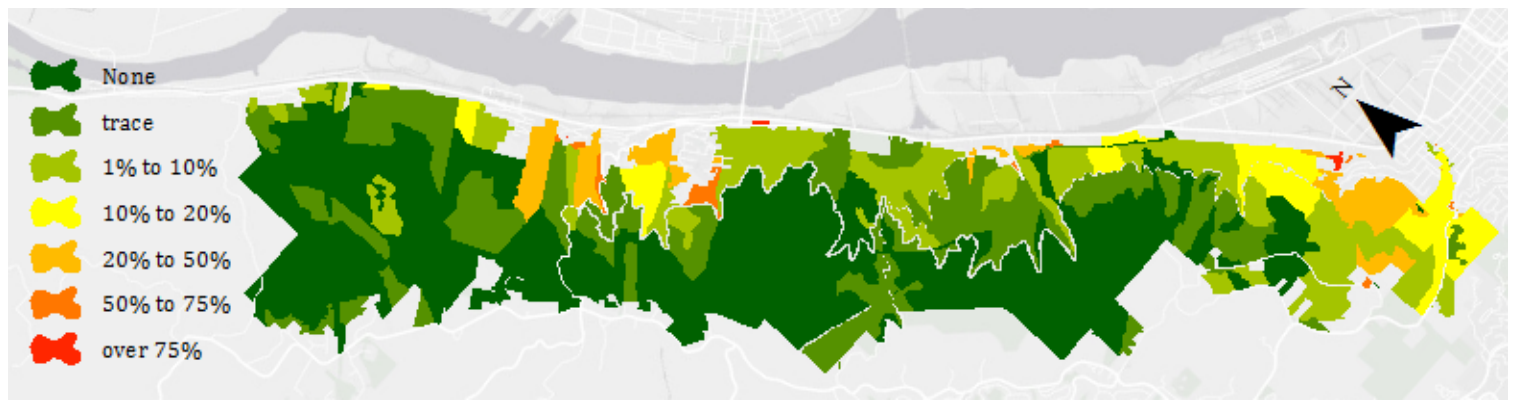

Figure 5: Spatial distribution of ivy by cover class across the Forest Park landscape.

There appear to be significant hotspots (Fig. 6) at several areas along the eastern edge of the park, as well as one near Holman Lane and NW 53 ${ }^{\text {rd }}$ Ave. 


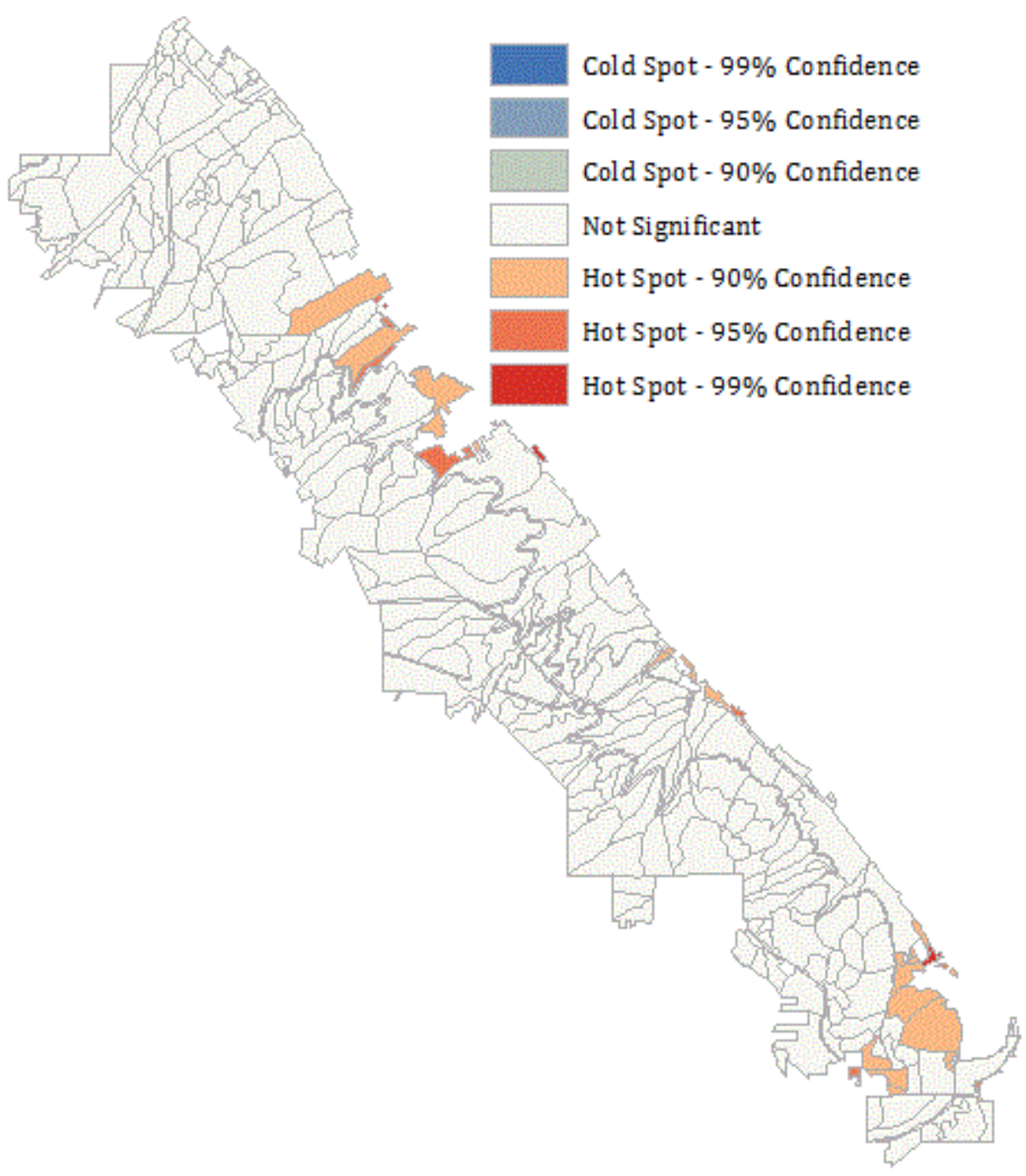

Figure 6: Hotspot (Getis-Ord Gi*) analysis results for the full landscape dataset 


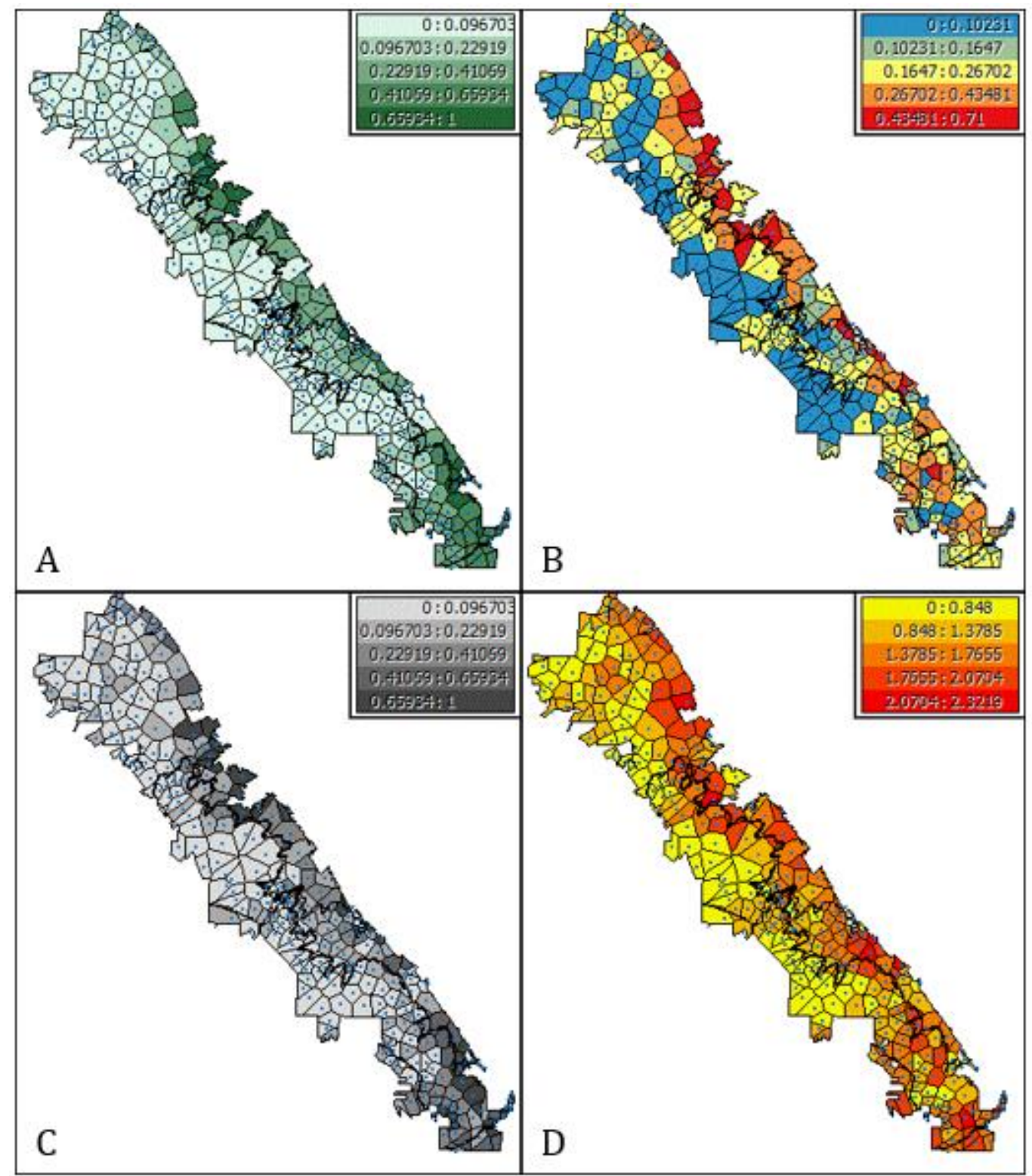

Figure 7: Voronoi diagrams of the landscape-scale spatial distribution of ivy (normalized values): (A) medians; (B) IQRs; (C) clustering; (D) entropy.

Voronoi diagrams (Fig. 7) indicate that, at the landscape scale, ivy tends to be both more generally abundant and more variable in the urban periphery area than in the park interior and rural periphery areas. Potential source populations (areas of high abundance and clustering surrounded by areas of high variance and entropy) 
are located around the mouth of Balch Creek, the south Leif Erikson Drive trailhead, Holman Lane off $53^{\text {rd }}$ Drive, the east outlet of Saltzman Road, the Springville Road neighborhood above NW Bridge Avenue, and lower Germantown Road.

Intermediate Scale: Balch Treatment Area

The ivy count values (median $=12, \mathrm{IQR}=1$ to 23.5 ) have a pronounced and significant negative skew (Shapiro-Wilk $\mathrm{W}=0.861, \mathrm{p}<0.0001$ ) in its frequency distribution, but not a steady decline across increasing abundance, with an apparent secondary mode around 25 hits per 35 counts (Fig. 8).

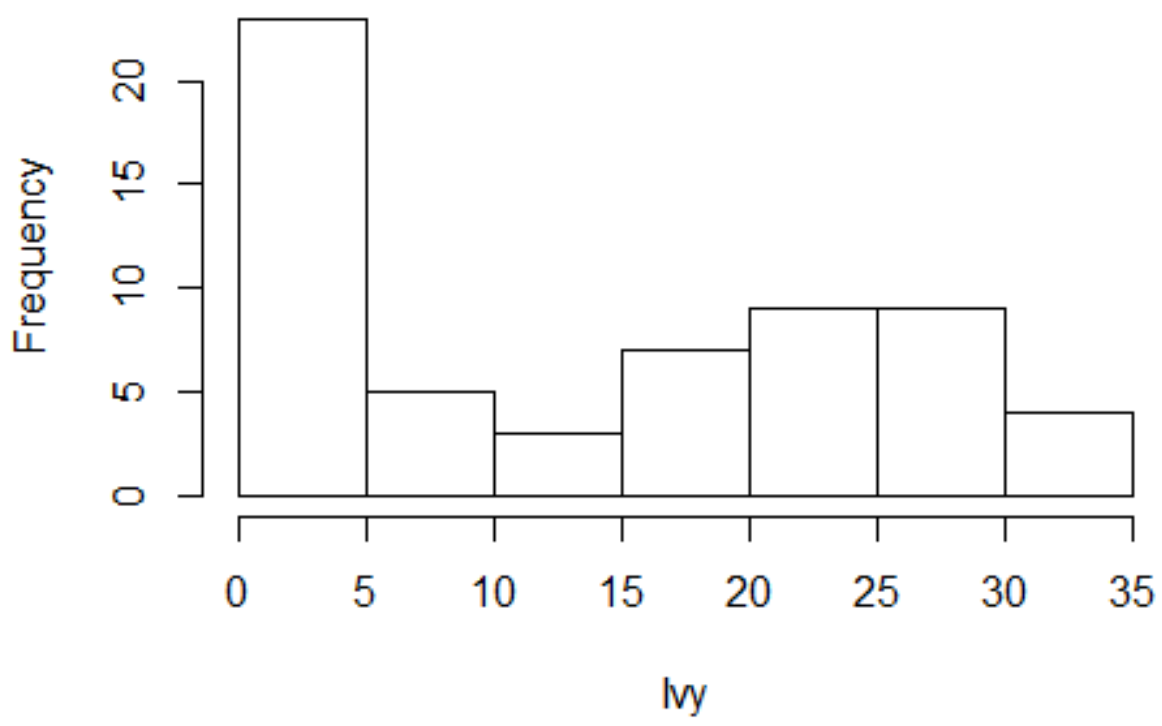

Figure 8: Histogram of ivy abundance in the Balch I UMP sites Ivy also has an uneven spatial distribution at the intermediate scale (Fig. 9). It is significantly clustered (Moran's $I=0.274$, z-score $=2.751, \mathrm{p}=0.0059$ ), but no significant hotspots were detected. 


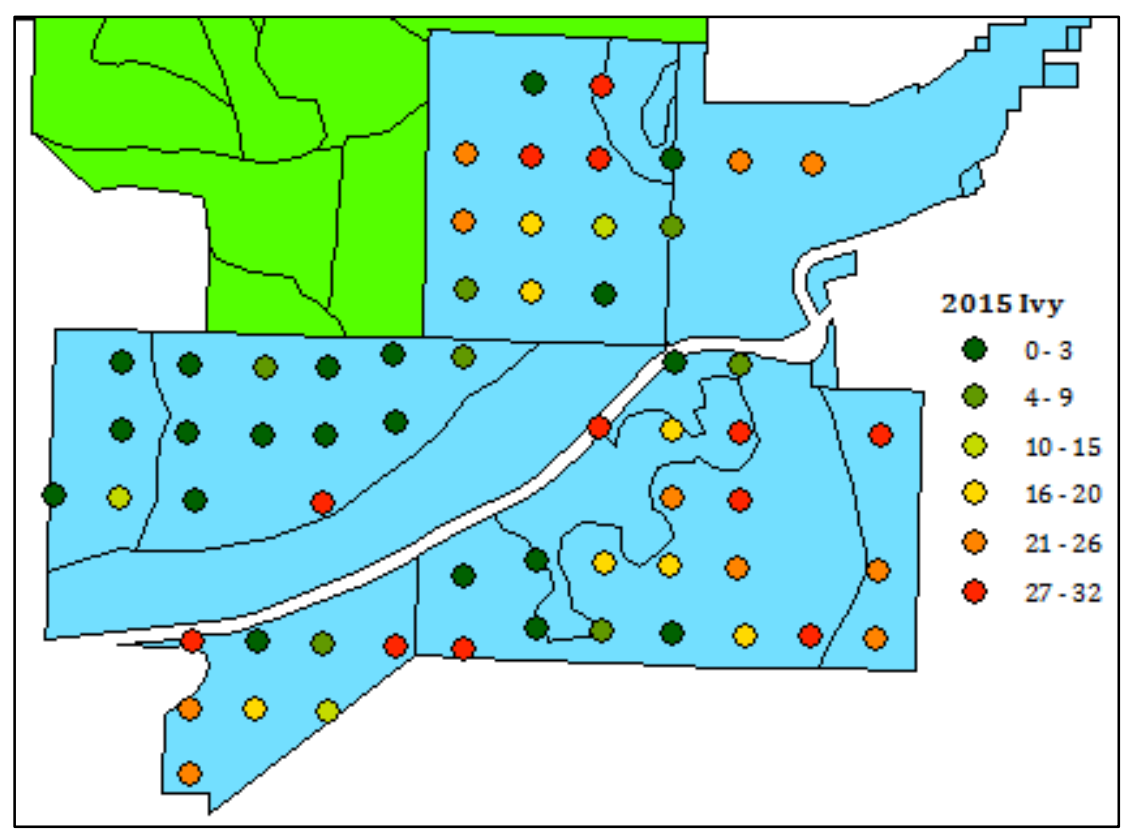

Figure 9: Distribution of ivy in Balch I Treatment Area

Site Scale: Balch Creek Research Plots

The frequency distribution of percent ivy cover (median $=10 \%, \mathrm{IQR}=0 \%$ to $75 \%$ ) at the site scale is significantly negatively skewed (Shapiro-Wilk normality test $\mathrm{W}=0.788, \mathrm{p}<0.0001)$, with a preponderance of 0 values and a slight secondary mode in the 70\%-100\% range (Fig. 10). 


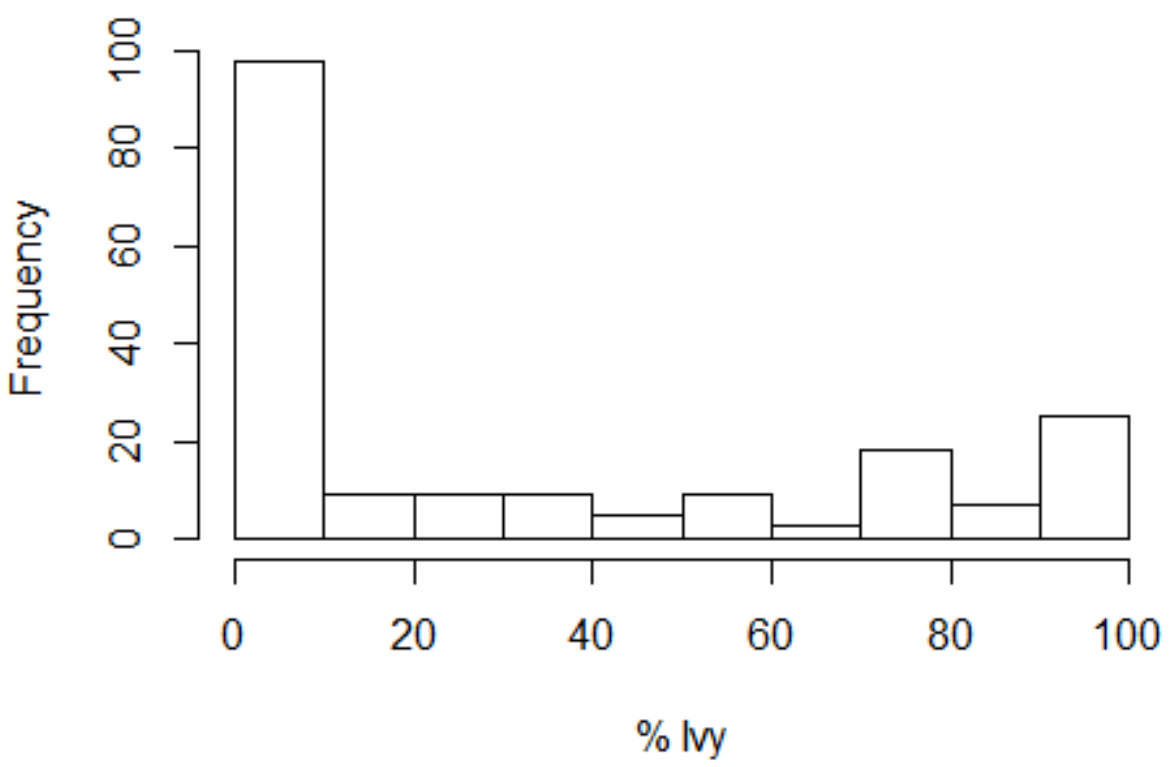

Figure 10: Histogram of ivy abundance in the combined Audubon, Coyote, and Balch permanent research plots

At the site scale, ivy shows some possible pattern in its distribution (Fig. 11, top). Ivy is significantly spatially autocorrelated in Balch (Moran's $I=0.460$, z-score $=4.210, \mathrm{p}<0.0001)$ and Coyote (Moran's $I=0.227$, z-score $=2.148, \mathrm{p}=0.032)$ but not in Audubon (Moran's $I=0.0919, \mathrm{z}$-score $=1.252, \mathrm{p}=0.21$ ), presumably due to its scarcity in that site. Hotspot analysis (Fig. 11, bottom) confirms this finding. 


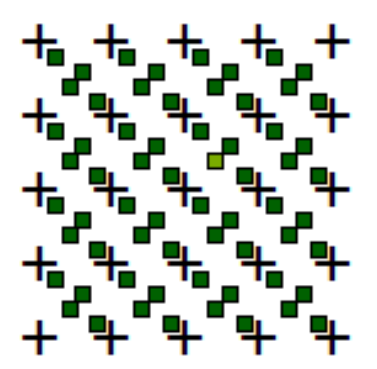

Audubon

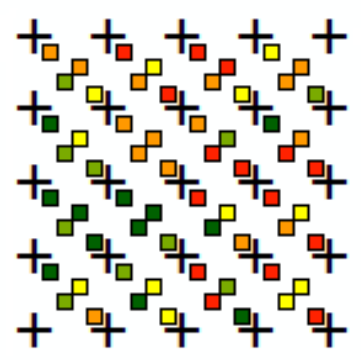

Coyote

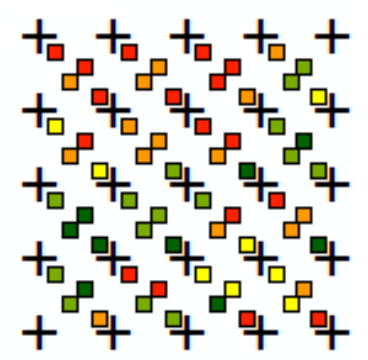

Balch

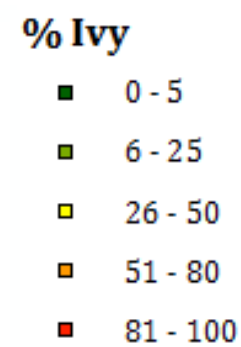

ㅁ $81-100$

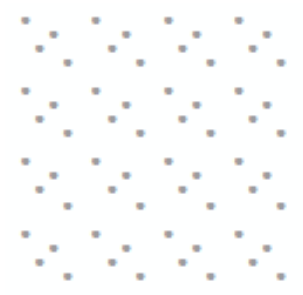

Audubon

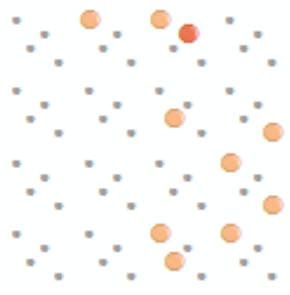

Coyote

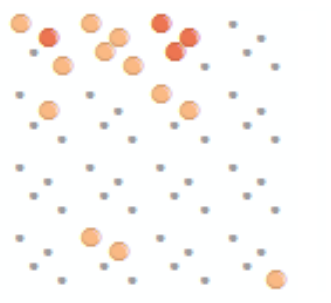

Balch
Cold Spot - 99\% Confidence

Cold Spot - 95\% Confidence

Cold Spot - 90\% Confidence

Not Significant

Hot Spot - 90\% Confidence

- Hot Spot-95\% Confidence

- Hot Spot - $99 \%$ Confidence

Figure 11: Spatial distribution (top) and hotspot analysis (bottom) of ivy cover in the three Balch Creek permanent research plots

Section 2: Environmental Predictors of Ivy

Question

What environmental factors are associated with the abundance of ivy in Forest Park at all scales?

Depending on cause-effect relationships, the conditions most associated with ivy abundance can be indicators of ecological vulnerability to ivy invasion and dominance, or reveal the consequences of ivy on the landscape. These both have implications for decisions about ivy management. I used the same ivy data from the distribution analysis along with predictor variables generated from the same or 
other datasets, and used correlation tests, ordination, and multiple regression to identify important relationships between ivy and its potential predictors.

Data

I complemented the three vegetation datasets with a variety of other data, including metrics of canopy, soil, topography, and landscape structure. Several of these variables (e.g., evergreen shrub abundance, \% interior) are testing previously described relationships, while others (e.g., slope, soil quality) are predictors which have not yet been studied in this system. However, usable data for other potential predictors, such as air pollution and soil nutrients, were not available.

\section{Landscape Scale: Forest Park}

I used the vegetation survey data discussed in Section 1 for the landscapescale analyses. Other variables were derived from a variety of publically-accessible GIS and remote sensing datasets (Table 2); in order to minimize temporal discontinuity between vegetation data and other predictors, I selected the archived data closest to 2004 whenever available. I conducted all geoprocessing and zonal statistics in ArcGIS 10.5 .

Table 2: Variables representing ivy abundance and its potential predictors at the landscape scale

\begin{tabular}{|l|l|l|l|}
\hline Variable & Source & Data type & Notes \\
\hline Ivy abundance & $\begin{array}{l}\text { (Vegetation Unit } \\
\text { Summaries for } \\
\text { Forest Park, } \\
\text { 2009) }\end{array}$ & $\begin{array}{l}\text { Inventory } \\
\text { survey }\end{array}$ & $\begin{array}{l}\text { Estimated as cover class } \\
\text { and converted to 0-7 } \\
\text { integer scale. }\end{array}$ \\
\hline $\begin{array}{l}\text { Shrub species } \\
\text { richness }\end{array}$ & $\begin{array}{l}\text { Vegetation Unit } \\
\text { Summaries for }\end{array}$ & $\begin{array}{l}\text { Inventory } \\
\text { survey }\end{array}$ & $\begin{array}{l}\text { Species richness not } \\
\text { expected to be affected by } \\
\text { ivy (Dlugosch, 2005). }\end{array}$ \\
\hline
\end{tabular}




\begin{tabular}{|c|c|c|c|}
\hline & $\begin{array}{l}\text { Forest Park, } \\
2009)\end{array}$ & & \\
\hline $\begin{array}{l}\text { Shrub sum cover } \\
\text { class }\end{array}$ & $\begin{array}{l}\text { (Vegetation Unit } \\
\text { Summaries for } \\
\text { Forest Park, } \\
\text { 2009) }\end{array}$ & $\begin{array}{l}\text { Inventory } \\
\text { survey }\end{array}$ & $\begin{array}{l}\text { Cover classes for all shrub } \\
\text { and small tree species } \\
\text { converted to 0-6 scale. } \\
\text { Shrub cover may facilitate } \\
\text { ivy spread by attracting } \\
\text { birds (Kollmann \& Grubb, } \\
\text { 1999). Overall shrub cover } \\
\text { expected to decline with } \\
\text { ivy (Dlugosch, 2005; } \\
\text { Hallett et al., 2017). }\end{array}$ \\
\hline $\begin{array}{l}\text { Shrub Simpson's } \\
\text { diversity by cover } \\
\text { class }\end{array}$ & $\begin{array}{l}\text { (Vegetation Unit } \\
\text { Summaries for } \\
\text { Forest Park, } \\
\text { 2009) }\end{array}$ & $\begin{array}{l}\text { Inventory } \\
\text { survey }\end{array}$ & \\
\hline $\begin{array}{l}\text { Shrub \% } \\
\text { evergreen by } \\
\text { cover class }\end{array}$ & $\begin{array}{l}\text { (Vegetation Unit } \\
\text { Summaries for } \\
\text { Forest Park, } \\
2009 \text { ) }\end{array}$ & $\begin{array}{l}\text { Inventory } \\
\text { survey }\end{array}$ & $\begin{array}{l}\text { Evergreen shrubs more } \\
\text { likely to compete } \\
\text { seasonally for resources } \\
\text { with ivy (Hallett et al., } \\
\text { 2017); salal (Gaultheria } \\
\text { shallon) excluded from } \\
\text { ivy-infested areas in an } \\
\text { urban forest in Vancouver, } \\
\text { BC (Quinn \& Best, 2002); } \\
\text { decline in evergreen } \\
\text { shrubs might release } \\
\text { deciduous competitors } \\
\text { (Hallett et al., 2017). }\end{array}$ \\
\hline $\begin{array}{l}\text { Shrub \% tall }(>3 \mathrm{~m} \\
\text { typical height) by } \\
\text { cover class }\end{array}$ & $\begin{array}{l}\text { (Vegetation Unit } \\
\text { Summaries for } \\
\text { Forest Park, } \\
\text { 2009) }\end{array}$ & $\begin{array}{l}\text { Inventory } \\
\text { survey }\end{array}$ & $\begin{array}{l}\text { Tall shrubs, esp. with } \\
\text { multiple short-lived stems } \\
\text { (e.g., Corylus), may be less } \\
\text { likely to have ivy invade } \\
\text { their canopies (Madrigal- } \\
\text { Gonzalez, Rios, Aragon, \& } \\
\text { Gianoli, 2018). }\end{array}$ \\
\hline Mean soil quality & (Green, 1983) & Soil survey & $\begin{array}{l}\text { A classification based on } \\
\text { Green (1983) and an } \\
\text { associated GIS layer. Local } \\
\text { soils clearly fall into four } \\
\text { distinct categories, based } \\
\text { on soil depth and degree } \\
\text { of erosion/disturbance. }\end{array}$ \\
\hline
\end{tabular}




\begin{tabular}{|c|c|c|c|}
\hline $\begin{array}{l}\text { Mean } \\
\text { topographical } \\
\text { wetness index } \\
\text { (TWI) }\end{array}$ & $\begin{array}{l}\text { (Sando, Olsen, } \\
\text { Kaiser, Haluska, \& } \\
\text { Hockman-Wert, } \\
\text { 2018) }\end{array}$ & $\begin{array}{l}\text { Digital } \\
\text { elevation } \\
\text { model } \\
\text { (DEM) } \\
\text { derivative }\end{array}$ & $\begin{array}{l}\text { Considered a good proxy } \\
\text { for soil moisture for small, } \\
\text { steep catchments. Ivy is } \\
\text { often associated with } \\
\text { riparian areas (Ramsey, } \\
\text { 2005), but it may have a } \\
\text { quadratic relationship to } \\
\text { TWI (Chance et al., 2016). }\end{array}$ \\
\hline \% canopy & $\begin{array}{l}\text { (Vegetation Unit } \\
\text { Summaries for } \\
\text { Forest Park, } \\
\text { 2009) }\end{array}$ & $\begin{array}{l}\text { Inventory } \\
\text { survey }\end{array}$ & $\begin{array}{l}\text { Estimated to nearest } 5 \% \text {. } \\
\text { Deepest shade may reduce } \\
\text { ivy growth (Sack \& Grubb, } \\
\text { 2002). }\end{array}$ \\
\hline $\begin{array}{l}\text { Mean canopy } \\
\text { height }\end{array}$ & $\begin{array}{l}\text { (OLC Metro } 2014 \\
\text { Lidar Project, } \\
2014)\end{array}$ & LiDAR & $\begin{array}{l}\text { Highest hit minus bare } \\
\text { surface; } 1 \mathrm{~m} \text { resolution. }\end{array}$ \\
\hline SD canopy height & $\begin{array}{l}\text { (OLC Metro } 2014 \\
\text { Lidar Project, } \\
2014)\end{array}$ & LiDAR & $\begin{array}{l}\text { Canopy variance has been } \\
\text { found to exert a greater } \\
\text { influence on understory } \\
\text { composition than total } \\
\text { canopy in our region (Van } \\
\text { Pelt \& Franklin, 2000). }\end{array}$ \\
\hline $\begin{array}{l}\text { Canopy evergreen } \\
\text { to deciduous ratio }\end{array}$ & $\begin{array}{l}\text { (Canopy 2007, } \\
2016)\end{array}$ & $\begin{array}{l}\text { Remote } \\
\text { sensing } \\
\text { derivative }\end{array}$ & $\begin{array}{l}\text { Based on LiDAR and aerial } \\
\text { imagery (evg = 1, dec = 2); } \\
\text { est. accuracy } \sim 88 \% \text {. } \\
\text { Seasonal pattern of ivy } \\
\text { growth suggests it might } \\
\text { be more abundant under } \\
\text { deciduous canopy } \\
\text { (Leuzinger et al., 2011), } \\
\text { but has been correlated } \\
\text { with evergreen canopy in } \\
\text { urban landscapes (Chance } \\
\text { et al., 2016). }\end{array}$ \\
\hline Mean slope & $\begin{array}{l}\text { (OLC Metro } 2014 \\
\text { Lidar Project, } \\
2014)\end{array}$ & LiDAR & $\begin{array}{l}\text { Ivy may be associated } \\
\text { with intermediate }(5 \%- \\
10 \% \text { ) slopes (Chance et al., } \\
2016) \text {. }\end{array}$ \\
\hline SD slope & $\begin{array}{l}\text { (OLC Metro } 2014 \\
\text { Lidar Project, } \\
2014)\end{array}$ & LiDAR & \\
\hline Road/trail density & $\begin{array}{l}\text { (Roads (Regional } \\
\text { Land Information } \\
\text { System dataset), }\end{array}$ & $\begin{array}{l}\text { GIS feature } \\
\text { classes }\end{array}$ & $\begin{array}{l}\text { Topographic disturbance } \\
\text { buffers based on field } \\
\text { measurements: roads }\end{array}$ \\
\hline
\end{tabular}




\begin{tabular}{|c|c|c|c|}
\hline & $\begin{array}{l}\text { 2011; Trails } \\
\text { (Regional Land } \\
\text { Information } \\
\text { System dataset), } \\
\text { 2011) }\end{array}$ & & $\begin{array}{l}(11 \mathrm{~m}) \text {, trails } 15+(10 \mathrm{~m}), \\
\text { trails } 10-14(8 \mathrm{~m}) \text {, trails } 6- \\
9(6 \mathrm{~m}) \text {, trails } 1-5(2 \mathrm{~m}) .\end{array}$ \\
\hline \% interior & $\begin{array}{l}\text { (Vegetation } \\
\text { Mapping Project, } \\
\text { 2011) }\end{array}$ & $\begin{array}{l}\text { GIS feature } \\
\text { class }\end{array}$ & $\begin{array}{l}\text { PP\&R defines "interior } \\
\text { forest" as }>35 \text { acres and } \\
300 \mathrm{ft} \text {. from a canopy gap. } \\
\text { Source data based on } \\
2000 \text { aerial imagery. } 74 \% \\
\text { of study area "interior". } \\
\text { Liana abundance may } \\
\text { decrease with edge } \\
\text { distance in temperate } \\
\text { deciduous forests (Londre } \\
\text { \& Schnitzer, 2006). }\end{array}$ \\
\hline $\begin{array}{l}\text { Spatial } \\
\text { dependency }\end{array}$ & $\begin{array}{l}\text { (Vegetation Unit } \\
\text { Summaries for } \\
\text { Forest Park, } \\
\text { 2009) }\end{array}$ & $\begin{array}{l}\text { Inventory } \\
\text { survey }\end{array}$ & $\begin{array}{l}\text { Calculated as the mean of } \\
\text { the ivy cover class of the } \\
\text { four nearest (Euclidian } \\
\text { distance between } \\
\text { centroids) polygons. }\end{array}$ \\
\hline
\end{tabular}

I used a stratified random sample of 40 non-contiguous vegetation units (20 with ivy significantly present, 20 with "none" or "trace") from the landscape data for statistical analysis (Fig. 12). 


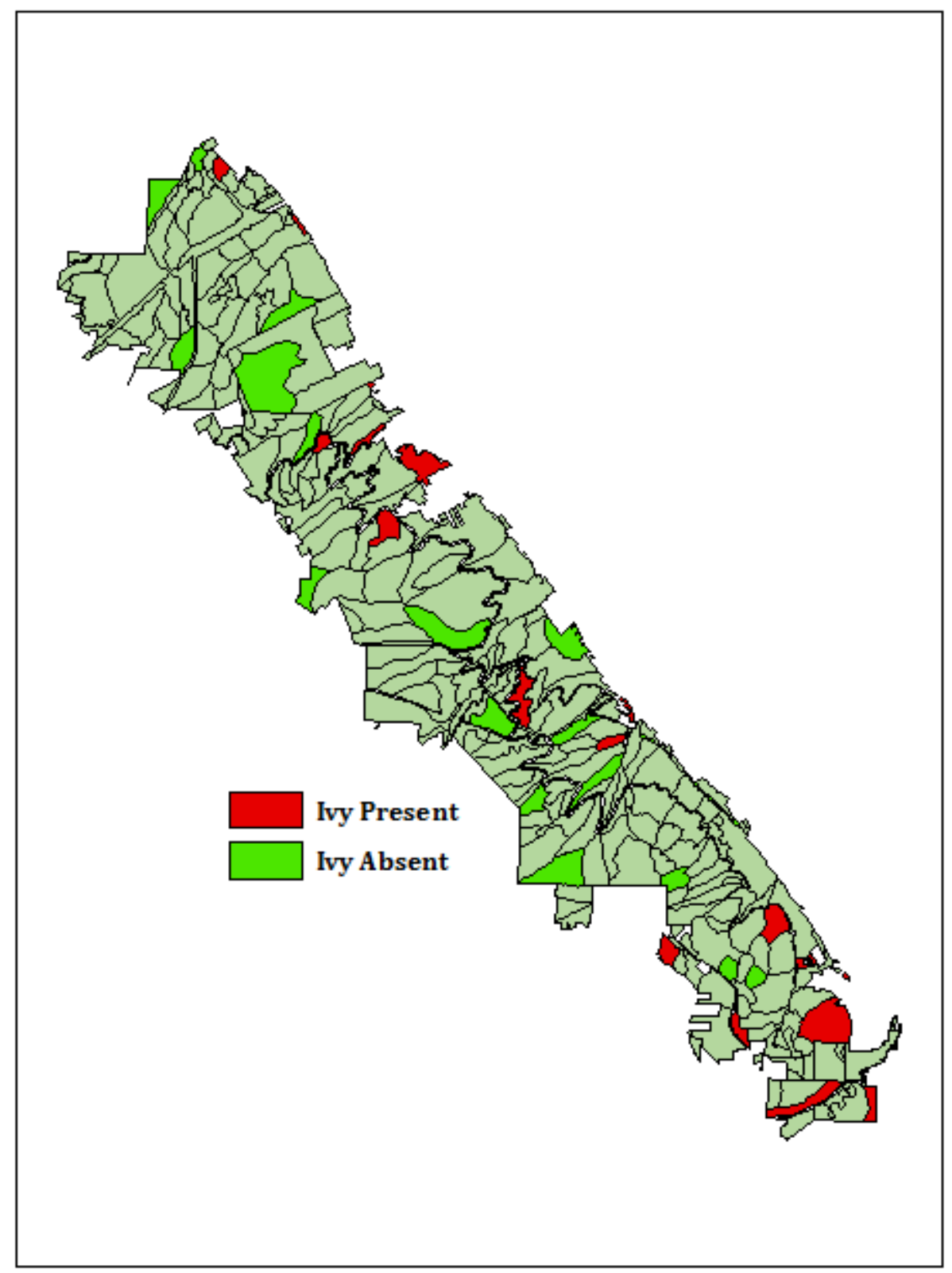

Figure 12: Forest Park vegetation polygons $(\mathrm{n}=295)$, highlighting the subsample $(n=40)$ used for statistical analysis. "Ivy Present" $(n=20)$ are cover classes of $1 \%$ $10 \%$ or above; "Ivy Absent" (n=20) are cover classes of "none" or "trace".

\section{Intermediate Scale: Balch Treatment Area}

The 2015 Balch I UMP data included only vegetation counts; other attributes intended to be part of the protocol, including woody debris and tree density, were 
not available for this portion of the data. Furthermore, 17 plots out of the 76 appeared not to have been surveyed at that time, and transect bearings were not recorded for any plots. I removed the unsurveyed plots from analysis, along with plots with fewer than 3 neighbors in order to ensure the accuracy of my spatial dependency metric, for a final sample size of 55. I calculated spatial dependency as the inverse distance weighted (IDW) mean of ivy (ivy count / scaled Euclidian distance) in plots within 150m (in effect, queen's case proximity). I derived rasterbased variables as zonal statistics within $10 \mathrm{~m}$ buffers around each sampled point due to the difficulty of accurately reconstructing transects. Several variables of interest, including canopy density and soil metrics, were not available at an appropriate spatial resolution. All variables I used are described in Table 3.

Table 3: Variables representing ivy abundance and its potential predictors at the intermediate scale

\begin{tabular}{|l|l|l|l|}
\hline Variable & Source & Data type & Notes \\
\hline Ivy & $\begin{array}{l}\text { (Forest Park } \\
\text { Conservancy et al., } \\
2016)\end{array}$ & Pole-point count & $\begin{array}{l}\text { Sum of HEHE + } \\
\text { HEHI counts. }\end{array}$ \\
\hline $\begin{array}{l}\text { Shrub abundance } \\
\text { total) }\end{array}$ & $\begin{array}{l}\text { (Forest Park } \\
\text { Conservancy et al., } \\
2016)\end{array}$ & Pole-point count & $\begin{array}{l}\text { Sum of counts for } \\
\text { all woody species. }\end{array}$ \\
\hline Shrub richness & $\begin{array}{l}\text { (Forest Park } \\
\text { Conservancy et al., } \\
\text { 2016) }\end{array}$ & Pole-point count & \\
\hline $\begin{array}{l}\text { Shrub Simpson's } \\
\text { diversity }\end{array}$ & $\begin{array}{l}\text { (Forest Park } \\
\text { Conservancy et al., } \\
\text { 2016) }\end{array}$ & Pole-point count & \\
\hline $\begin{array}{l}\text { \% abundance of } \\
\text { tall }>3 \text { m typical } \\
\text { height) shrub spp. }\end{array}$ & $\begin{array}{l}\text { (Forest Park } \\
\text { Conservancy et al., } \\
\text { 2016) }\end{array}$ & Pole-point count & \\
\hline
\end{tabular}




\begin{tabular}{|l|l|l|l|}
\hline $\begin{array}{l}\text { \% abundance of } \\
\text { evergreen shrub } \\
\text { spp. }\end{array}$ & $\begin{array}{l}\text { (Forest Park } \\
\text { Conservancy et al., } \\
\text { 2016) }\end{array}$ & Pole-point count & \\
\hline Mean slope & $\begin{array}{l}\text { (OLC Metro 2014 } \\
\text { Lidar Project, } \\
\text { 2014) }\end{array}$ & LiDAR & \\
\hline SD slope & $\begin{array}{l}\text { (OLC Metro 2014 } \\
\text { Lidar Project, } \\
\text { 2014) }\end{array}$ & LiDAR & \\
\hline TWI & $\begin{array}{l}\text { (Sando et al., } \\
\text { 2018) }\end{array}$ & LiDAR & \\
\hline $\begin{array}{l}\text { Mean canopy } \\
\text { height }\end{array}$ & $\begin{array}{l}\text { OLC Metro 2014 } \\
\text { Lidar Project, } \\
\text { 2014) }\end{array}$ & LiDAR & \\
\hline SD canopy height & $\begin{array}{l}\text { (OLC Metro 2014 } \\
\text { Lidar Project, } \\
\text { 2014) }\end{array}$ & LiDAR & \\
\hline $\begin{array}{l}\text { Canopy con/dec } \\
\text { ratio }\end{array}$ & $\begin{array}{l}\text { (Canopy 2007, } \\
\text { 2016) }\end{array}$ & $\begin{array}{l}\text { Remote sensing } \\
\text { derivative }\end{array}$ & \\
\hline $\begin{array}{l}\text { Proximity to road } \\
\text { or trail }\end{array}$ & $\begin{array}{l}\text { (Trails (Regional } \\
\text { Land Information } \\
\text { System dataset), } \\
\text { 2011) }\end{array}$ & GIS feature class & $\begin{array}{l}\text { Calculated using } \\
\text { Near tool in } \\
\text { ArcGIS 10.5. }\end{array}$ \\
\hline $\begin{array}{l}\text { Spatial } \\
\text { dependency }\end{array}$ & $\begin{array}{l}\text { (Forest Park } \\
\text { Conservancy et al., } \\
\text { 2016) }\end{array}$ & Pole-point count & $\begin{array}{l}\text { Mean of IDW ivy } \\
\text { values at points } \\
\text { within 150m } \\
\text { radius. }\end{array}$ \\
\hline
\end{tabular}

Site Scale: Balch Creek Research Plots

The permanent research plots have associated data for several other environmental variables from past research, including soil properties by grid square (Addessi, 2017; Copp, 2014) and shrub transect surveys by meters of cover by species per $25 \mathrm{~m}$ segment (Dresner, n.d.); four plots also have canopy and dead biomass measurements (Addessi, 2017). Three plots in the Balch Creek Treatment Area (Balch and Coyote, two highly ivy-infested sites, and Audubon, a site with little 
ivy cover) had several variables available for analysis (Table 4), though again data on factors such as air pollution have not been collected for these sites, and soil depth had been measured for only Balch and Audubon and was omitted from analysis. My sampling design also precluded a meaningful spatial dependency metric at this scale.

Table 4: Variables representing ivy abundance and its potential predictors at the site scale

\begin{tabular}{|c|c|c|c|}
\hline Variable & Source & Data type & Notes \\
\hline Ivy abundance & $\begin{array}{l}\text { (Copp, } \\
\text { 2014) }\end{array}$ & $\begin{array}{l}\text { Microplot } \\
\text { survey }\end{array}$ & $\begin{array}{l}\text { Each segment value is mean of } 4 \\
\text { nearest microplots. }\end{array}$ \\
\hline $\begin{array}{l}\text { Shrub species } \\
\text { richness }\end{array}$ & $\begin{array}{l}\text { (Dresner, } \\
\text { McDonald, } \\
\text { \& Addessi, } \\
\text { n.d.) }\end{array}$ & $\begin{array}{l}\text { Transect } \\
\text { survey }\end{array}$ & \\
\hline $\begin{array}{l}\text { Shrub abundance } \\
\text { (total) }\end{array}$ & $\begin{array}{l}\text { (Dresner et } \\
\text { al., n.d.) }\end{array}$ & $\begin{array}{l}\text { Transect } \\
\text { survey }\end{array}$ & $\begin{array}{l}\text { Measured as meters of cover by } \\
\text { species per } 25 \mathrm{~m} \text { segment. }\end{array}$ \\
\hline $\begin{array}{l}\% \text { abundance of } \\
\text { tall ( }>3 \mathrm{~m} \text { typical } \\
\text { height) shrub spp. }\end{array}$ & $\begin{array}{l}\text { (Dresner et } \\
\text { al., n.d.) }\end{array}$ & $\begin{array}{l}\text { Transect } \\
\text { survey }\end{array}$ & \\
\hline $\begin{array}{l}\text { \% abundance of } \\
\text { evergreen shrub } \\
\text { spp. }\end{array}$ & $\begin{array}{l}\text { (Dresner et } \\
\text { al., n.d.) }\end{array}$ & $\begin{array}{l}\text { Transect } \\
\text { survey }\end{array}$ & \\
\hline Mean slope & $\begin{array}{l}\text { (OLC Metro } \\
\text { 2014 Lidar } \\
\text { Project, } \\
\text { 2014) }\end{array}$ & LiDAR & $\begin{array}{l}\text { Calculated by interpolation of } \\
\text { sample segments onto } 1 \mathrm{~m} \text { DEM } \\
\text { in ArcGIS. }\end{array}$ \\
\hline $\begin{array}{l}\text { Mean canopy } \\
\text { height }\end{array}$ & $\begin{array}{l}\text { (Addessi, } \\
\text { 2017) }\end{array}$ & $\begin{array}{l}\text { Macroplot } \\
\text { survey }\end{array}$ & $\begin{array}{l}\text { Mean height of all trees within } \\
12.5 \mathrm{~m} \text { rectangular buffer of each } \\
\text { transect segment. }\end{array}$ \\
\hline SD canopy height & $\begin{array}{l}\text { (Addessi, } \\
\text { 2017) }\end{array}$ & $\begin{array}{l}\text { Macroplot } \\
\text { survey }\end{array}$ & \\
\hline Tree basal area & $\begin{array}{l}\text { (Addessi, } \\
\text { 2017) }\end{array}$ & $\begin{array}{l}\text { Macroplot } \\
\text { survey }\end{array}$ & $\begin{array}{l}\text { Large trees tend to have higher } \\
\text { liana densities in invaded } \\
\text { temperate forests (Leicht-Young, } \\
\text { Pavlovic, Frohnapple, \& Grundel, } \\
\text { 2010). }\end{array}$ \\
\hline
\end{tabular}




\begin{tabular}{|c|c|c|c|}
\hline Tree stem count & $\begin{array}{l}\text { (Addessi, } \\
\text { 2017) }\end{array}$ & $\begin{array}{l}\text { Macroplot } \\
\text { survey }\end{array}$ & $\begin{array}{l}\text { Isolated trees are more likely to } \\
\text { be invaded than dense stands in } \\
\text { ivy's native range (Castagneri, } \\
\text { Garbarino, \& Nola, 2013). }\end{array}$ \\
\hline $\begin{array}{l}\text { \% coniferous by } \\
\text { basal area }\end{array}$ & $\begin{array}{l}\text { (Addessi, } \\
\text { 2017) }\end{array}$ & $\begin{array}{l}\text { Macroplot } \\
\text { survey }\end{array}$ & $\begin{array}{l}\text { Basal area closest available proxy } \\
\text { to canopy area. }\end{array}$ \\
\hline $\begin{array}{l}\% \text { coniferous by } \\
\text { stem count }\end{array}$ & $\begin{array}{l}\text { (Addessi, } \\
\text { 2017) }\end{array}$ & $\begin{array}{l}\text { Macroplot } \\
\text { survey }\end{array}$ & \\
\hline Soil moisture & $\begin{array}{l}\text { (Copp, } \\
\text { 2014) }\end{array}$ & $\begin{array}{l}\text { Microplot } \\
\text { survey }\end{array}$ & $\begin{array}{l}\text { Estimated; variation more } \\
\text { important than actual values due } \\
\text { to seasonality of measurements. }\end{array}$ \\
\hline Soil pH & $\begin{array}{l}\text { (Addessi, } \\
\text { 2017) }\end{array}$ & $\begin{array}{l}\text { Microplot } \\
\text { survey }\end{array}$ & $\begin{array}{l}\text { Ivy-dominated sites found to } \\
\text { have higher pH (Heckman, 2007) }\end{array}$ \\
\hline $\begin{array}{l}\text { Estimated soil } \\
\text { organic matter }\end{array}$ & $\begin{array}{l}\text { (Addessi, } \\
\text { 2017) }\end{array}$ & $\begin{array}{l}\text { Microplot } \\
\text { survey }\end{array}$ & $\begin{array}{l}\text { Ivy-dominated sites found to } \\
\text { have less leaf litter (Heckman, } \\
\text { 2007). }\end{array}$ \\
\hline Snag abundance & $\begin{array}{l}\text { (Addessi, } \\
\text { 2017) }\end{array}$ & $\begin{array}{l}\text { Macroplot } \\
\text { survey }\end{array}$ & $\begin{array}{l}\text { Deficient dead biomass often } \\
\text { indicates ecological debt from } \\
\text { disturbance history such as } \\
\text { logging or fire (Abrego \& Salcedo, } \\
\text { 2013). }\end{array}$ \\
\hline CWD abundance & $\begin{array}{l}\text { (Addessi, } \\
\text { 2017) }\end{array}$ & $\begin{array}{l}\text { Macroplot } \\
\text { survey }\end{array}$ & \\
\hline
\end{tabular}

Since these data existed in different sample units, I subsampled each dataset into a staggered transect segment structure (Fig. 13) to create a common reference without any redundancy. Each plot thus had a sample size of 6. I added slope as a variable by interpolating the sample transect segments as shapefiles onto a $1 \mathrm{~m}$ slope raster in ArcGIS and calculating the mean for each segment. 


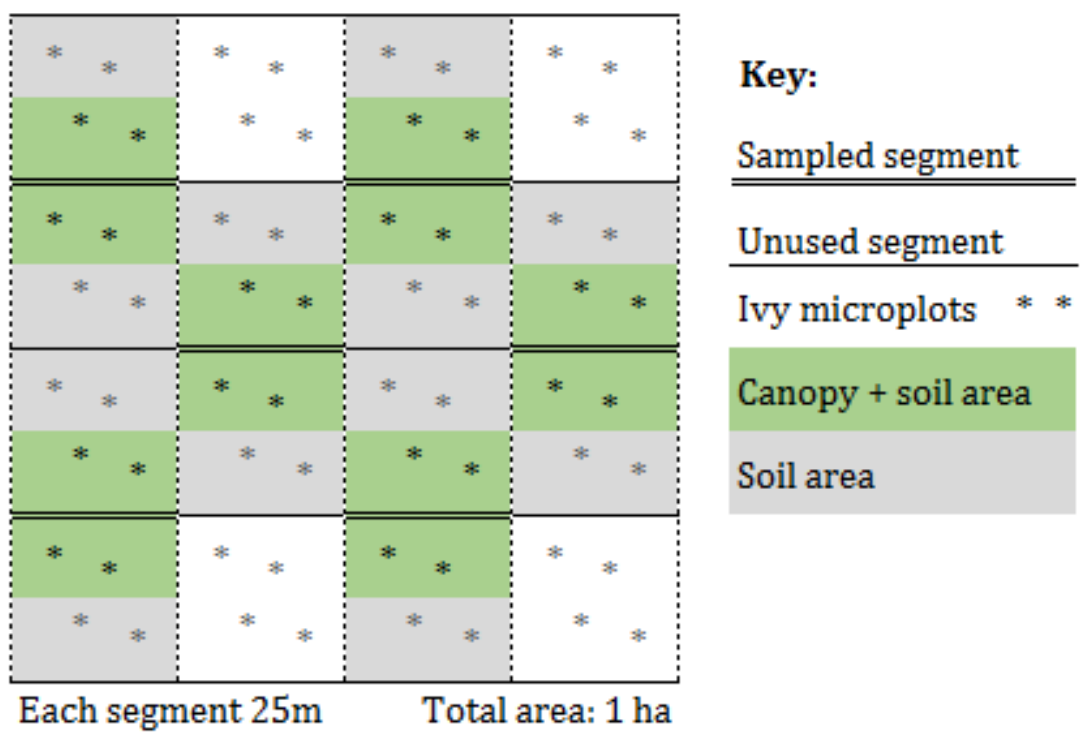

Figure 13: Site-scale predictors sampling design.

Analysis

Landscape Scale: Forest Park

I started by calculating the Spearman rank correlation between ivy and all predictor variables to identify potentially important relationships and their directions. After normalizing all my variables to their maximum values in order to scale different units together, I analyzed them using Nonmetric Multidimensional Scaling (NMDS) ordination (R: vegan package, metaMDS function; parameters: 2 axes, 20 starts, Euclidian distance) (Kruskal, 1964; Minchin, 1987). The metaMDS function performs a specified number of random starts to converge on a stable solution and generates both "site" (row/replicate) and "species" (column/variable) ordinations. This allowed me to identify any variables ("species"), including ivy abundance, with strong trends; I also displayed "sites" with a gradient of ivy 
abundance to help visualize that variable's apparent influence, if any, on the model system. I then used an ordination fitting function (R: vegan package, envfit function) to determine which environmental variables had the greatest influence on all other variables in the dataset. Finally, I used Random Forest (RF) regression in R (Breiman, 2001; Liaw \& Wiener, 2002) to determine which other variables were most predictive of ivy cover class. I did so first using all predictors and then dropping the least influential variable (with the lowest increased node purity) stepwise until I found the strongest reduced model or reached three variables, the functional minimum in RF. The model strength was expressed as a percentage of explained variance, derived from the mean of squared residuals (MSR), number of variables, and sample size.

Intermediate Scale: Balch Treatment Area

I again normalized my variables to their maximum values when necessary and used NMDS ordination and model-fitting with the same parameters as for the landscape scale. I used RF regression, starting with all predictors and reducing the model stepwise, to determine which variables were most predictive of ivy abundance.

Site Scale: Balch Creek Research Plots

Having normalized my variables to their maximum values as needed, I entered them into the same NMDS ordination and model fitting functions as for the previous scales. Finally, I used RF regression with stepwise model reduction to determine the most significant predictors of ivy abundance. 
Results

Landscape Scale: Forest Park

At the landscape scale, ivy has a very strong positive correlation with its own spatial dependency, as well as positive correlations with slope variance and shrub diversity and strong negative correlations with interiority and soil quality (Table 5).

Table 5: Spearman rank correlation values between ivy and environmental predictors at the landscape scale. P-values are estimates due to tie ivy scores.

\begin{tabular}{|l|l|l|}
\hline Predictor variable & Spearman-rank R-value & Estimated p-value \\
\hline Spatial dependency of ivy & 0.810 & $<0.0001^{* * *}$ \\
\hline Soil & -0.507 & $0.009^{* *}$ \\
\hline Interiority & -0.478 & $0.002^{* *}$ \\
\hline SD slope & 0.367 & $0.020^{*}$ \\
\hline Shrub Simpson's D & 0.365 & $0.021^{*}$ \\
\hline SD canopy height & 0.285 & 0.075 \\
\hline \% canopy & -0.101 & 0.533 \\
\hline Road/trail density & -0.082 & 0.617 \\
\hline Shrub \% evergreen & 0.076 & 0.642 \\
\hline Shrub richness & 0.047 & 0.772 \\
\hline TWI & -0.043 & 0.794 \\
\hline Mean slope & 0.040 & 0.808 \\
\hline Shrub \% tall & -0.031 & 0.848 \\
\hline Con/dec ratio & 0.024 & 0.884 \\
\hline Shrub abundance & -0.015 & 0.927 \\
\hline Mean canopy height & -0.0003 & 0.999 \\
\hline
\end{tabular}

NMDS ordination (2 axes, Euclidian distance, 20 runs) produced a viable model with a non-metric $\mathrm{R}^{2}$ of 0.968 and a model stress of 0.1782 (Fig. 14) 


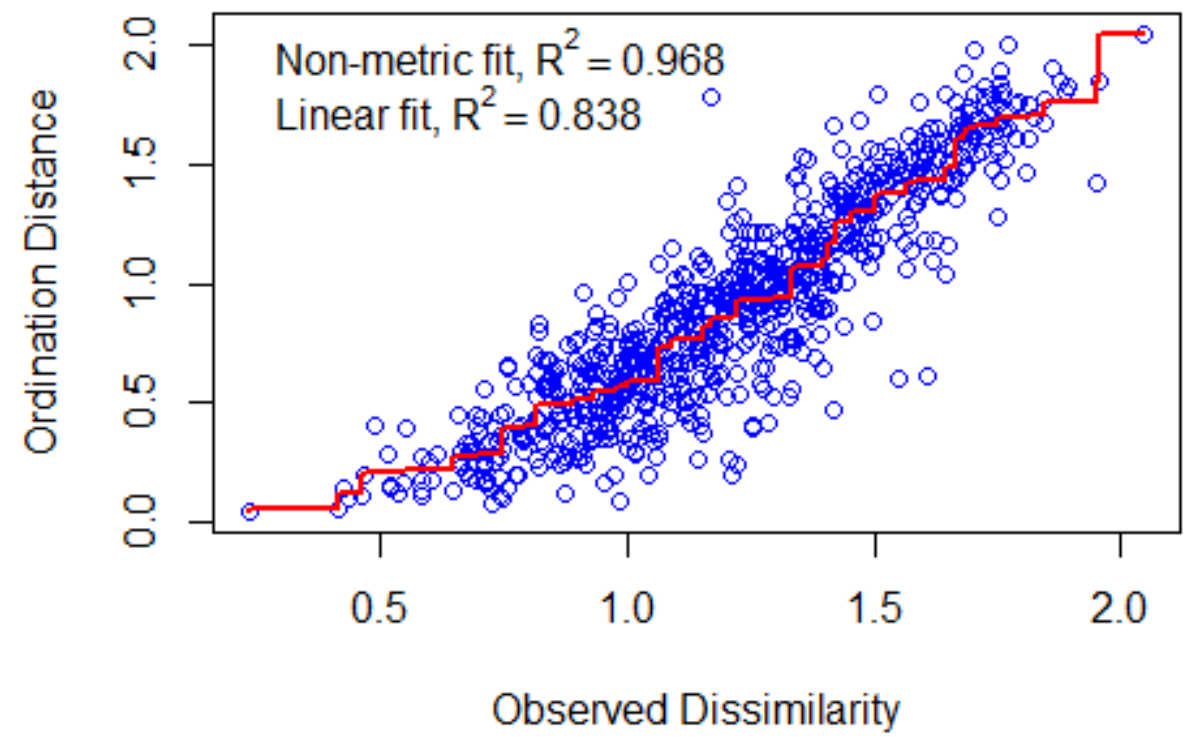

Figure 14: Stressplot of the landscape-scale NMDS ordination of environmental variables ( 2 axes, 20 runs). A high non-metric fit $\left(\mathrm{R}^{2}=0.968\right)$ means the ordination is a strong fit to the data, assuming monotonic but not linear relationships among variables, and a low model stress (stress $=0.1782$ ) means there were enough variables for the number of axes to explain most of the variance without overfitting the model.

Ordination by sites displayed a fairly pronounced gradient of ivy abundance toward quadrant III (Fig. 15). 


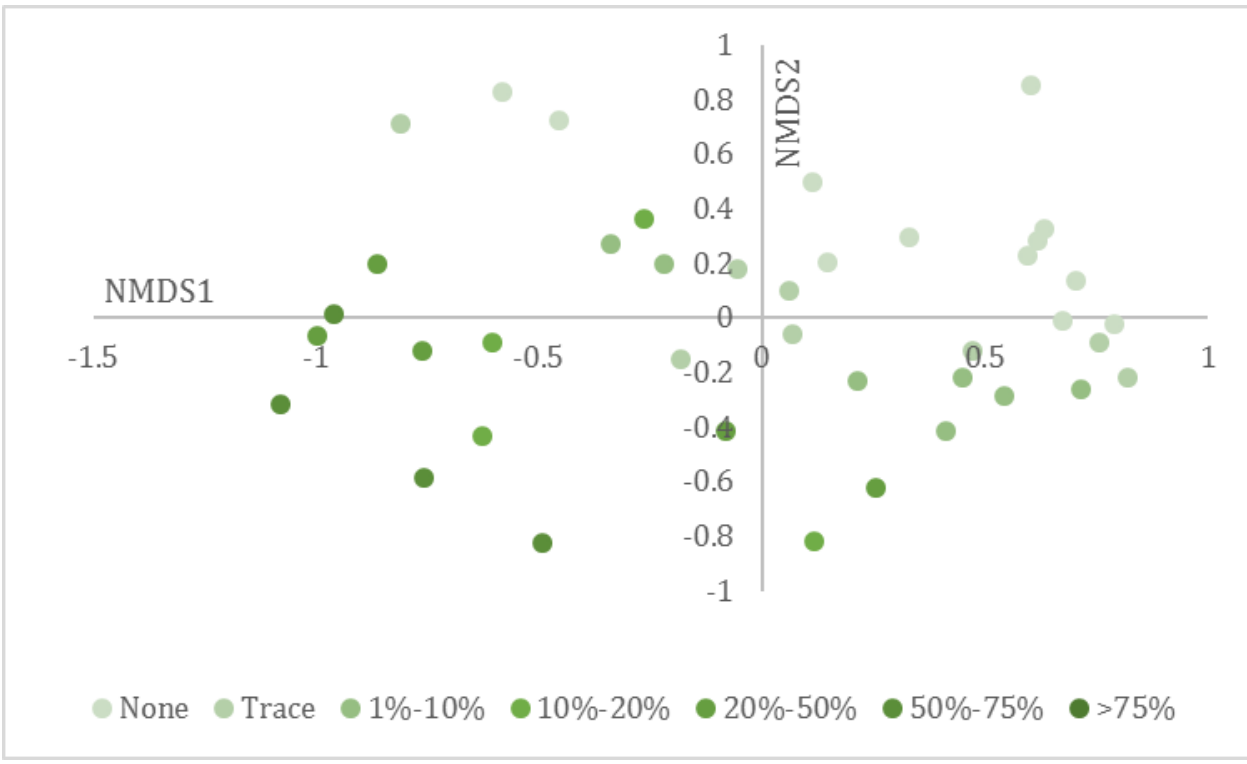

Figure 15: NMDS ordination of environmental variables at the landscape scale by site. Colors represent a gradient of ivy cover class.

Ordination by variables found several factors significant $(p<0.05)$ to the model, most prominently ivy, ivy spatial dependency, and interiority (Fig. 16).

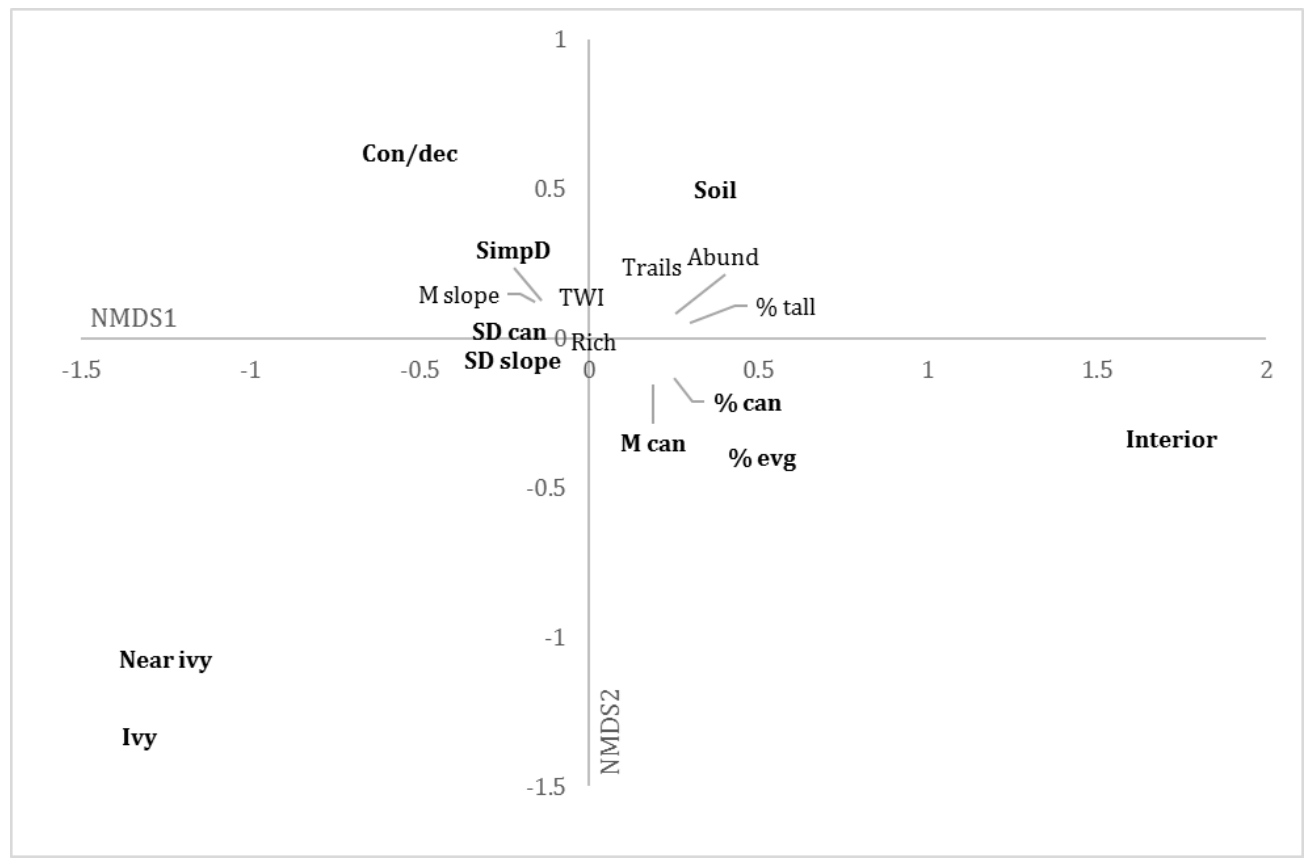

Figure 16: NMDS ordination of environmental variables at the landscape scale. Variables significant $(\mathrm{p}<0.05)$ to the model are in bold. 
Of the 11 significant variables, interiority, ivy, ivy spatial dependency, and mean canopy height were the most influential on the ordination model (Fig. 17).

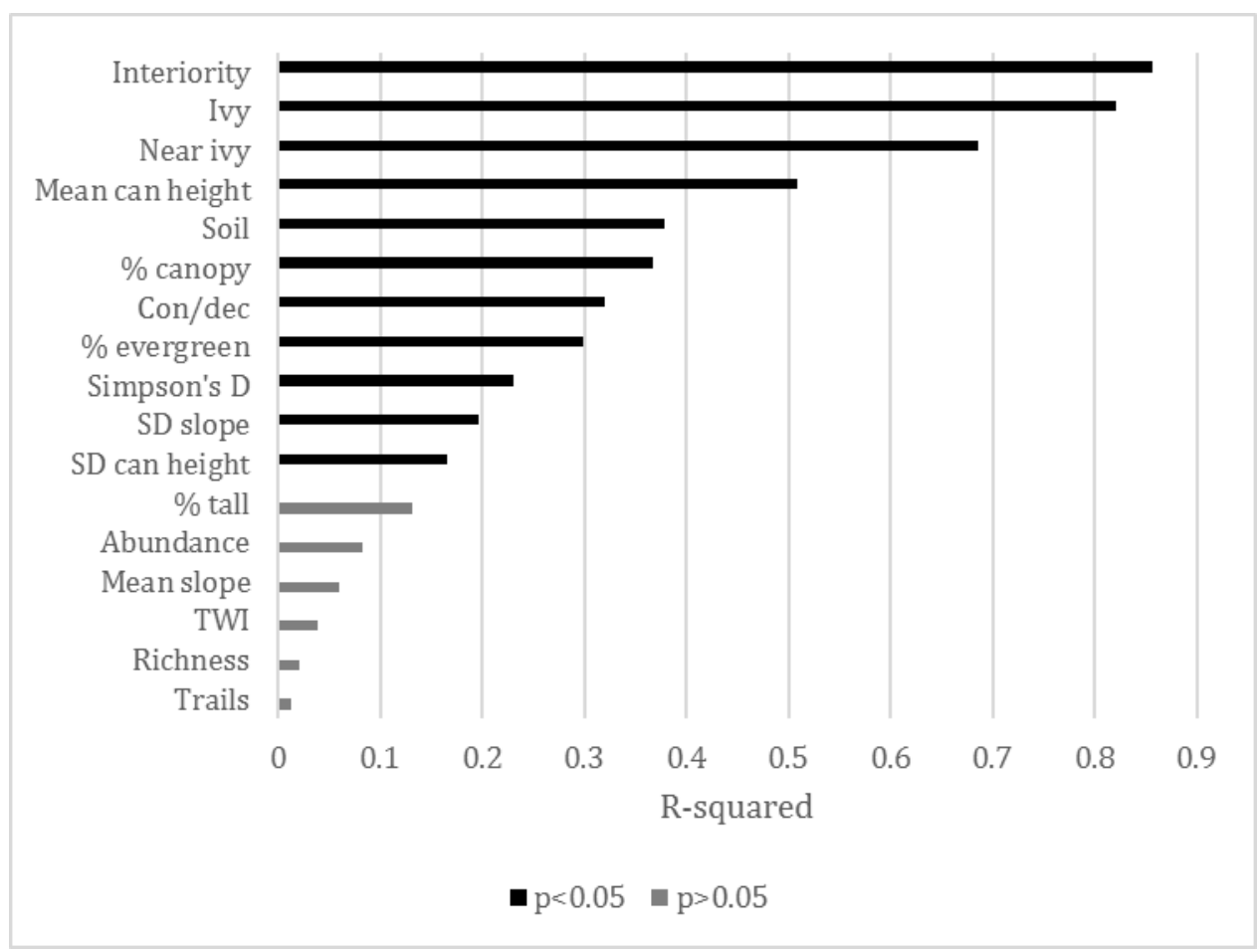

Figure 17: Importance of all variables in the landscape-scale NMDS ordination model of environmental predictors.

Random Forest regression of all predictors ( 9 tries per node, 1000 runs)

produced a model which explained $50.85 \%$ of the variance in ivy abundance (MSR $=$ 0.0392). Spatial dependency of ivy emerged as by far the strongest predictor in this model (Fig. 18, top). The best reduced regression model, with 3 predictors ( 2 tries per node, 1000 runs) explained $58.46 \%$ of variance (MSR $=0.0332$ ); ivy spatial dependency remained the strongest predictor, along with soil and slope variance (Fig. 18, bottom). 

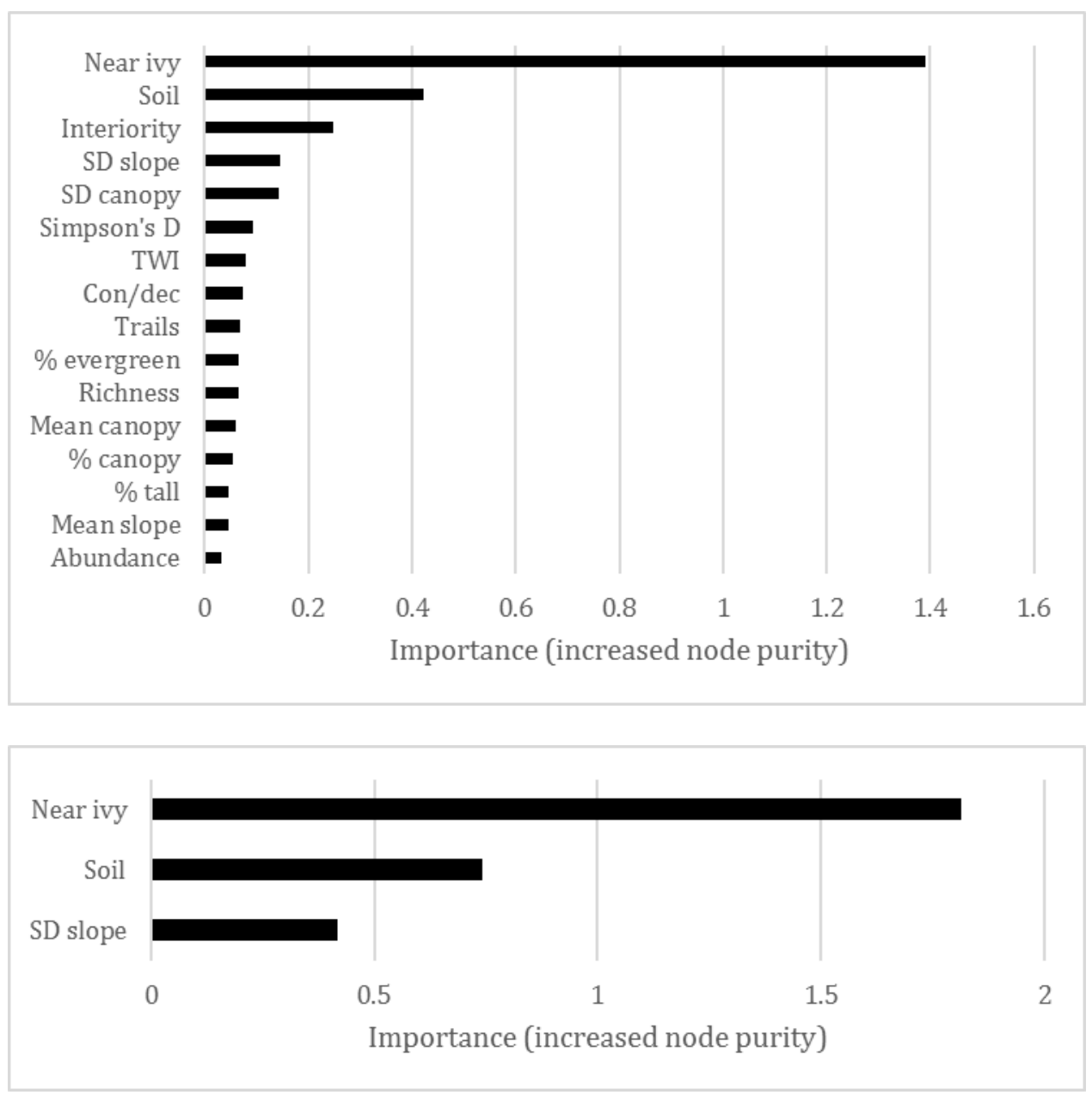

Figure 18: Relative importance (measured as increased node purity) of independent variables in the full (top) and reduced (bottom) Random Forest regression models of predictors of ivy abundance at the landscape scale. The full model explained $50.85 \%$ of the variance in ivy; the reduced model explained $58.46 \%$.

Intermediate Scale: Balch Treatment Area

At the intermediate scale, ivy is again highly positively correlated with the abundance of ivy in nearby areas, as well as with shrub abundance, and negatively correlated with evergreen shrubs, coniferous canopy, and distance from roads or trails (Table 6). 
Table 6: Spearman rank correlation values between ivy and environmental predictors at the intermediate scale. P-values are estimates due to tie ivy scores.

\begin{tabular}{|l|l|l|}
\hline Variable & Spearman rank R-value & Estimated p-value \\
\hline Shrub abundance & 0.783 & $<0.0001^{* * *}$ \\
\hline Shrub \% evergreen & -0.489 & $0.0002^{* * *}$ \\
\hline Spatial dependency of ivy & 0.362 & $0.007^{* *}$ \\
\hline Con/dec ratio & -0.274 & $0.043^{*}$ \\
\hline Trail proximity & -0.269 & $0.047^{*}$ \\
\hline Shrub Simpson's D & -0.250 & 0.065 \\
\hline CWD & -0.226 & 0.097 \\
\hline Shrub \% tall & 0.218 & 0.109 \\
\hline Shrub richness & -0.200 & 0.144 \\
\hline Mean canopy height & 0.169 & 0.219 \\
\hline SD slope & 0.163 & 0.233 \\
\hline SD canopy height & 0.137 & 0.320 \\
\hline Mean slope & -0.115 & 0.405 \\
\hline TWI & -0.048 & 0.727 \\
\hline
\end{tabular}

NMDS ordination (2 axes, Euclidian distance, 20 runs) produced a viable model with a non-metric $\mathrm{R}^{2}$ of 0.966 and a model stress of 0.1841 (Fig. 19). 


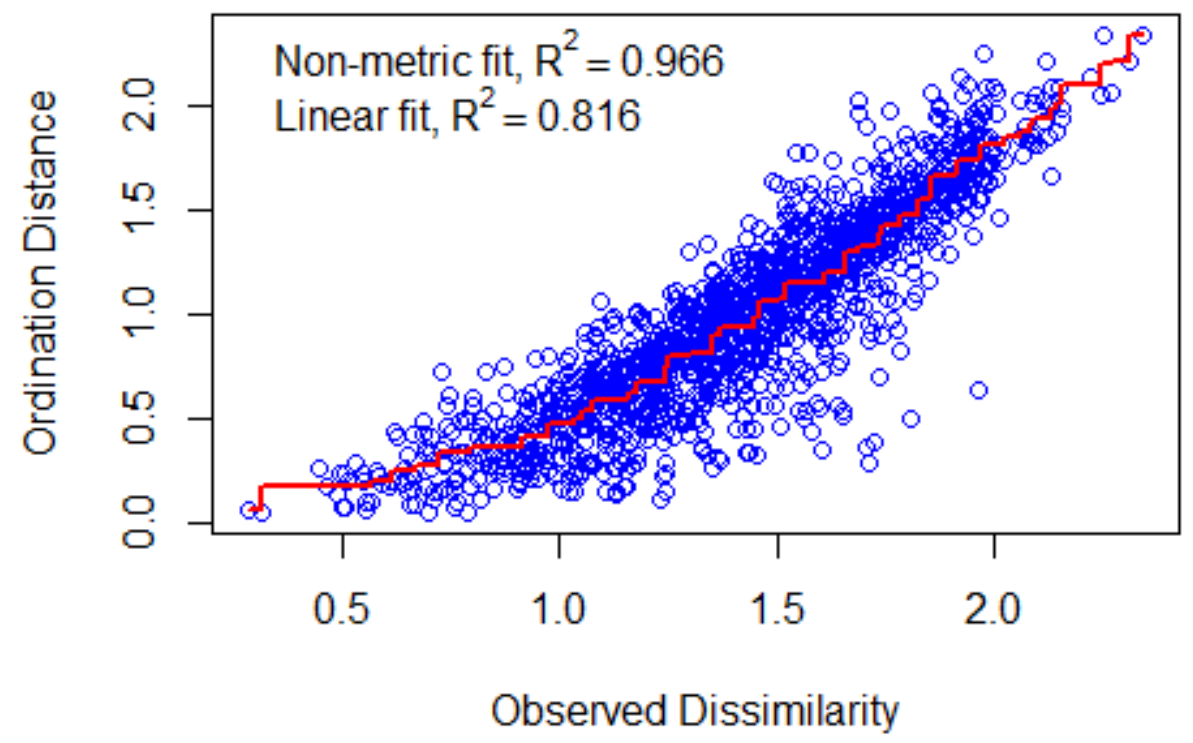

Figure 19: Stressplot of the intermediate-scale NMDS ordination of environmental variables ( 2 axes, 20 runs, model stress $=0.1841)$.

Ordination by sites showed a fairly pronounced gradient of ivy abundance along NMDS1 (Fig. 20).

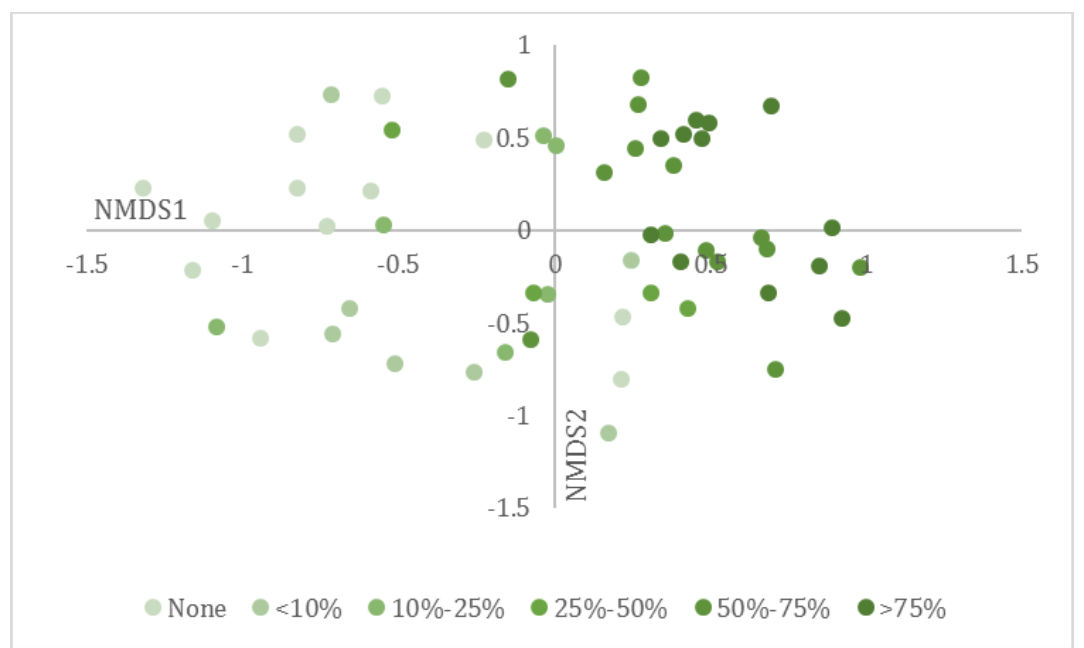

Figure 20: NMDS ordination of environmental variables at the intermediate scale by site. Colors represent ivy abundance. 
Ordination by variable found several significant ecological factors, confirming the influence of ivy and its spatial self-dependency, among others (Fig. 21).

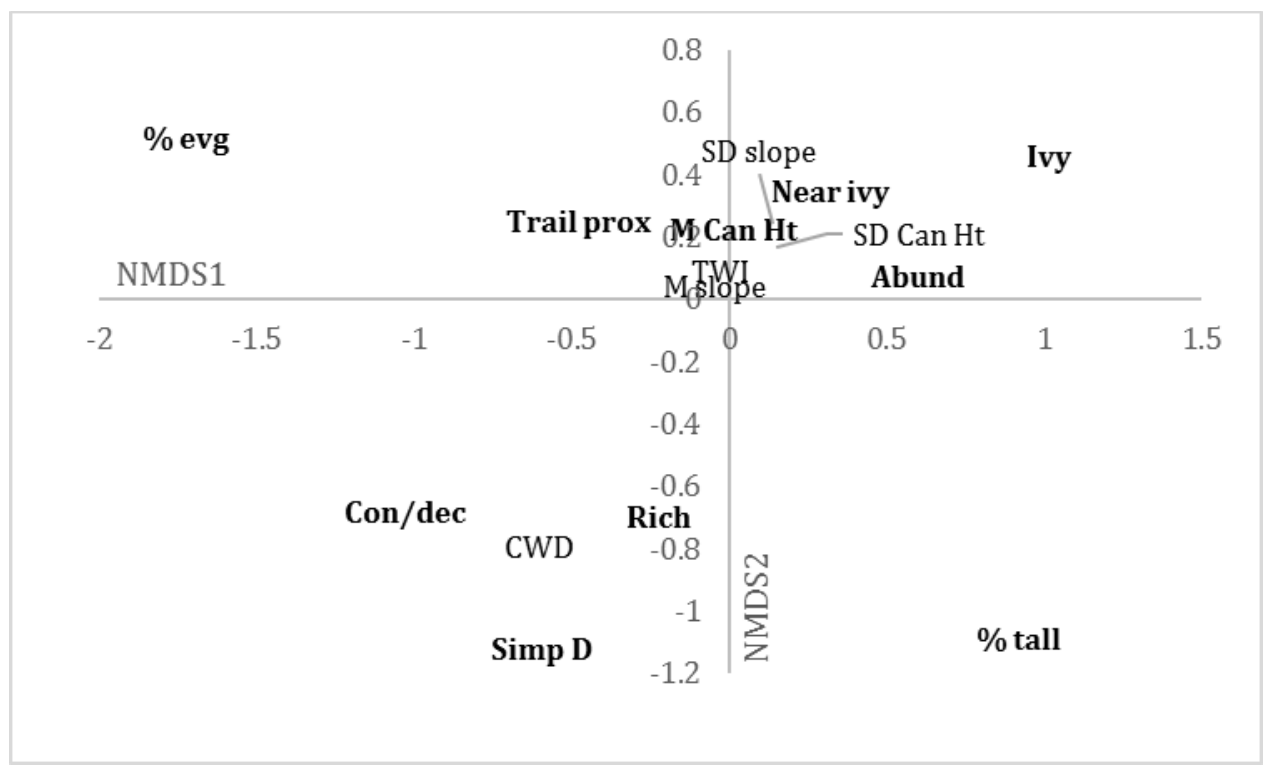

Figure 21: NMDS ordination of environmental variables at the intermediate scale. Variables significant $(\mathrm{p}<0.05)$ to the model are in bold.

11 variables were identified as significant to the model; the most influential were tall shrubs and ivy (Fig. 22). 


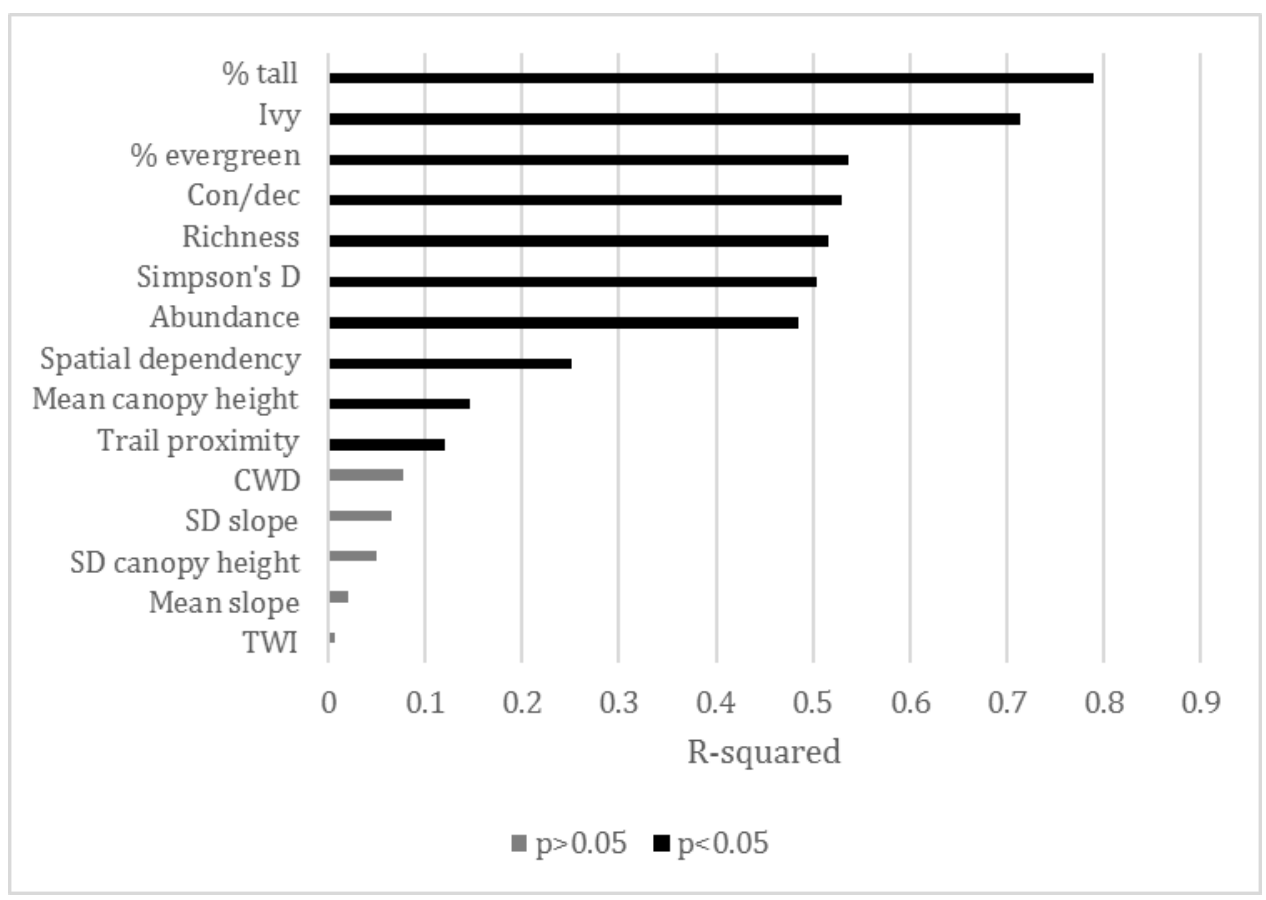

Figure 22: Importance of all variables in the intermediate-scale NMDS ordination model of environmental predictors.

Random Forest regression with all variables ( 9 tries per node, 1000 runs) produced a model which explained $57.82 \%$ of the variance in ivy abundance (MSR = 0.0545). Shrub abundance was by far the strongest predictor (Fig. 23, top). The best reduced model ( 2 tries per node, 1000 runs) explained $62.15 \%$ of the variance in ivy abundance $(\mathrm{MSR}=0.0501)$ with 4 variables; shrub abundance was again the most important predictor (Fig. 23, bottom). 

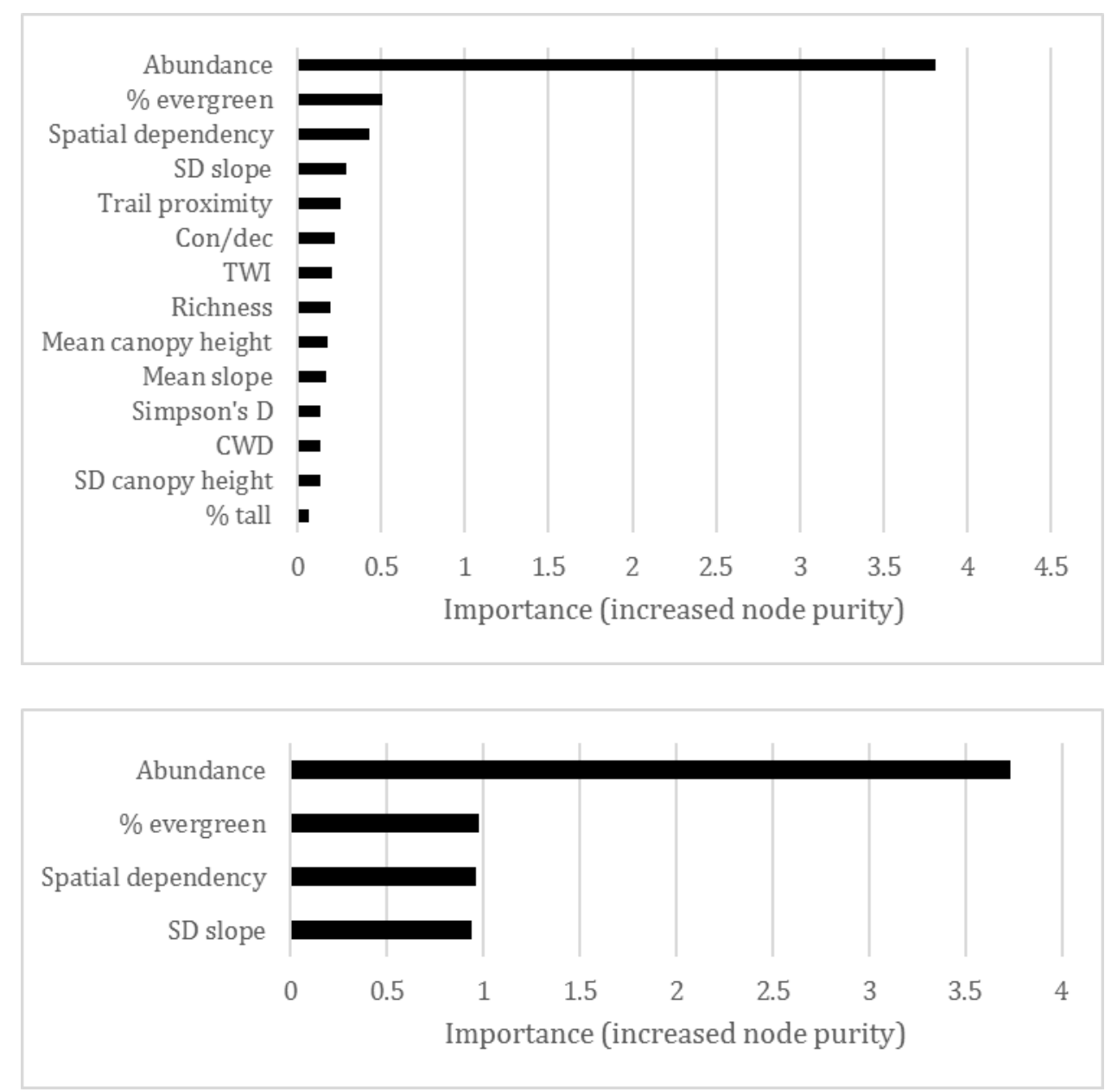

Figure 23: Relative importance of variables in the full (top) and best reduced (bottom) Random Forest regression models for the intermediate-scale predictors of ivy abundance. The full model explained $57.82 \%$ of the variance in ivy; the reduced model explained $62.15 \%$.

Site Scale: Balch Creek Research Plots

At the site scale, ivy appears to be positively correlated with median canopy height and slope, and negatively correlated with coarse woody debris abundance (Table 7). 
Table 7: Spearman rank correlation values between ivy and environmental predictors at the site scale. P-values are estimates due to tie ivy scores.

\begin{tabular}{|l|l|l|}
\hline Predictor variable & Spearman-rank R-value & Estimated p-value \\
\hline CWD & -0.635 & $0.0046^{* *}$ \\
\hline Slope & 0.549 & $0.018^{*}$ \\
\hline Median canopy height & -0.502 & $0.034^{*}$ \\
\hline Stem count & -0.449 & 0.061 \\
\hline Soil moisture & 0.414 & 0.088 \\
\hline Soil pH & 0.357 & 0.146 \\
\hline \% conifer by basal area & 0.220 & 0.381 \\
\hline Shrub \% evergreen & -0.219 & 0.383 \\
\hline Soil \% organic matter & 0.213 & 0.397 \\
\hline SD canopy height & 0.162 & 0.520 \\
\hline Shrub abundance & 0.133 & 0.600 \\
\hline Shrub richness & 0.130 & 0.608 \\
\hline \% conifer by stem count & -0.104 & 0.682 \\
\hline Snags & 0.085 & 0.737 \\
\hline Sum basal area & -0.064 & 0.800 \\
\hline Shrub \% tall & 0.011 & 0.964 \\
\hline
\end{tabular}

NMDS ordination ( 2 axes, Euclidian distance, 20 runs) produced an adequate model with a non-metric $\mathrm{R}^{2}$ of 0.976 and a model stress of 0.1556 (Fig. 24). 


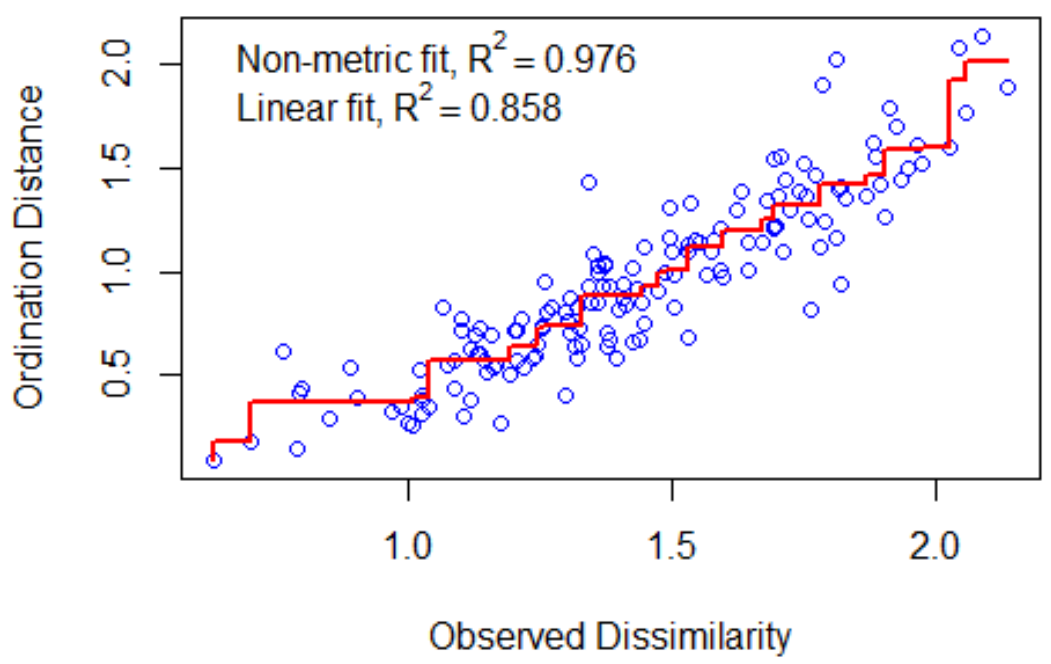

Figure 24: Stressplot of the site-scale NMDS ordination of environmental variables ( 2 axes, 20 runs, model stress $=0.1556)$.

Ordination by sites showed no unambiguous gradient of ivy, though there was a possible trend toward quadrant 1 (Fig. 25).

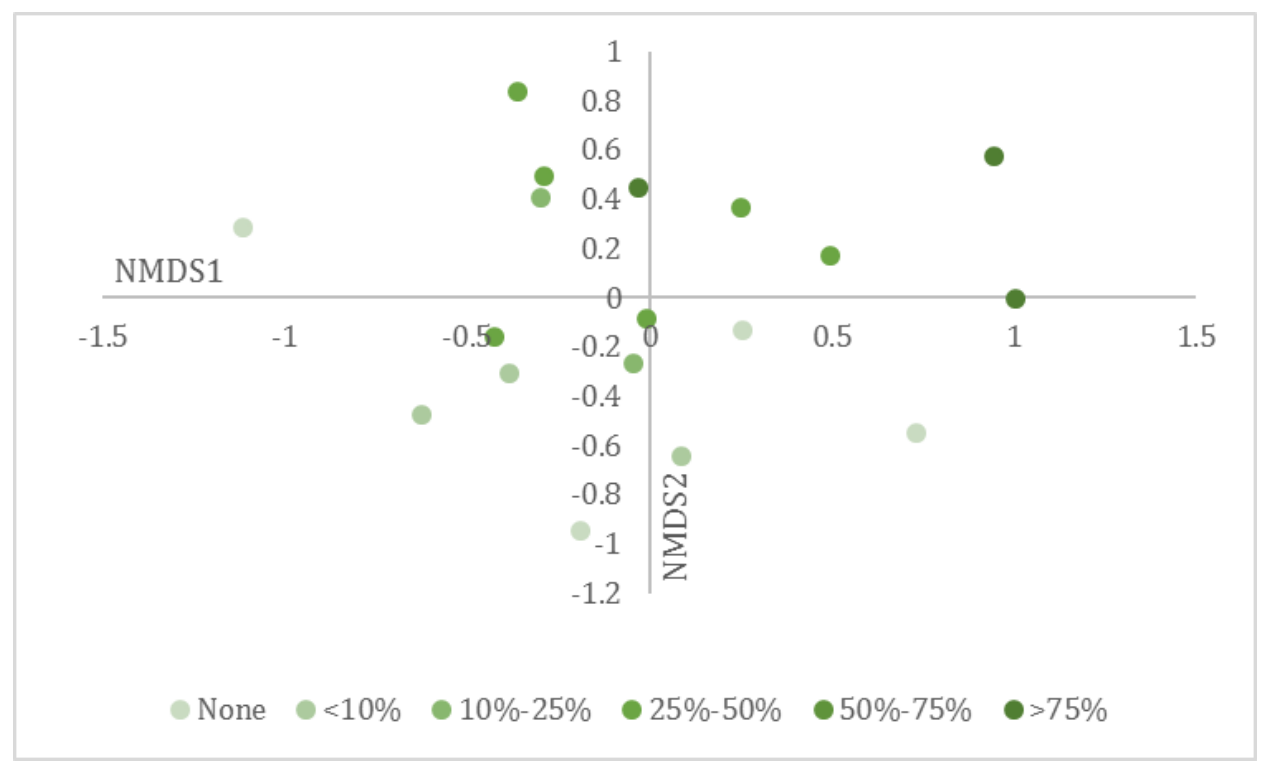

Figure 25: NMDS ordination of environmental variables at the site scale by site. Colors represent a gradient of ivy abundance. 
Ordination by variable revealed that ivy abundance and multiple shrub metrics appeared influential to the model (Fig. 26).

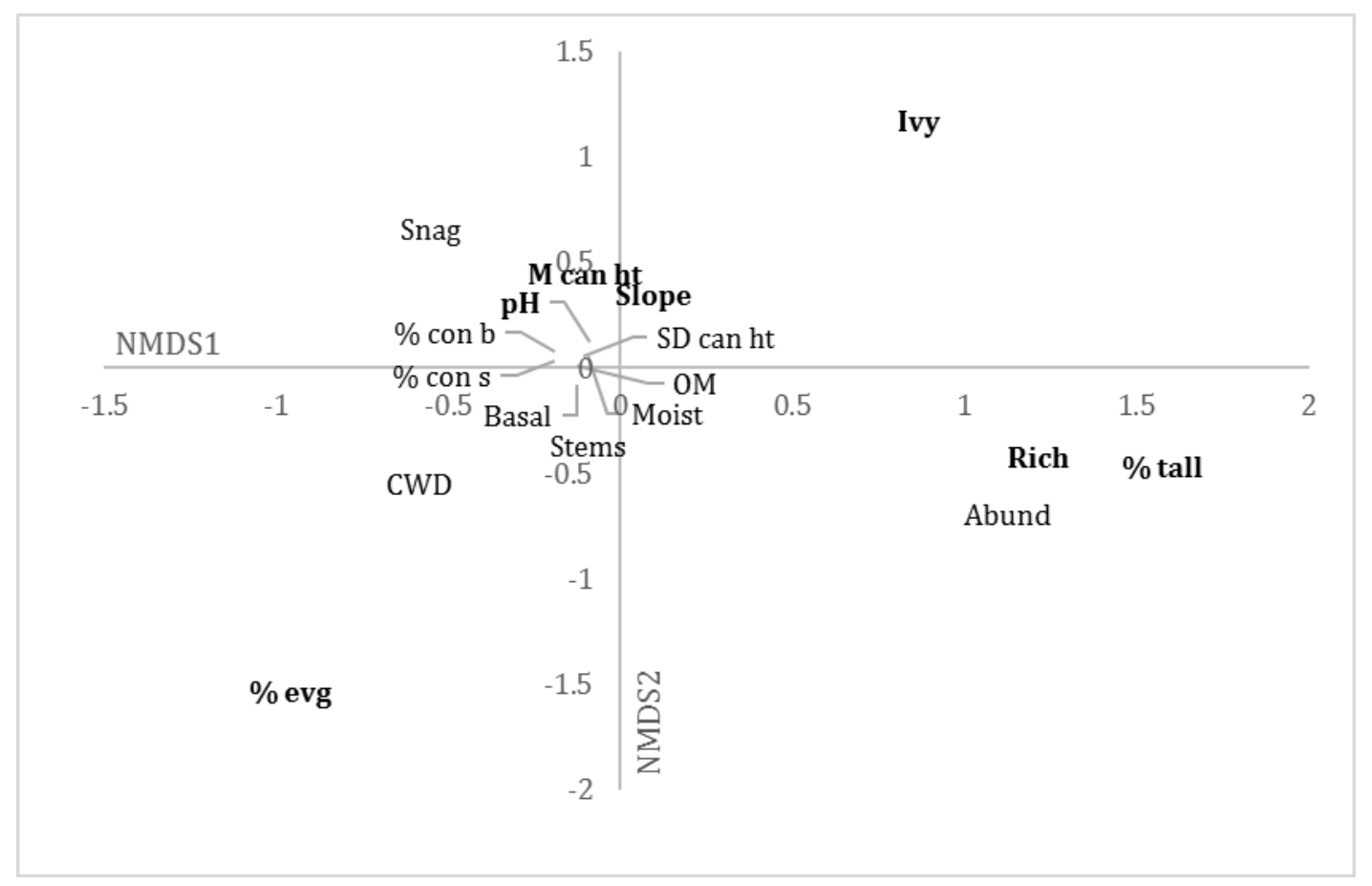

Figure 26: NMDS ordination of environmental variables at the site scale. Variables significant $(\mathrm{p}<0.05)$ to the model are in bold.

Shrub species richness and abundance appeared to be the two most important variables in the model, but ivy abundance was also significant (Fig. 27). 


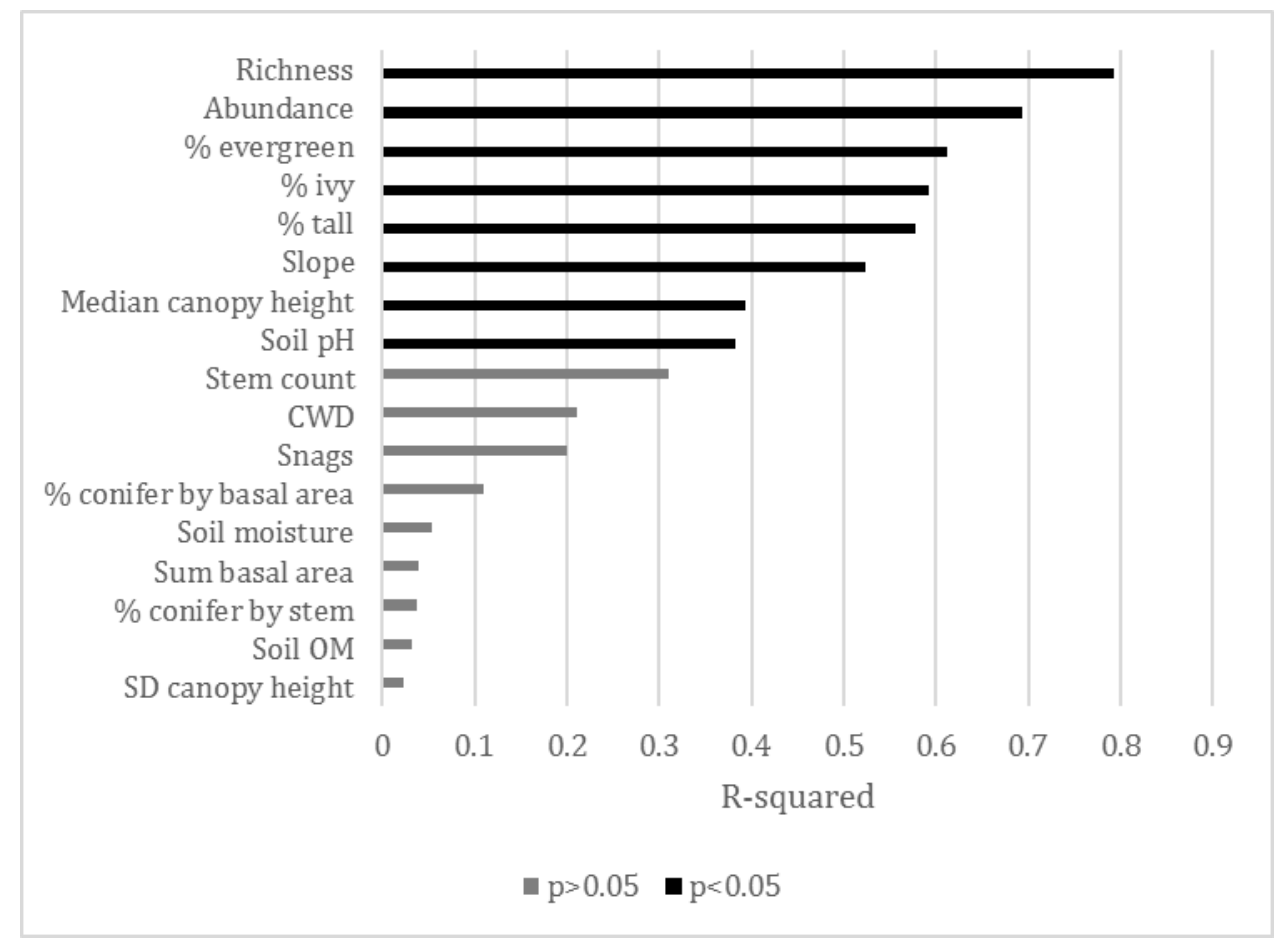

Figure 27: Importance of all variables in the site-scale NMDS ordination model of environmental predictors.

Random Forest regression with all predictors ( 2 tries per node, 300 runs)

produced a model which identified some apparently important predictors of ivy abundance but failed to explain any variance (MSR = 0.1302) (Fig. 28, top). A model with 4 variables ( 2 tries per node, 1000 runs) explained $3.02 \%$ of variance in ivy $(\mathrm{MSR}=0.1078)$, with CWD and slope appearing as the most important predictors (Fig. 28, bottom). 

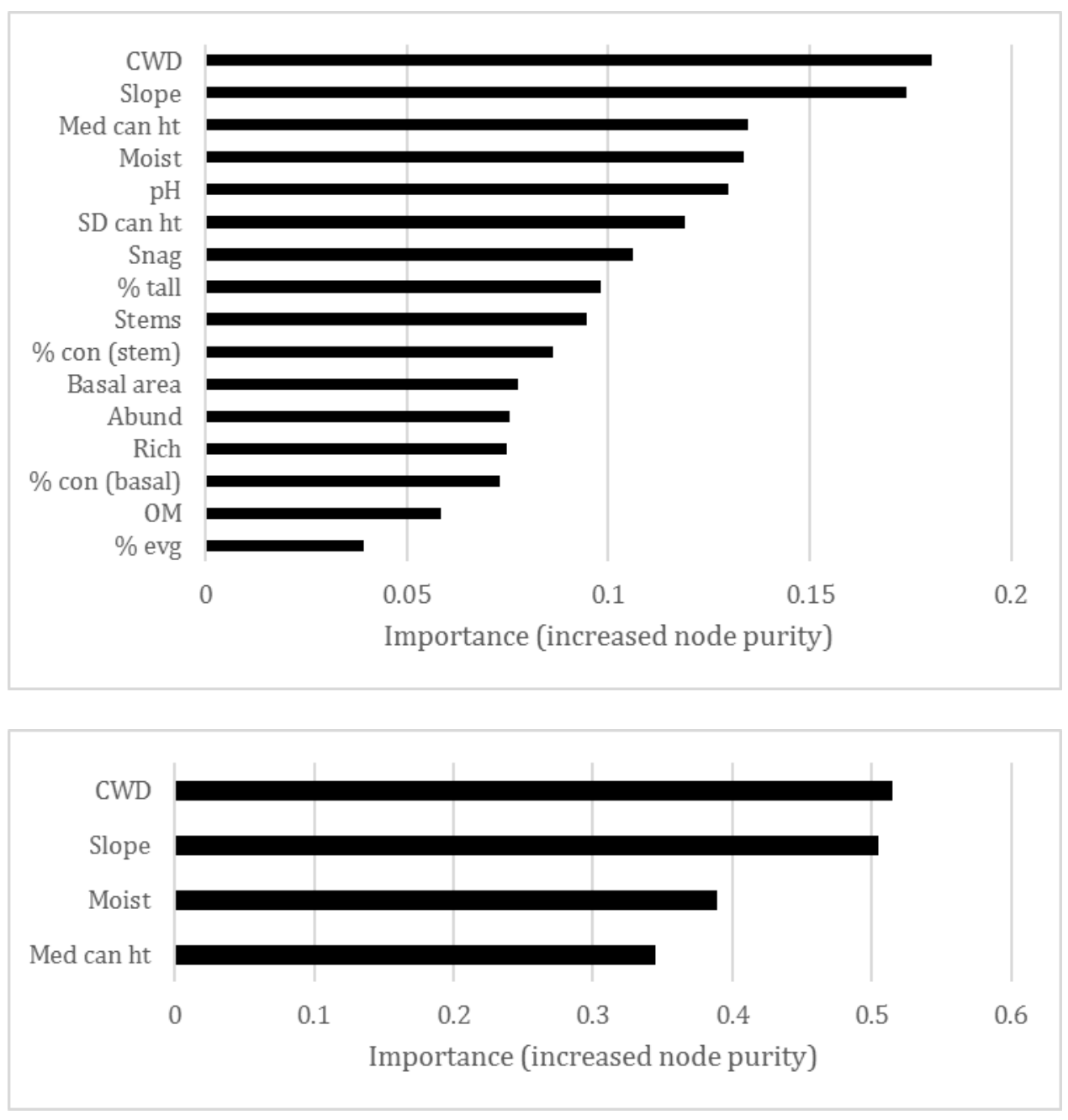

Figure 28: Relative importance of independent variables in the full (top) and reduced (bottom) Random Forest regression models of predictors of ivy abundance at the site scale. The full model explained none of the variance in ivy; the reduced model explained $3.02 \%$.

Section 3: Ivy-Shrub Community Interactions

\section{Question}

Do shrub communities differ at different levels of ivy invasion? 
Ivy may have positive or negative interactions with many woody plant species in the landscapes it invades, and these relationships can define a shrub community's vulnerability to and resilience under ivy invasion. I used correlation tests, ordination, and multiple regression to identify significant trends in shrub abundance by species using vegetation data from the three monitoring datasets across spatial scales.

Data

I tabulated all shrub and small tree species (defined as woody plants not typically canopy-forming) present in the sample data (Table 8) by sample unit (polygon at the landscape scale, UMP point at the intermediate scale, and transect segment at the site scale) along with ivy abundance. Any shrub species detected in $<10 \%$ of each subsample I omitted; as common native shrubs were not recorded at "trace" cover class, I recorded these values as "none" for ivy and non-native shrubs. I converted these cover classes to a 0-6 integer scale for statistical analysis. 
Table 8: Shrub species included in the community analyses at the three spatial scales. Shrubs detected in $<10 \%$ of any sample (gray cells) were not included in the respective analysis.

\begin{tabular}{|l|l|l|l|l|l|l|}
\hline Scientific name & Code & Evg & Tall & $\begin{array}{l}\text { Land } \\
(\mathbf{n = 4 0 )}\end{array}$ & $\begin{array}{l}\text { Interm } \\
(\mathbf{n = 5 9 )}\end{array}$ & $\begin{array}{l}\text { Site } \\
(\mathbf{n = 3 6 )}\end{array}$ \\
\hline Acer circinatum & ACCI & $\mathrm{N}$ & $\mathrm{Y}$ & 22 & 18 & 11 \\
\hline Corylus avellana & COAV & $\mathrm{N}$ & $\mathrm{Y}$ & 6 & 0 & 0 \\
\hline Corylus cornuta & COCO & $\mathrm{N}$ & $\mathrm{Y}$ & 10 & 6 & 4 \\
\hline Gaultheria shallon & GASH & $\mathrm{Y}$ & $\mathrm{N}$ & 8 & 3 & 4 \\
\hline Hedera spp. & Ivy & $\mathrm{Y}$ & $\mathrm{N}$ & 20 & 46 & 27 \\
\hline Holodiscus discolor & $\mathrm{HODI}$ & $\mathrm{N}$ & $\mathrm{Y}$ & 6 & 0 & 0 \\
\hline Ilex aquifolium & ILAQ & $\mathrm{Y}$ & $\mathrm{Y}$ & 19 & 3 & 7 \\
\hline Mahonia nervosa & MANE & $\mathrm{Y}$ & $\mathrm{N}$ & 26 & 19 & 22 \\
\hline Oemleria cerasiformis & OECE & $\mathrm{N}$ & $\mathrm{Y}$ & 44 & 6 & 2 \\
\hline Rosa gymnocarpa & ROGY & $\mathrm{N}$ & $\mathrm{N}$ & 5 & 0 & 4 \\
\hline Rubus parviflorus & RUPA & $\mathrm{N}$ & $\mathrm{N}$ & 10 & 3 & 4 \\
\hline Rubus spectabilis & RUSP & $\mathrm{N}$ & $\mathrm{N}$ & 14 & 1 & 10 \\
\hline Sambucus racemosa & SARA & $\mathrm{N}$ & $\mathrm{Y}$ & 8 & 6 & 4 \\
\hline Symphoricarpos albus & SYAL & $\mathrm{N}$ & $\mathrm{N}$ & 4 & 7 & 2 \\
\hline Vaccinium parflorum & VAPA & $\mathrm{N}$ & $\mathrm{N}$ & 22 & 7 & 11 \\
\hline
\end{tabular}

To ensure an adequate sample size at the site scale, I used all $3625 \mathrm{~m}$ segments in the middle 3 transects of each macroplot. Although the segments meet end-to-end, I tested them for spatial autocorrelation using cover values of the widespread shrub Mahonia nervosa (detected in 22 out of 36 segments). To do so, I calculated Moran's I for the segments in each macroplot in their original spatial configuration compared to a shuffled configuration designed to separate all proximate segments. Since the original configurations showed no significant $(p<0.05)$ spatial autocorrelation, and the shuffled configurations were not less spatially autocorrelated than the originals, I was able to treat the segments as spatially independent in subsequent analyses. 
Analysis

At all three analytical scales, I used NMDS ordination (R, vegan package, metaMDS function; parameters: 2 axes, 20 starts, Bray-Curtis similarity) to determine differences among "sites" (sample units) and "species" (shrubs) in relation to ivy, and plotted the sites ordination with ivy values to display any possible trends along an abundance gradient. I then used the envfit function to determine which species were most influential on overall community composition, and Random Forest regression with stepwise model reduction, coupled with Spearman rank correlation, to determine which shrubs are most predictive of ivy abundance.

At all scales, I omitted any sample units with no shrub or ivy detections, which would be incompatible with community similarity metrics and result in an ineffective ordination. This reduced my sample sizes to 39 at the landscape scale, 48 at the intermediate scale, and 35 at the site scale.

Results

Landscape Scale: Forest Park

Out of 14 shrub species with sufficient sample sizes for comparison, three $(I$. aquifolium, $M$. nervosa, and $R$. spectabilis) are significantly correlated (Spearman rank method) to ivy at the landscape scale (Table 9). 
Table 9: Spearman rank correlations between ivy and shrub species included in analysis at the landscape scale.

\begin{tabular}{|l|l|l|}
\hline Shrub species & Spearman-rank R-value & Estimated p-value \\
\hline ILAQ & 0.504 & $0.0009^{* * *}$ \\
\hline MANE & -0.440 & $0.0045^{* *}$ \\
\hline RUSP & -0.325 & $0.041^{*}$ \\
\hline COCO & 0.295 & 0.065 \\
\hline COAV & 0.290 & 0.069 \\
\hline SYAL & 0.227 & 0.159 \\
\hline VAPA & -0.203 & 0.209 \\
\hline HODI & -0.179 & 0.269 \\
\hline ACCI & -0.169 & 0.299 \\
\hline OECE & 0.099 & 0.543 \\
\hline GASH & 0.071 & 0.661 \\
\hline RUPA & 0.062 & 0.702 \\
\hline SARA & 0.049 & 0.762 \\
\hline ROGY & -0.028 & 0.863 \\
\hline
\end{tabular}

NMDS ordination (2 axes, Bray-Curtis similarity, 20 runs) produced an effective model with a non-metric $\mathrm{R}^{2}=0.976$ and model stress $=0.1561$ (Fig. 29).

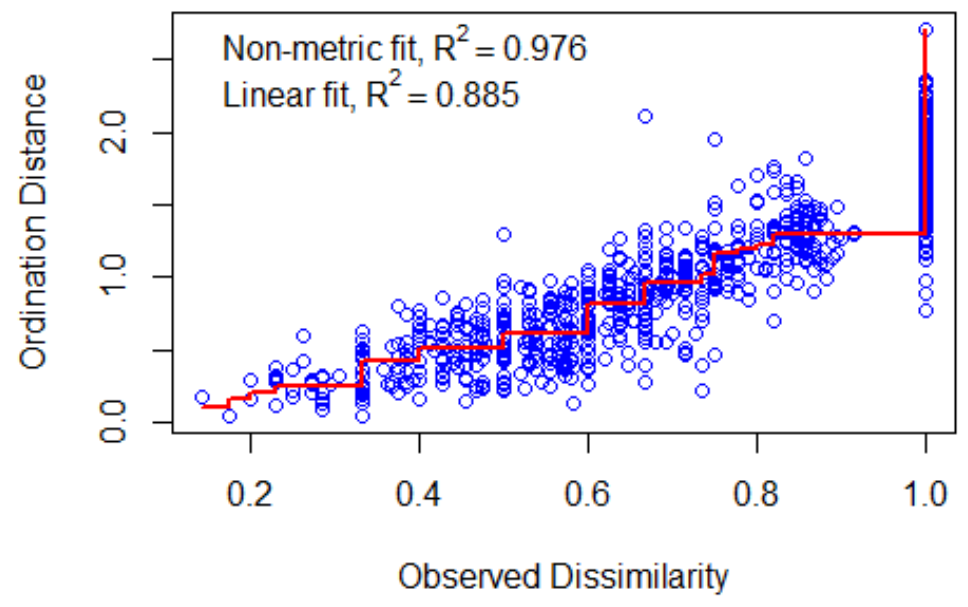

Figure 29: Stressplot of shrub community NMDS ordination at the landscape scale (2 axes, 20 runs, model stress $=0.1561$ ) 
Sites ordination revealed a possible weak ivy gradient toward Quadrant III

(Fig. 30).

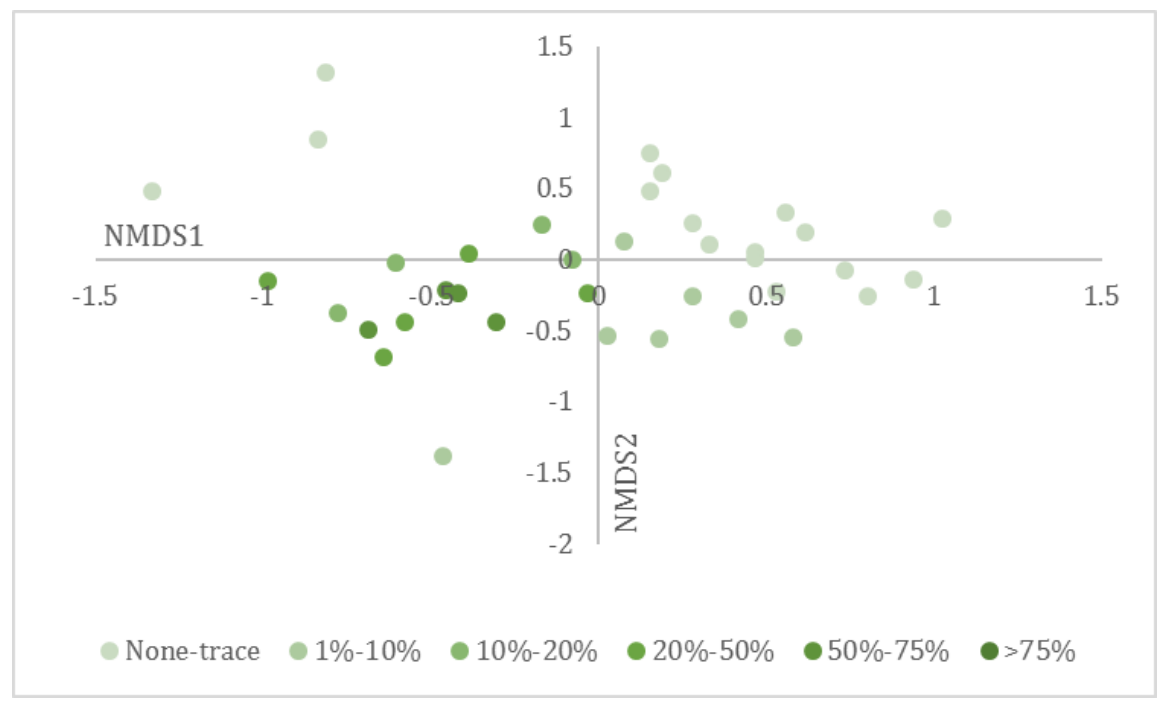

Figure 30: NMDS ordination of shrub community composition by site at the landscape scale. Colors represent ivy cover class.

Species ordination identified several shrubs with a significant $(\mathrm{p}<0.05)$ influence on community composition, including ivy (Fig. 31).

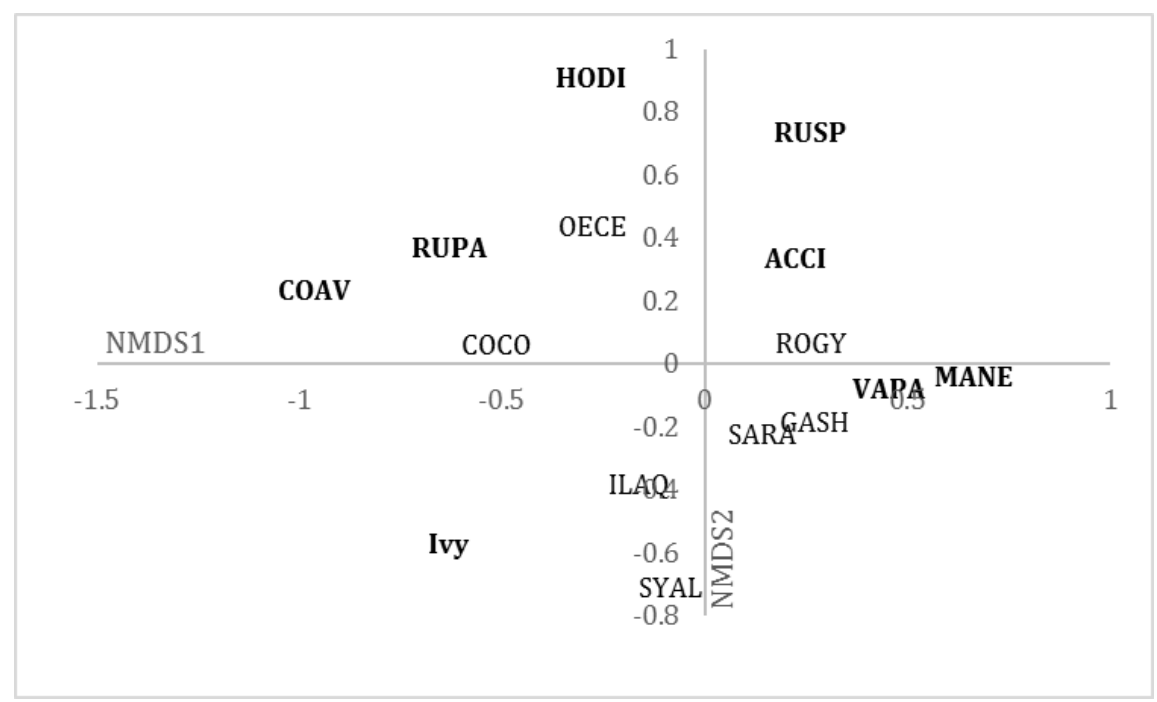

Figure 31: NMDS ordination of shrub community composition by species at the landscape scale. Species significant $(\mathrm{p}<0.05)$ to the model are in bold. 
Ivy, however, is only the second-most influential species in the model, after M. nervosa (Fig. 32).

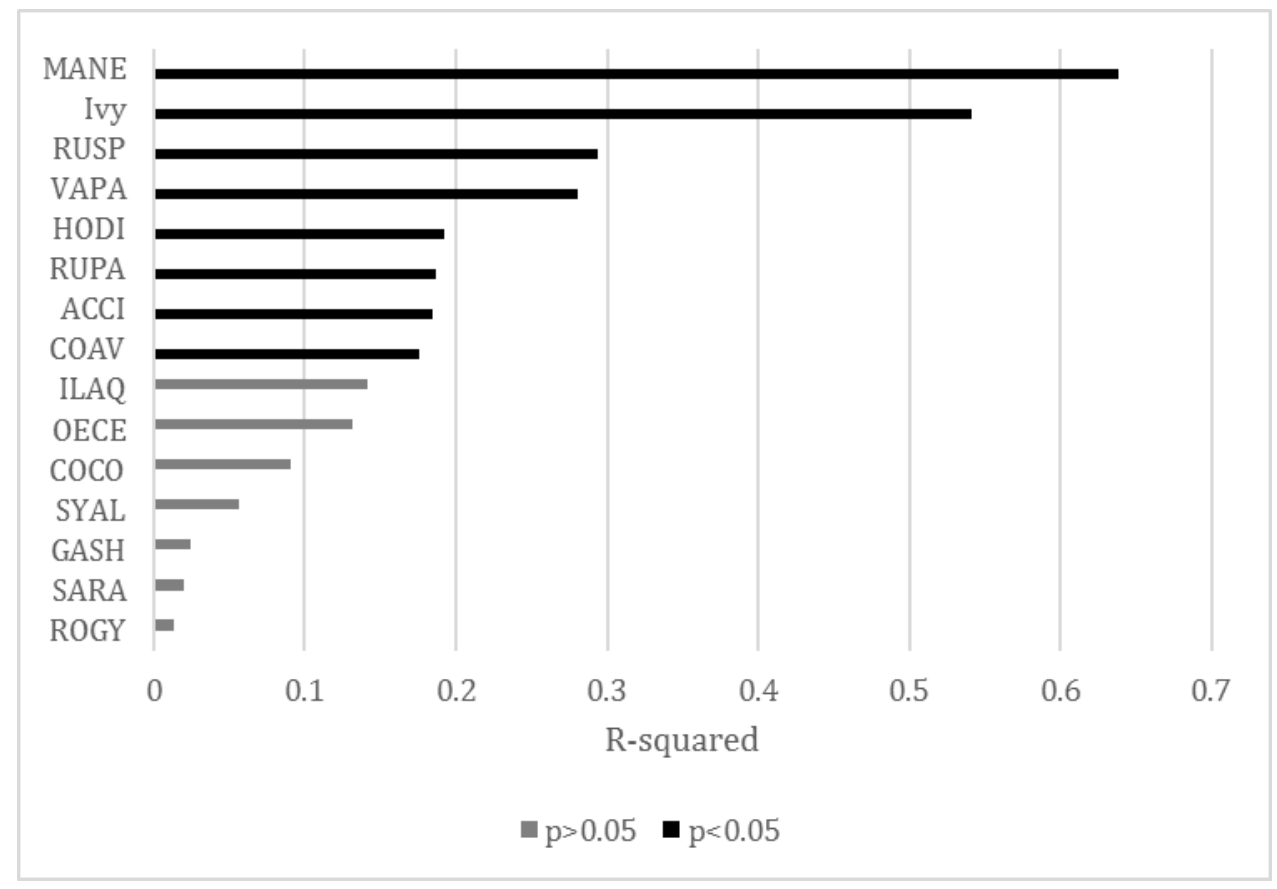

Figure 32: Importance of species to the shrub community NMDS ordination at the landscape scale

Random Forest regression suggests that, while most species in the model are affected (Fig. 33, top), M. nervosa, I. aquifolium, and C. avellana, and C. cornuta are the four species with the strongest relationships to ivy abundance at the landscape scale (Fig. 33, bottom). All shrub species collectively explain $28.64 \%$ of the variance in ivy abundance (mean of squared residuals (MSR) = 1.411); in the strongest reduced model, those four species explain $34.38 \%$ of the variance in ivy abundance $(\mathrm{MSR}=1.298)$ 

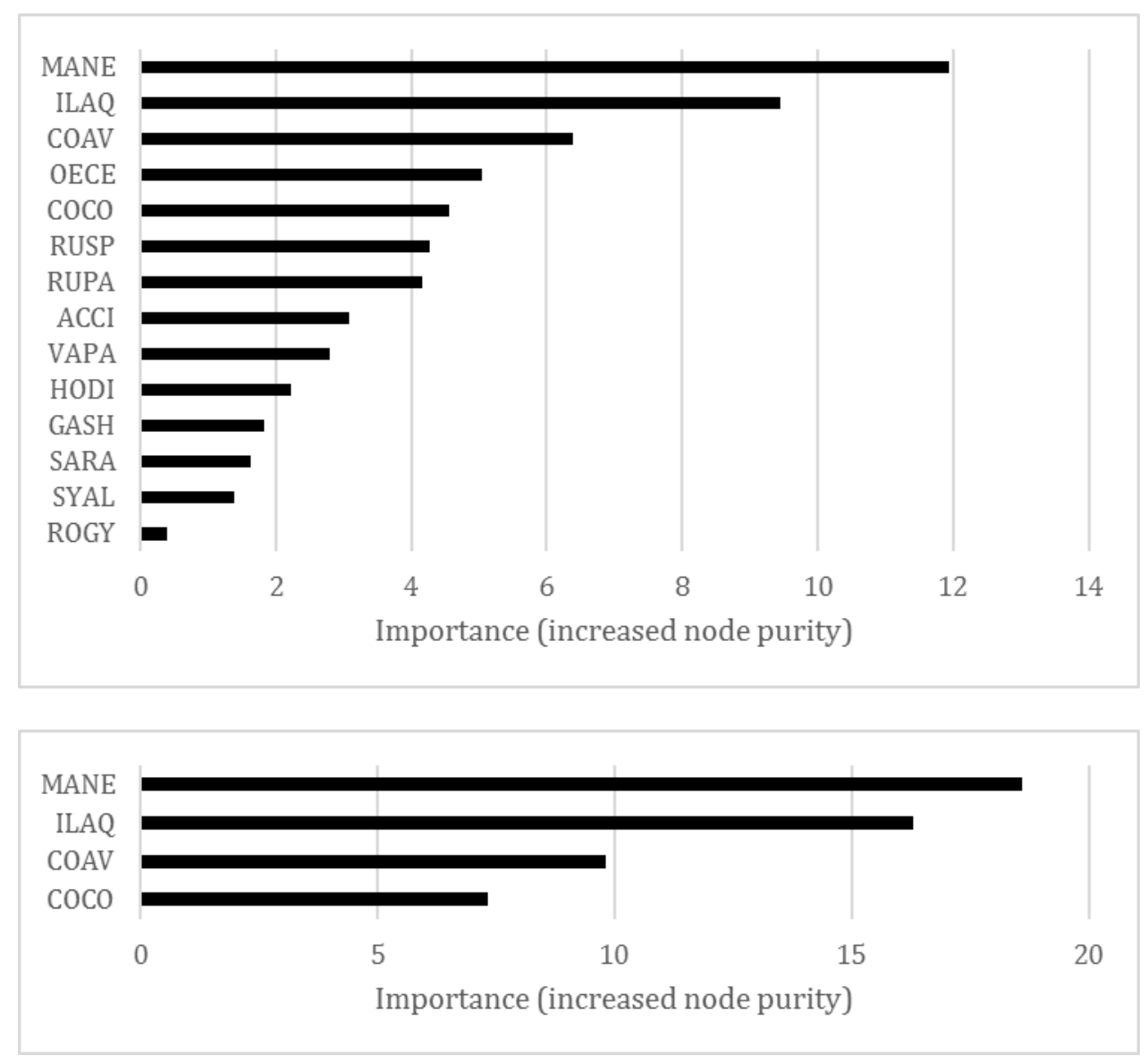

Figure 33: Relative importance of shrub species (measured as increased node purity) to the full (top) and strongest reduced (bottom) Random Forest regression models of ivy vs. shrub community composition at the landscape scale. The full model explained $28.64 \%$ of the variance in ivy; the reduced model explained $34.38 \%$.

Intermediate Scale: Balch Treatment Area

Three of the seven shrub species in the intermediate-scale shrub community analysis (A. circinatum, M. nervosa, and S. racemosa) appeared to have significant relationships to ivy as measured by Spearman rank correlation (Table 10). 
Table 10: Spearman rank correlations between ivy and shrub species included in analysis at the intermediate scale.

\begin{tabular}{|l|l|l|}
\hline Shrub species & Spearman-rank R-value & Estimated p-value \\
\hline SARA & 0.240 & $0.037^{*}$ \\
\hline ACCI & 0.232 & $0.044^{*}$ \\
\hline MANE & -0.232 & $0.044^{*}$ \\
\hline OECE & 0.138 & 0.236 \\
\hline COCO & 0.046 & 0.694 \\
\hline SYAL & -0.040 & 0.731 \\
\hline VAPA & -0.030 & 0.799 \\
\hline
\end{tabular}

NMDS ordination (2 axes, Bray-Curtis similarity, 20 runs) produced an effective model with a non-metric $\mathrm{R}^{2}=0.985$ and model stress $=0.1232$ (Fig. 34).

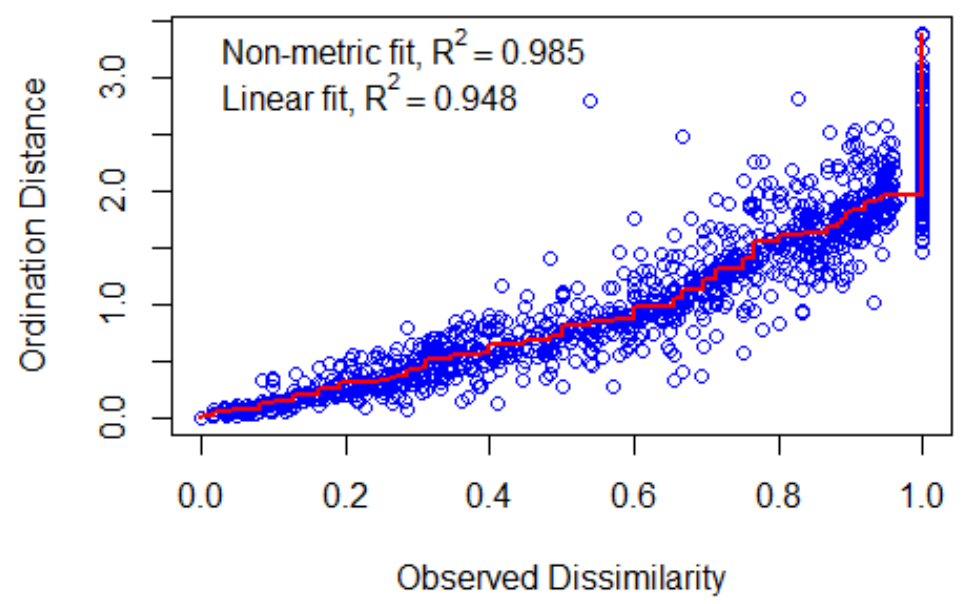

Figure 34: Stressplot of shrub community NMDS ordination at the intermediate scale ( 2 axes, 20 runs, model stress $=0.1232$ )

Sites ordination showed a pronounced gradient of ivy abundance along NMDS1 (Fig. 35). 


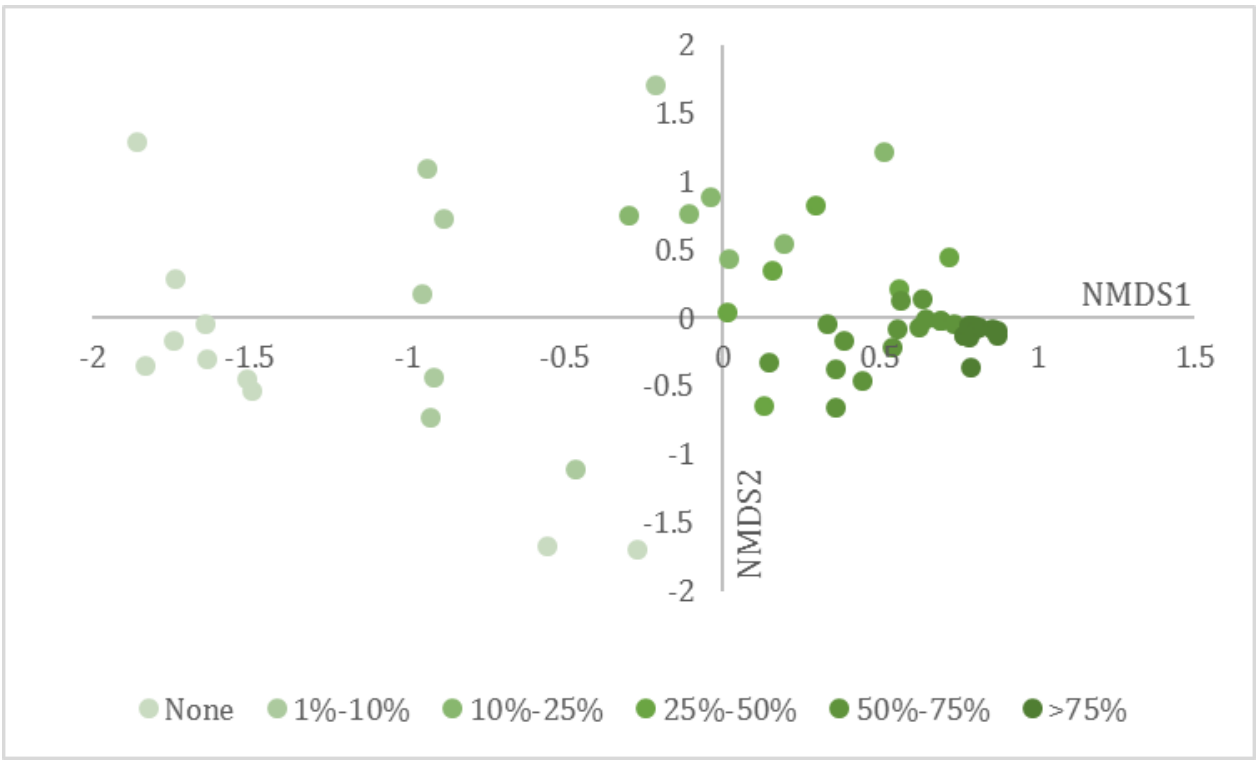

Figure 35: NMDS ordination of shrub community composition by site at the intermediate scale. Colors represent ivy abundance.

Species ordination found that ivy and three shrub species had a significant $(\mathrm{p}<0.05)$ influence on community composition, although $C$. cornuta was borderline at $\mathrm{p}=0.056$ (Fig. 36).

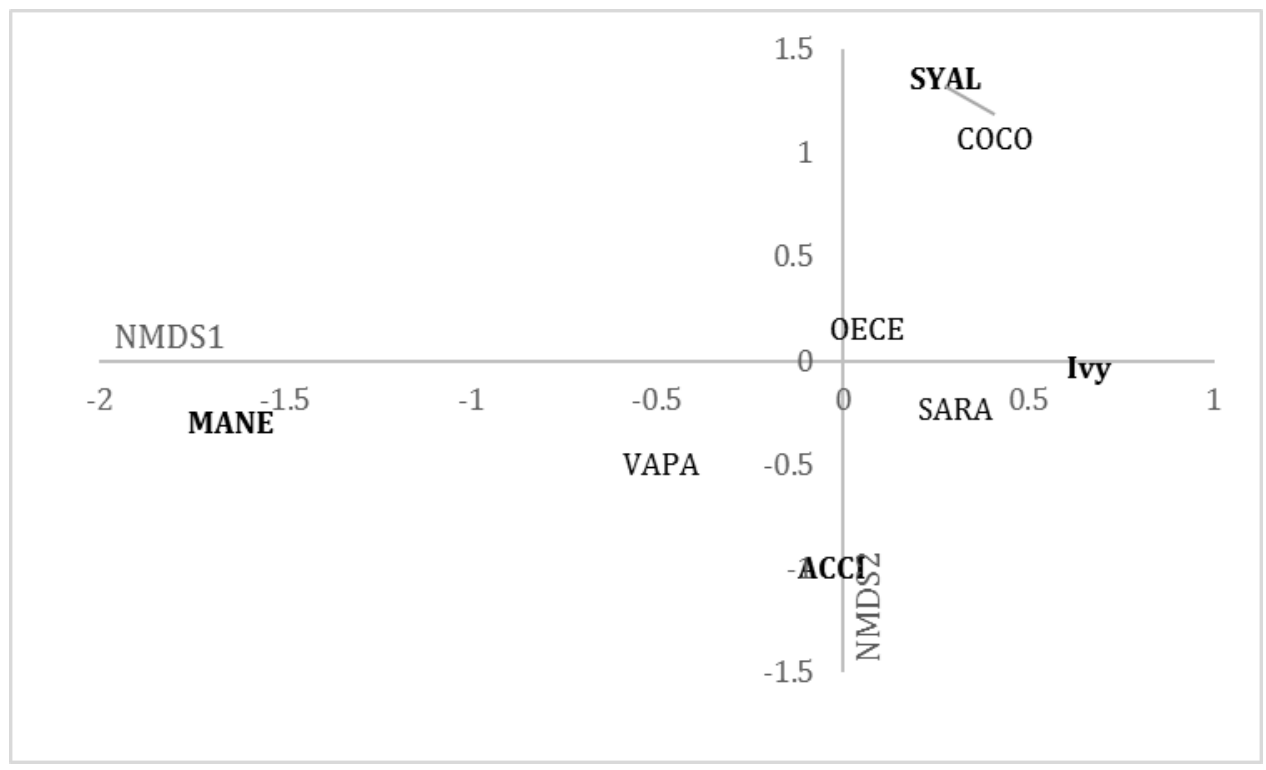

Figure 36: NMDS ordination of shrub community composition by species at the intermediate scale. Species significant $(\mathrm{p}<0.05)$ to the model are in bold. 
Ivy and M. nervosa are the two most important species to the community model at the intermediate scale (Fig. 37).

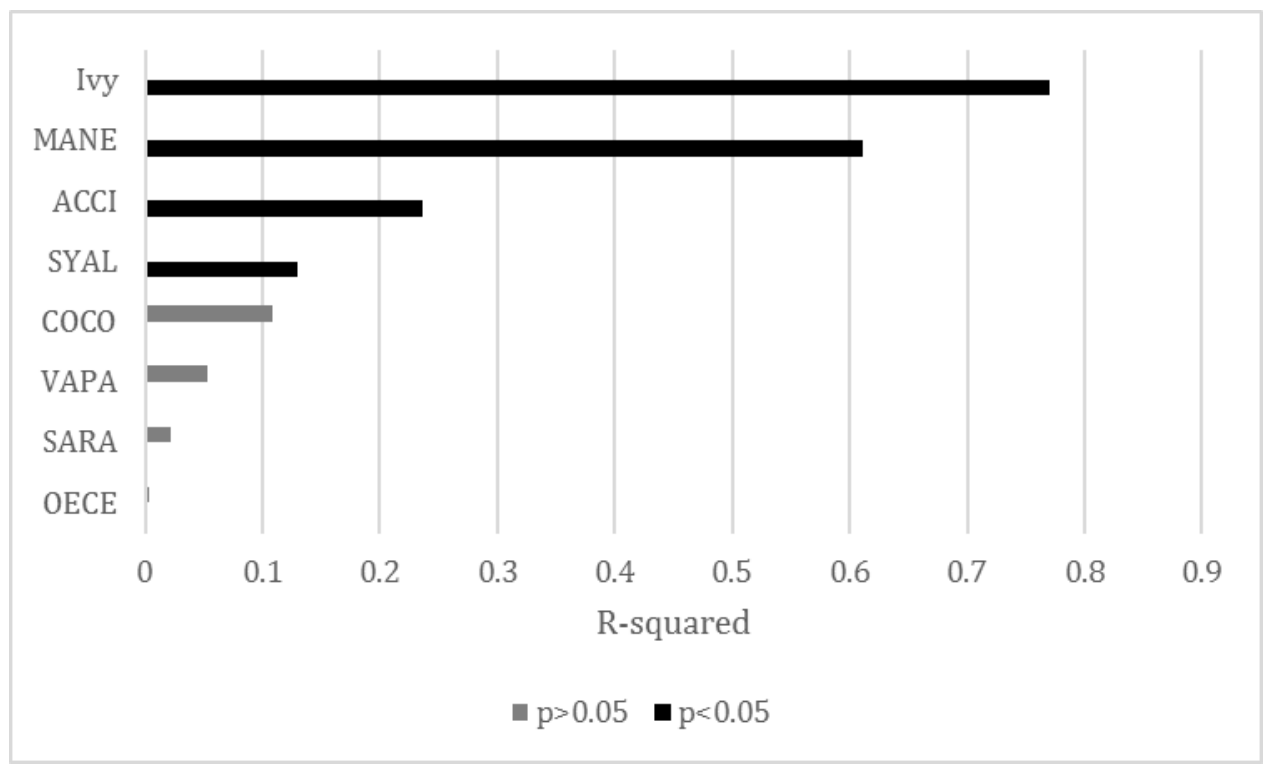

Figure 37: Importance of species to the shrub community NMDS ordination at the intermediate scale

RF regression with all shrub species (Fig. 38, top) explained 34.54\% of the variance in ivy abundance (MSR = 85.58); in the best reduced model (Fig. 38, bottom), the 3 most important species, M. nervosa, A. circinatum, and S. albus, together explained $37.80 \%$ of that variance $(\mathrm{MSR}=81.32$ ). 

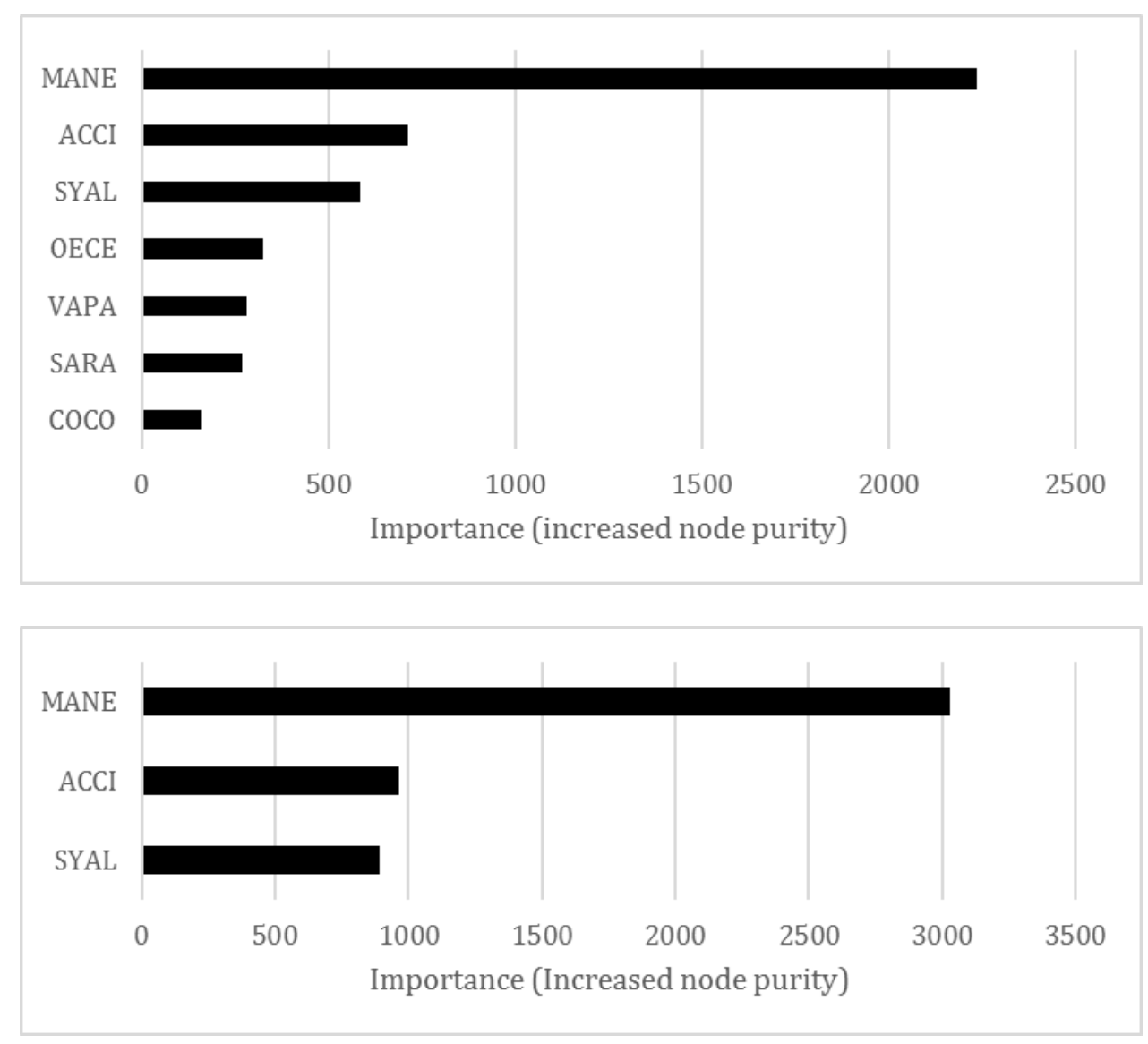

Figure 38: Relative importance of shrub species to the full (top) and strongest reduced (bottom) Random Forest regression models of ivy vs. shrub community composition at the intermediate scale. The full model explained $34.54 \%$ of the variance in ivy; the reduced model explained $37.80 \%$.

Site Scale: Balch Creek Research Plots

None of the 10 shrub species included in the site-scale analysis was significantly $(\mathrm{p}<0.05)$ correlated with ivy, but $S$. racemosa was borderline (Table 11). 
Table 11: Spearman rank correlations between ivy and shrub species included in analysis at the site scale.

\begin{tabular}{|l|l|l|}
\hline Shrub species & Spearman-rank R-value & Estimated p-value \\
\hline SARA & 0.323 & 0.055 \\
\hline GASH & -0.232 & 0.174 \\
\hline RUPA & 0.215 & 0.208 \\
\hline ACCI & -0.128 & 0.456 \\
\hline ROGY & 0.109 & 0.527 \\
\hline MANE & -0.101 & 0.559 \\
\hline VAPA & -0.085 & 0.623 \\
\hline ILAQ & 0.064 & 0.710 \\
\hline RUSP & 0.048 & 0.723 \\
\hline COCO & 0.011 & 0.951 \\
\hline
\end{tabular}

NMDS ordination (2 axes, Bray-Curtis similarity, 20 runs) produced an

effective model with a non-metric $\mathrm{R}^{2}=0.981$ and model stress $=0.1386$ (Fig. 39).

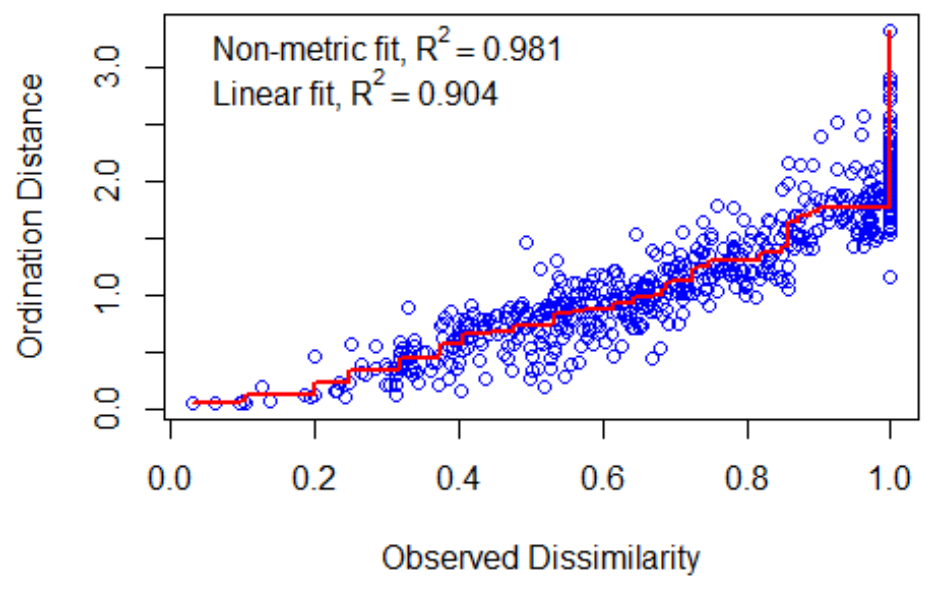

Figure 39: Stressplot of shrub community NMDS ordination at the site scale (2 axes, 20 runs, model stress $=0.1386$ )

Sites ordination showed a possible gradient of ivy abundance along NMDS1, but nothing conclusive (Fig. 40). Audubon plot, without substantial ivy invasion but 
with other known ecological differences as well, appeared to be largely distinct from Coyote and Balch plots (Fig. 41).

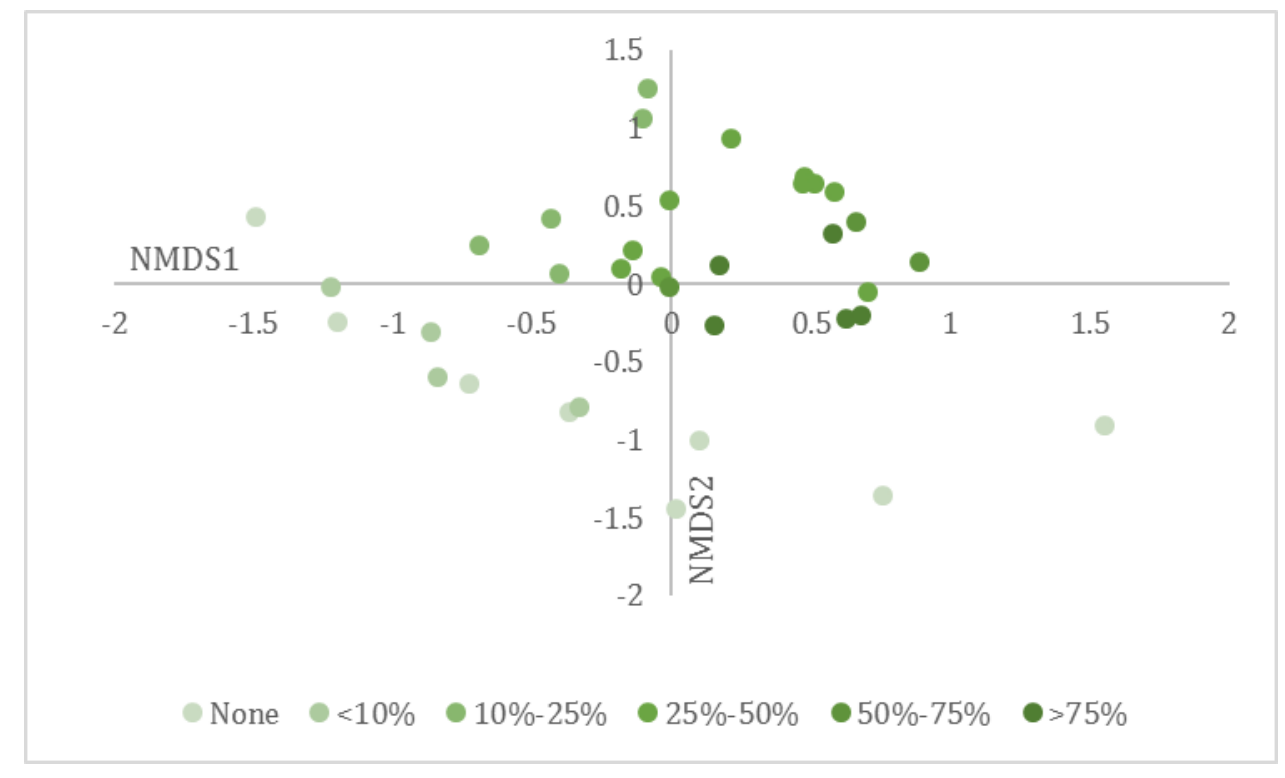

Figure 40: NMDS ordination of shrub community composition by site at the site scale. Colors represent ivy abundance.

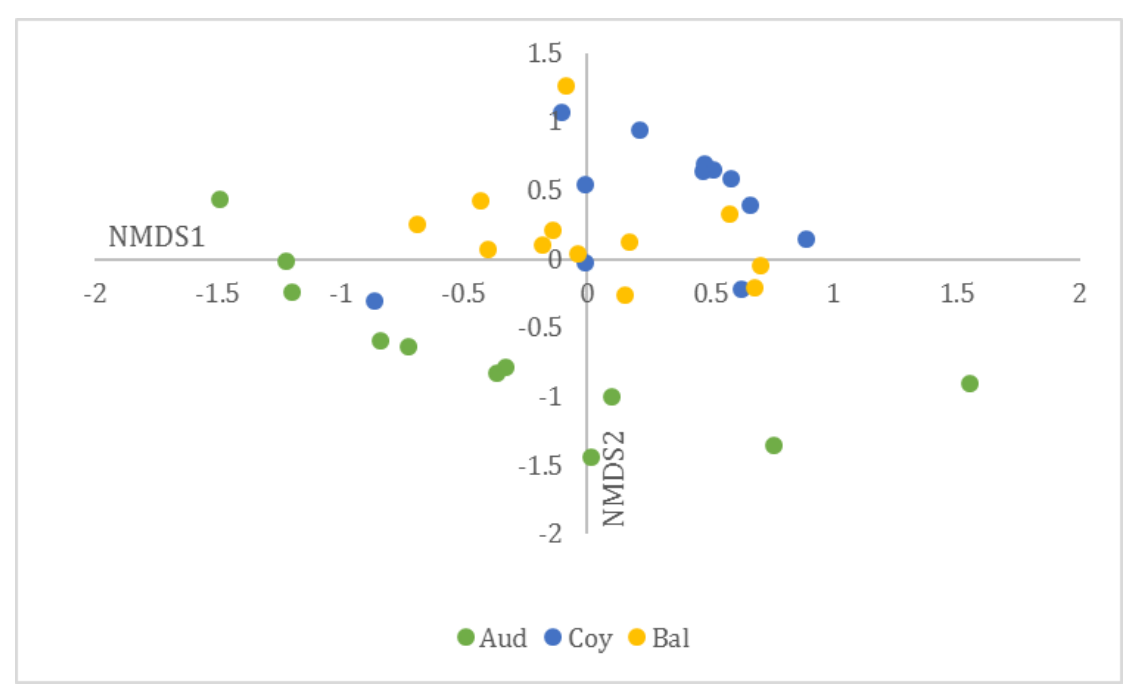

Figure 41: NMDS ordination of shrub community composition by site at the site scale, comparing the three permanent research plots.

Species ordination found that ivy and four shrub species had a significant $(\mathrm{p}<0.05)$ influence on community composition (Fig. 42). 


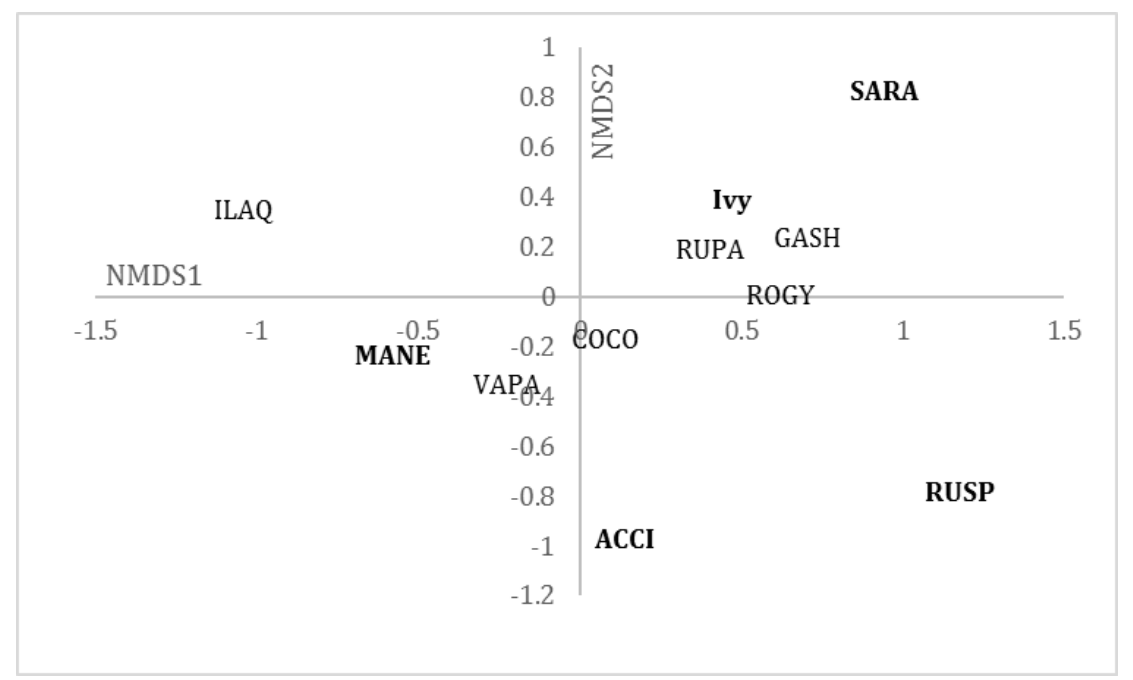

Figure 42: NMDS ordination of shrub community composition by species at the site scale. Species significant $(\mathrm{p}<0.05)$ to the model are in bold.

Ivy is the most important species to the site-scale community composition model, followed by $R$. spectabilis, $A$. circinatum, $M$. nervosa, and S. racemosa (Fig. 43).

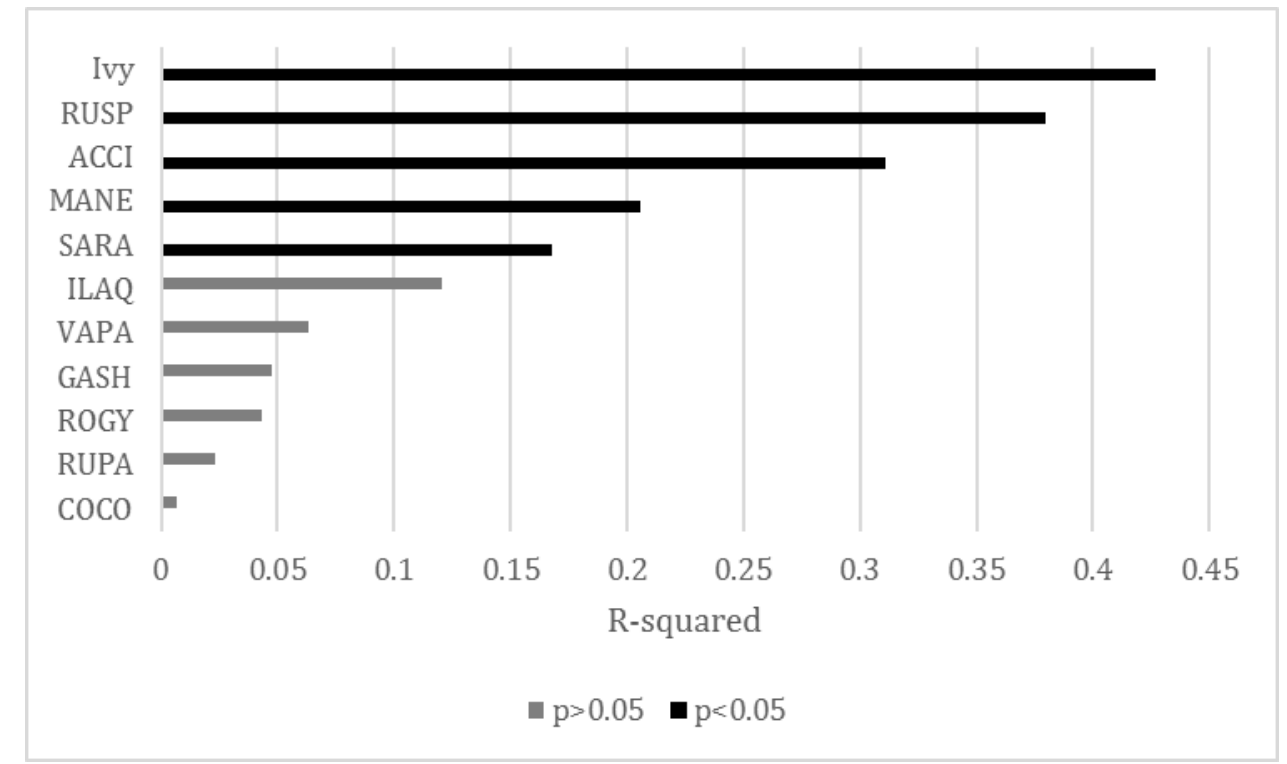

Figure 43: Importance of species to the shrub community NMDS ordination at the site scale. 
$\mathrm{RF}$ regression failed to produce an effective model of the shrub community at any number of species, but $M$. nervosa and $A$. circinatum consistently emerged as the two most important species (Fig. 44).
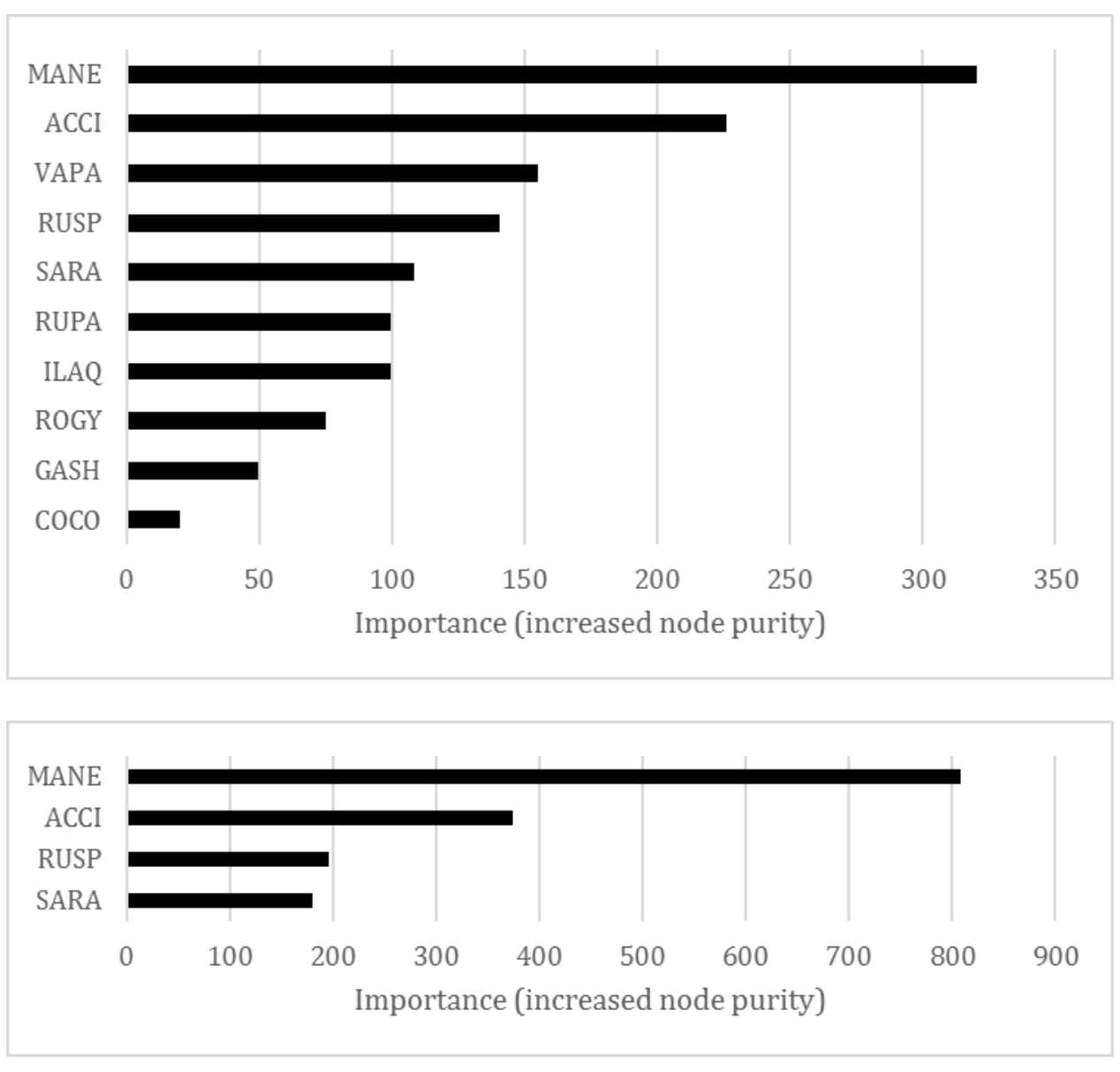

Figure 44: Relative importance of shrub species (measured as increased node purity) to the full (top) and strongest reduced (bottom) Random Forest regression models of ivy vs. shrub community composition at the site scale. Neither model explained any variance in ivy. 


\section{Discussion}

\section{Key Findings}

Ivy's strong spatial autocorrelation across scales, and the importance of that spatial autocorrelation among environmental predictors, could be interpreted in multiple, non-exclusive ways. One possibility at the landscape scale is that the stressed conditions under which it thrives, and/or the niche vacancies enabling it to dominate understory communities, are determined by gradients of urban influence and localized disturbance (Broshot, 1999; Cameron et al., 2015); another is that its limited dispersal ability (Metcalfe, 2005) means it is still expanding into suitable habitat from a few source populations. Perhaps not surprisingly, each of the apparent ivy epicenters is along the eastern, more urbanized edge of the park, particularly clustered around roads and residential areas. These are areas where ivy was especially likely to have been planted for erosion control or ornamental value, and may have taken advantage of disturbed conditions to invade the surrounding forest (M. Johnson, 2018). Conversely, areas away from these apparent epicenters often have little to no ivy, even when adjacent to roads, residential areas, or other possible sources, suggesting that establishment history and spatial autocorrelation-that is to say, the origin and radiative spread of source populations - may be at least as important as environmental conditions in determining where ivy occurs on the landscape, even at fine scales, which has been found for other invasive plants (Štajerová et al., 2017; Tanentzap et al., 2010). The 
important role of spatial dependency in each of the predictor analyses reinforces this impression. However, a lack of data on change over time means these trends are only speculative.

The distributions of ivy and several other variables paint a broad portrait of a rough, asymmetric urban-rural gradient in the park; several environmental variables were at least somewhat covariate, particularly with interiority, which emerged as a fairly strong landscape-scale predictor. This does not necessarily mean, however, that interior habitat is more resistant to ivy invasion, given the possible effect of dispersal limitation. Soil quality also appeared to be a significant predictor at the landscape scale, perhaps indicating that ivy is more tolerant of shallow, eroded soils than its potential competitors, though this could also be coincidental. The relative importance of slope variance (which was fairly strongly covariate with soil quality) at all scales could reflect this, as well.

Although ivy's seasonal growth patterns relative to deciduous canopy (Leuzinger et al., 2011) suggests that coniferous canopy would be a negative indicator, I found no significant relationship at any scale. Soil moisture, spanning a limited range of values, was influential at the site scale, but TWI was one of the weakest predictors at the two broader scales; Chance et al. (2016) suggest that ivy might have a quadratic, rather than linear, relationship with TWI, and the three Balch Creek plots, all at higher elevations, could simply represent a narrow, monotonic portion of the range of potential values. 
Shrub community composition appeared to shift across a gradient of ivy abundance to some extent at all scales, although ivy itself could be generating the signal more than any other constituent of the community due to its skewed distribution and occasional very high abundance values. The low-growing, evergreen shrub M. nervosa had a very strong negative correlation with ivy at all scales, presumably due to competitive niche exclusion in one or both directions; the same could be expected of $G$. shallon, but it was not detected often enough to produce clear trends at any scale (and was missing from the intermediate-scale analysis entirely, with only 3 detections in the sample). Generalized shrub metrics, with the exception of relative evergreen shrub abundance at the intermediate scale (which included an especially high percentage of M. nervosa), largely did not emerge as important predictors of ivy abundance, although they were frequently important to ordination models of the overall ecology. A. circinatum, meanwhile, showed up as a significantly predictive species across all scales despite being weakly and inconsistently correlated with ivy. Corylus species, both the native C. cornuta and exotic C. avellana (presumably both counted as C. cornuta in the UMP and permanent plot data), were significant positive correlates with ivy at the landscape scale, as expected (Madrigal-Gonzalez et al., 2018), but I found no such relationship at finer scales perhaps due to fewer detections.

Study Limitations

Landscape-Scale Data 
The landscape-scale analysis was based on fundamentally limited data. Vegetation units were determined by a relatively crude remote-sensing methodology based on canopy composition, and groundtruthing only merged or split a few units rather than correcting boundaries. All vegetation data were recorded as broad cover classes, and the pace of survey activity means that even these low-precision measurements are, in many cases, likely to be inaccurate or subjective, particularly for larger polygons.

Another shortcoming of this analysis was temporal misalignment of data. While I sought to minimize this using archived Regional Land Information System (RLIS) data as much as possible, the data still span dates from as early as 1983 (NRCS soil surveys) to as recent as 2018 (TWI) and may not always reflect conditions as they were in 2004, when the bulk of the vegetation surveys occurred. And, while it was still possible to study general principles with an old dataset, it means that the analysis is no longer directly relevant to managers in 2019 and beyond.

While I had access to road and trail shapefiles and was able to generate impact buffers based on some field measurements, the general accuracy of these data are questionable. The actual graded footprints of many trails, particularly those which follow old road grades, can be highly variable, the given width classification of many trails appeared dubious, and the field-calibrated buffers I generated around Germantown Road and Leif Erikson Drive were narrower than the associated gaps around those features between vegetation polygons, meaning that two of the largest 
road footprints were barely captured within the adjacent GIS features. In addition, these reflected only official trails and not informal trails or cutoffs, which have their own ecological ramifications in Forest Park (Van Winkle, 2014). Consequently, the road/trail impact variable is almost certainly an underestimate in many parts of the park. The percent interior variable is based on somewhat arbitrary units, as estimates of ecological edge effects can range widely depending on the process/organism and ecosystem being studied (Fischer \& Lindenmayer, 2007). Intermediate-Scale Data

The number of shrub species (8) with usable detection numbers at the intermediate scale was lower than either the landscape (15) or site (11) scales despite a larger sample size, and several species of interest were effectively absent. Identification of the two ivy species was questionable, and combining the numbers might have inflated some counts. Most concerning was the suspiciously strong positive correlation between shrub abundance and ivy abundance, which did not show up at the landscape or site scales and could be a product of inconsistent or even incomplete sampling. Finally, while intended as "pre-treatment" data, many of the Balch I UMP points were located on sites of earlier, piecemeal treatment efforts, along with other past disturbances (intentional or otherwise), which have not always been well documented.

\section{Site Scale}

The site-scale analysis was primarily limited by small sample size, both in terms of macroplots $(n=3)$ and samples per macroplot $(n=6$ for predictors, $n=12$ for 
shrubs), which is likely why there were fewer shrub species detected at usable counts in the site-scale data (11) than in the landscape-scale data (15). This low sample diversity means that many species of interest for restoration use, including some which seem to be correlated to ivy abundance from my landscape-scale analysis or from other research (Copp, 2014; Quinn \& Best, 2002; Ramsey, 2005), could not be effectively analyzed at the site scale. Fitting together variables which had been measured across multiple years (though to a much lesser extent than the landscape variables) and in different sample units was another potential source of error, and was the primary reason for the small per-plot sample size. And, while I did not detect any spatial autocorrelation in the shrub data I used, the sample design does not ensure that those measurements are functionally spatially independent. Future Research

This analysis highlighted the challenges of working with monitoring datasets when those datasets are not designed with a particular research goal and methodology in mind. Clear, meaningful conclusions are difficult to draw from data which have few replicates, are not spatially independent (unless spatial relationships are a research question), exist in different frames of reference or levels of detail, are measured by inconsistent methods or in different seasons and years, or lack important variables. This is not necessarily a failure of the data, if their purpose is to document project-specific, goal-driven outcomes, but it can create a barrier to effective scientific analysis of ecosystem management, and widens the disconnect between the two disciplines (Esler et al., 2010). 
The Forest Park dataset most in need of updating is the landscape inventory, due to its age, uncertain accuracy, and coarse resolution. Remote sensing, which combines high resolution, broad extent, and consistent classification, offers perhaps the best opportunity to improve upon these data. Chance et al. (2016) have developed a spectral-analysis signature which can detect ivy with $>80 \%$ accuracy in complex urban landscapes using a combination of LiDAR and hyperspectral data, which could provide a reasonably accurate, fine-grained landscape distribution at relatively low cost, though some groundtruthing would still almost certainly be required. Such a layer would enable further analysis, possibly with some number of added or improved predictors, focused on searching for synergistic or compensating interactions between ecological variables (Huston, 2004) at multiple spatial and temporal scales.

Other environmental variables which research suggests are important to ivy ecology, such as air quality (Della Torre et al., 1998; Saxe, 1994), solar radiation (Chance et al., 2016), or soil nutrients (Dolan, 2013; Howard, Gurevitch, Hyatt, Carreiro, \& Lerdau, 2004) and microbiota (Robertson, 2015), could be developed at one or more spatial scales, as well. Some key variables could be measured for scales at which they are not currently available, as well, such as coarse woody debris at the landscape scale or soil conditions at the intermediate scale.

Further study should also focus on reconstructing the land-use and disturbance history of Forest Park, and quantify the legacy effects which might be invisibly shaping current conditions and future trends, including plant community 
composition (A. L. Johnson, Tauzer, \& Swan, 2015) and species invasions (Beauséjour et al., 2015; Hobbs, 1989). While logging, fires, major soil and hydrological disturbances, and intentional ivy propagation are all known to have occurred in Forest Park, only wildfire has been well-documented in both spatial and temporal terms (Kuhn, 2005), though some landslide areas have been mapped (Burns et al., 2011). More extensive dendrochronological sampling, topographical and canopy structure analysis, woody debris surveys, and historical imagery each might help infer missing details (Lee, Wickham, Beedlow, Waschmann, \& Tingey, 2017; Spies, Franklin, \& Thomas, 1988).

Determining the causal relationship between ivy invasion and shrub community shift - whether ivy is displacing native vegetation or filling the void when that vegetation is already in decline (Quinn \& Best, 2002) (Fig. 19)—would require time-series data collected over a long period, though it could potentially be inferred by sampling shrub communities at multiple points along an invasion gradient. Combining this study with analysis of disturbance indicators, competition (e.g., seasonal water stress), and/or assessment of vegetation mortality could help prove or disprove the ivy-as-stress-tolerator hypothesis (Grime, 1977), while species-specific dynamics would inform which shrubs to choose for revegetation projects under different conditions. 


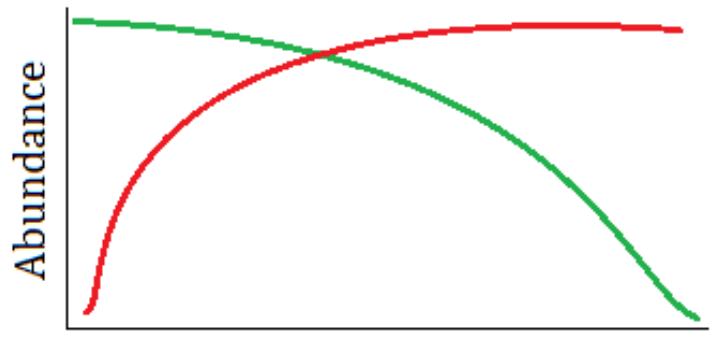

Ivy | Shrubs Time

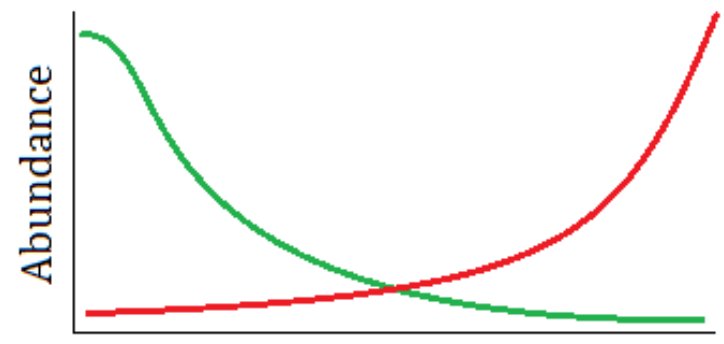

Time

Figure 45: Predicted abundance trends of ivy and functionally similar shrubs under the superior-competitor hypothesis (L) and under the opportunistic-invader hypothesis (R).

New data on ivy distribution, environmental metrics, and land-use history would enable stronger statistical analysis of both predictors and pattern. These two together could then be developed into a landscape conductance model (Dickson et al., 2019; McRae, Dickson, Keitt, \& Shah, 2008), which could forecast at high resolution where ivy is most likely to expand its range, given stochastic effects such as dispersal distance or establishment success (Tilman, 2004).

\section{Management Implications}

Ivy, though widespread, is not ubiquitous in Forest Park. The heaviest infestations appear to be centered in areas of high propagule pressure and urban ecological stress, while the interior forest is relatively uninvaded. This suggests that a "protect the best and restore the rest" approach should focus on points of vulnerability across the landscape: holding and pushing back the edges of invasion pools, especially where the environmental risk of spread is highest; monitoring rural/interior areas of relatively high disturbance (e.g. trailheads, road edges, utility corridors, etc.); and concentrating on tree rescue to prevent spread by seed. 
Managers should also monitor vegetation communities in invaded or vulnerable areas: declines in certain species, or in woody debris, could indicate a forest in a state of resilience debt, where ongoing and future heavy invasion by ivy and other problematic species is especially likely.

Conversely, some areas—conifer-dominated patches, deep interior areas, sites with robust understory communities—may be at substantially less risk, and can be made lower monitoring priorities. Other areas—road embankments, cliff faces, areas adjacent to ivy-infested private lots-could be beyond possibility of effective, sustainable ivy control. Managers should accept ivy as a permanent and even useful part of these novel ecosystems, and direct their scarce resources elsewhere. A decision framework such as that proposed by Hobbs et al. (2014) is especially valuable when the landscape contains a complex mixture of natural, novel, and intermediate ecological communities and conditions.

Finally, long-term ecological research (LTER) (Magnuson, 1990) and monitoring can document shifts in plant communities and other ecological factors over time. LTER is one of the bedrock components of adaptive management, which in a diverse and variably impacted landscape such as Forest Park is essential where future ecological conditions and functionality are unpredictable at any scale (Millar, Stephenson, \& Stephens, 2007; Radeloff et al., 2015). 


\section{$\underline{\text { References }}$}

Abrego, N., \& Salcedo, I. (2013). Variety of woody debris as the factor influencing wood-inhabiting fungal richness and assemblages: Is it a question of quantity or quality? Forest Ecology and Management, 291, 377-385.

Addessi, A. D. (2017). Urban Impacts to Forest Productivity, Soil Quality, and Canopy Structure in Forest Park, Portland, Oregon (Master's thesis). Portland State University, Portland, OR.

Alberti, M. (2005). The effects of urban patterns on ecosystem function. International Regional Science Review, 28(2), 168-192.

Allen, E. B., Temple, P. J., Bytnerowicz, A., Arbaugh, M. J., Sirulnik, A. G., \& Rao, L. E. (2007). Patterns of understory diversity in mixed coniferous forests of southern California impacted by air pollution. The Scientific World Journal, 7, 247-263.

Barbarasch, B. M. (2005). Effects of surrounding land use on plant species composition in urban forest fragments (Master's thesis). Portland State University, Portland, OR.

Barnea, A., Harborne, J. B., \& Pannell, C. (1993). What part of fleshy fruits contain secondary components toxic to birds and why? Biochemical Systematics and Ecology, 21(4), 421-429. 
Bartuszevige, A. M., Gorchov, D. L., \& Raab, L. (2006). The relative importance of landscape and community features in the invasion of an exotic shrub in a fragmented landscape. Ecography, 29(2), 213-222.

Beauchamp, V. B., Ghuznavi, N., Koontz, S. M., \& Roberts, R. P. (2013). Edges, exotics and deer: the seed bank of a suburban secondary successional temperate deciduous forest. Applied Vegetation Science, 16(4), 571-584.

Beauséjour, R., Handa, I. T., Lechowicz, M. J., Gilbert, B., \& Vellend, M. (2015). Historical anthropogenic disturbances influence patterns of non-native earthworm and plant invasions in a temperate primary forest. Biological Invasions, 17(4), 1267-1281.

Biggerstaff, M. S., \& Beck, C. W. (2007a). Effects of English Ivy (Hedera helix) on Seed Bank Formation and Germination. American Midlands Naturalist, 157(2), $250-257$.

Biggerstaff, M. S., \& Beck, C. W. (2007b). Effects of method of English Ivy removal and seed addition on regeneration of vegetation in a southeastern piedmont forest. American Midlands Naturalist, 158(1), 206-220.

Breiman, L. (2001). Random Forests. Machine Learning, 45, 5-32.

Broshot, N. E. (1999). The Effects of Urbanization and Human Disturbance Upon Plant Community Structure and Bird Species Richness, Diversity, and Abundance in a Natural Forested Area (Forest Park) in Portland, Oregon (Dissertation). Portland State University, Portland, OR. 
Broshot, N. E. (2011). Mortality and recruitment in an urban forest (Forest Park in Portland, Oregon) between 1993 and 2003. Urban Ecosystems, 14(4), 554567.

Burns, W., Madin, I., Ma, L., Mickelson, K., \& Saint-Pierre, E. (2011). SLIDO r2 2011 Landslide Deposits. Oregon Department of Geology \& Mineral Industries.

Cameron, G. N., Culley, T. M., Kolbe, S. E., Miller, A. I., \& Matter, S. F. (2015). Effects of urbanization on herbaceous forest vegetation: the relative impacts of soil, geography, forest composition, human access, and an invasive shrub. Urban Ecosystems, 18(4), 1051-1069.

Canopy 2007. (2016). Metro Data Resource Center.

Castagneri, D., Garbarino, M., \& Nola, P. (2013). Host preference and growth patterns of ivy (Hedera helix L.) in a temperate alluvial forest. Plant Ecology, 214(1), 19.

Cavanagh, J.-A. E., Zawar-Reza, P., \& Wilson, J. G. (2009). Spatial attenuation of ambient particulate matter air pollution within an urbanised native forest patch. Urban Forestry and Urban Greening, 8(1), 21-30.

Chance, C. M., Coops, N. C., Plowright, A. A., Tooke, T. R., Christen, A., \& Aven, N. (2016). Invasive Shrub Mapping in an Urban Environment from Hyperspectral and LiDAR-Derived Attributes. Frontiers in Plant Science, 7, Article 1528. 
Clarke, M. M., Reichard, S. H., \& Hamilton, C. W. (2006). Prevalence of different horticultural taxa of ivy (Hedera spp., Araliaceae) in invading populations. Biological Invasions, 8(2), 149-157.

Clements, H., \& Bierzychudek, P. (2017). Can the Persistent Seed Bank Contribute to the Passive Restoration of Urban Forest Fragments After Invasive Species Removal? Ecological Restoration, 35(2), 156-166.

Copp, S. (2014). Community level impacts associated with the invasion of English ivy (Hedera spp.) in Forest Park: a look at the impacts of ivy on community composition and soil moisture (Master's thesis). Portland State University, Portland, OR.

Dark, S. J. (2004). The biogeography of invasive alien plants in California: an application of GIS and spatial regression analysis. Diversity \& Distributions, 10(1), 1-9.

Davis, A. J. S., Singh, K. K., Thill, J.-C., Meentemeyer, R. K., \& Peters, D. P. C. (2016). Accounting for residential propagule pressure improves prediction of urban plant invasion. Ecosphere, 7(3).

Della Torre, G., Ferranti, F., Lupatelli, M., Pocceschi, N., Figoli, A., Nali, C., \& Lorenzini, G. (1998). Effects of ozone on morpho-anatomy and physiology of Hedera helix. Chemosphere, 36(4-5), 651-656.

Dickson, B. G., Albano, C. M., Anantharaman, R., Beier, P., Fargione, J., Graves, T. A., ... Theobald, D. M. (2019). Circuit-theory applications to connectivity science and conservation. Conservation Biology, 33(2), 239-249. 
Dlugosch, K. M. (2005). Understory community changes associated with English Ivy invasions in Seattle's urban parks. Northwest Science, 79, 52-59.

Dlugosch, K. M., Cang, F. A., Barker, B. S., Andonian, K., Swope, S. M., \& Rieseberg, L. H. (2015). Evolution of invasiveness through increased resource use in a vacant niche. Nature Plants, 1(6), 15066.

Dolan, B. C. (2013). Effects of increased nitrogen deposition on the dominance of Hedera helix in the Pacific Northwest (Master's thesis). Portland State University, Portland, OR.

Dresner, M. (2018). [In person interview].

Dresner, M., McDonald, H. B., \& Addessi, A. D. (n.d.). Shrubs 2011-2017.

Dresner, M., Van Winkle, J., \& Franz, S. C. (2017). Tree composition and abundance patterns differ in two watersheds of Forest Park, a large Pacific Northwest urban forest. Arboricultural Journal, 39(4), 208-225.

Esler, K. J., Prozesky, H., Sharma, G. P., \& McGeoch, M. (2010). How wide is the "knowing-doing" gap in invasion biology? Biological Invasions, $12(12 \mathrm{SI})$, 4065-4075.

Ettinger, A. K., Lee, B. R., \& Montgomery, S. (2017). Seed limitation and lack of downed wood, not invasive species, threaten conifer regeneration in an urban forest. Urban Ecosystems, 20(4), 877-887.

Farmer, S., Ward, J. R., Horton, J. L., \& Clarke, H. D. (2016). Southern Appalachian urban forest response to three invasive plant removal treatments. Management of Biological Invasion, 7(4), 329-342. 
Fischer, J., \& Lindenmayer, D. B. (2007). Landscape modification and habitat fragmentation: a synthesis. Global Ecology and Biogeography, 16, 265-280.

Forest Park Conservancy, Portland Parks and Recreation, Metro, \& West Multnomah Soil and Water Conservation District. (2016). Uniform Monitoring Protocol for the Greater Forest Park Ecosystem.

Getis, A., \& Ord, J. K. (1992). The analysis of spatial association by use of distance statistics. Geographical Analysis, 24(3), 189-207.

Gilkey, H. M., \& Dennis, L. R. J. (2001). Handbook of Northwestern Plants. Corvallis, OR: Oregon State University Press.

Green, G. L. (1983). Soil Survey of Multnomah County, Oregon. Retrieved from https://www.nrcs.usda.gov/Internet/FSE_MANUSCRIPTS/oregon/OR051/0 /or051_text.pdf

Grime, J. P. (1977). Evidence for existence of three primary strategies in plants and its relevance to ecological and evolutionary theory. American Naturalist, 111(982), 1169-1194.

Grimm, N. B., Foster, D., Groffman, P., Grove, J. M., Hopkinson, C. S., Nadelhoffer, K. J., ... Peters, D. P. C. (2008). The changing landscape: ecosystem responses to urbanization and pollution across climatic and societal gradients. Frontiers in Ecology and the Environment, 6(5), 264-272.

Hallett, L. M., Chapple, D. E., Bickart, N., Cherbowski, A., Fernandez, L., Ho, C. H., ... Suding, K. N. (2017). Trait Complementarity Enhances Native Plant 
Restoration in an Invaded Urban Landscape. Ecological Restoration, 35(2), 148-155.

Heckman, A. M. (2007). Soil properties associated with English ivy (Hedera spp) infestations in Pacific Northwest urban forests (Master's thesis). University of Washington, Seattle, WA.

Hobbs, R. J. (1989). The nature and effects of disturbance relative to species invasions. In Biological Invasions: A Global Perspective (pp. 389-403). Chichester, NY: John Wiley \& Sons.

Hobbs, R. J., Higgs, E., Hall, C. M., Bridgewater, P., Chapin III, F. S., Ellis, E. C., ... Yung, L. (2014). Managing the whole landscape: historical, hybrid, and novel ecosystems. Frontiers in Ecology and the Environment, 12(10), 557-564.

Holloway, L., \& Rosenstiel, T. (2013). Physiological response of invasive ivy (Hedera spp.) to the seasonal light cycle: taking photosynthetic advantage of winter canopy loss. Poster presented at the Northwest Science Association Annual Meeting, Portland, OR.

Houle, M. C. (1988). One City's Wilderness: Portland's Forest Park. Portland, OR: Oregon Historical Society Press.

Howard, T. G., Gurevitch, J., Hyatt, L., Carreiro, M., \& Lerdau, M. (2004). Forest invasibility in communities in southeastern New York. Biological Invasions, 6, 393-410. 
Huston, M. A. (2004). Management strategies for plant invasions: manipulating productivity, disturbance, and competition. Diversity \& Distributions, 10(3), 167-178.

Johnson, A. L., Tauzer, E. C., \& Swan, C. M. (2015). Human legacies differentially organize functional and phylogenetic diversity of urban herbaceous plant communities at multiple spatial scales. Applied Vegetation Science, 18(3), 513-527.

Johnson, M. (2018). [In person interview].

Johnstone, J. F., Allen, C. D., Franklin, J. F., Frelich, L. E., Harvey, B. J., Higuera, P. E., ... Turner, M. G. (2016). Changing disturbance regimes, ecological memory, and forest resilience. Frontiers in Ecology and the Environment, 14(7), 369-378.

Jung, S.-I., Park, S.-A., Kim, M.-J., Son, K.-C., Kim, P.-G., Lee, J.-C., \& Kays, S. J. (2010). Sensitivity and Photosynthetic Response of Indoor Plant Species to Ozone Exposure Duration. Horticulture Environment and Biotechnology, 51(5), 453462.

Kettenring, K. M., \& Adams, C. R. (2011). Lessons learned from invasive plant control experiments: a systematic review and meta-analysis. Journal of Applied Ecology, 48(4), 970-979.

Kollmann, J., \& Grubb, P. J. (1999). Recruitment of fleshy-fruited species under different shrub species: Control by under-canopy environment. Ecological Research, 14(1), 9-21. 
Kruskal, J. B. (1964). Nonmetric multidimensional scaling: a numerical method. Psychometrika, 29, 115-129.

Kuhn, D. M. (2005). Fuel model development and fire simulation analysis in the wildland-urban interface: the case of Forest Park, Portland, Oregon (Master's thesis). Portland State University, Portland, OR.

Ladwig, L. M., \& Meiners, S. J. (2009). Impacts of temperate lianas on tree growth in young deciduous forests. Forest Ecology and Management, 259(2), 195-200.

Lee, E. H., Wickham, C., Beedlow, P. A., Waschmann, R. S., \& Tingey, D. T. (2017). A likelihood-based time series modeling approach for application in dendrochronology to examine the growth-climate relations and forest disturbance history. Dendrochronologia, 45, 132-144.

Leicht-Young, S. A., Pavlovic, N. B., Frohnapple, K. J., \& Grundel, R. (2010). Liana habitat and host preferences in northern temperate forests. Forest Ecology and Management, 260(9), 1467-1477.

Leuzinger, S., Hartmann, A., \& Korner, C. (2011). Water relations of climbing ivy in a temperate forest. Planta, 233(6), 1087-1096.

Liaw, A., \& Wiener, M. (2002). Classification and Regression by randomForest. $R$ News, 2/3, 18-22.

Londre, R. A., \& Schnitzer, S. A. (2006). The distribution of lianas and their change in abundance in temperate forests over the past 45 years. Ecology, 87(12), 2973-2978. 
Madrigal-Gonzalez, J., Rios, R. S., Aragon, C. F., \& Gianoli, E. (2018). Indirect facilitation by a liana might explain the dominance of a small tree in a temperate forest. Journal of Plant Ecology, 11(4), 604-612.

Magnuson, J. J. (1990). Long-Term Ecological Research and the Invisible Present. BioScience, 40(7), 495-501.

Mandryk, A. M., \& Wein, R. W. (2006). Exotic vascular plant invasiveness and forest invasibility in urban boreal forest types. Biological Invasions, 8(8), 16511662.

Manzanedo, R. D., Ballesteros-Cánovas, J., Schenk, F., Stoffel, M., Fischer, M., \& Allan, E. (2018). Increase in CO2 concentration could alter the response of Hedera helix to climate change. Ecology and Evolution, 8(16), 8598-8606.

McGlone, C. M., Sieg, C. H., \& Kolb, T. E. (2011). Invasion resistance and persistence: established plants win, even with disturbance and high propagule pressure. Biological Invasions, 13(2), 291-304.

McRae, B. H., Dickson, B. G., Keitt, T. H., \& Shah, V. B. (2008). Using Circuit Theory to Model Connectivity in Ecology, Evolution, and Conservation. Ecology, 89(10), $2712-2724$.

Metcalfe, D. J. (2005). Hedera helix L. Journal of Ecology, 93(3), 632-648.

Millar, C. I., Stephenson, N. L., \& Stephens, S. L. (2007). Climate change and the forests of the future: managing in the face of uncertainty. Ecological Applications, 17(8), 2145-2151. 
Minchin, P. R. (1987). An evaluation of relative robustness of techniques for ecological ordinations. Vegetatio, 69, 89-107.

Moran, P. A. P. (1950). Notes on Continuous Stochastic Phenomena. Biometrika, $37(1), 17-23$.

Myers, R. (2013). Greater Forest Park Conservation Initiative. Forest Park Conservancy.

OLC Metro 2014 Lidar Project. (2014). Oregon Department of Geology \& Mineral Industries.

Quinn, H., \& Best, R. (2002). English ivy in Stanley Park: Effects of the invasion and implications for management (Master's thesis). University of British Columbia, Vancouver, BC.

Radeloff, V. C., Williams, J. W., Bateman, B. L., Burke, K. D., Carter, S. K., Childress, E. S., ... Usinowicz, J. (2015). The rise of novelty in ecosystems. Ecological Applications, 25(8), 2051-2086.

Radosevich, S. R., Stubbs, M. M., \& Ghersa, C. M. (2003). Plant invasions - process and patterns. Weed Science, 51(2), 254-259.

Ramalho, C. E., Laliberte, E., Poot, P., \& Hobbs, R. (2018). Effects of fragmentation on the plant functional composition and diversity of remnant woodlands in a young and rapidly expanding city. Journal of Vegetation Science, 29(2), 285296.

Ramirez, A. R., Shandas, V., Rosenstiel, T., Prather, H., \& Aldrich, J. (2019). Hydraulic vulnerability of native trees is increased by urban heat. Conference 
presentation presented at the Urban Ecology Research Symposium, Portland, OR.

Ramsey, T. F. (2005). Invasion of English ivy (Hedera spp., Araliaceae) into Pacific Northwest Forests (Dissertation). University of Washington, Seattle, WA. Roads (Regional Land Information System dataset). (2011). Metro Data Resource Center.

Robertson, J. (2015). Effects of invasive English ivy (Hedera helix) on soil microflora (Undergraduate thesis). Reed College, Portland, OR.

Roy, S., Byrne, J., \& Pickering, C. M. (2012). A systematic quantitative review of urban tree benefits, costs, and assessment methods across cities in different climatic zones. Urban Forestry and Urban Greening, 11(4), 351-363.

Sack, L., \& Grubb, P. J. (2002). The combined impacts of deep shade and drought on the growth and biomass allocation of shade-tolerant woody seedlings. Oecologia, 131(2), 175-185.

Sando, R., Olsen, T. D., Kaiser, K. E., Haluska, T. L., \& Hockman-Wert, D. P. (2018). Physical CPGs -- Probability of Streamflow Permanence (PROSPER) Continuous Parameter Grids (CPGs). Retrieved from https://doi.org/10.5066/F7057F5M Saxe, H. (1994). RELATIVE SENSITIVITY OF GREENHOUSE POT PLANTS TO LONGTERM EXPOSURES OF NO-CONTAINING AND NO2-CONTAINING AIR. Environmental Pollution, 85(3), 283-290.

Shea, K., \& Chesson, P. (2002). Community ecology theory as a framework for biological invasions. Trends in Ecology and Evolution, 17(4), 170-176. 
Spies, T. A., Franklin, J. F., \& Thomas, T. B. (1988). Coarse woody debris in Douglasfir forests of western Oregon and Washington. Ecology, 69(6), 1689-1702.

Štajerová, K., Šmilauer, P., Brůna, J., \& Pyšek, P. (2017). Distribution of invasive plants in urban environment is strongly spatially structured. Landscape Ecology, 32(3), 681-692.

Stewart, E. (2018, February). So many weeds, so little time: Prioritizing use of limited resources. Research presentation presented at the Urban Ecology \& Conservation Symposium, Portland, OR.

Tanentzap, A. J., Bazely, D. R., \& Lafortezza, R. (2010). Diversity-invasibility relationships across multiple scales in disturbed forest understoreys. Biological Invasions, 12(7), 2105-2116.

Thomas, L. K. (1998). Topographic alterations, forest structure, and invasion by English ivy (Hedera helix L.) in the Rock Creek floodplain, Washington, DC. Natural Areas Journal, 18(2), 164-168.

Thompson, K., Bakker, J. P., \& Bekker, R. M. (1997). The Soil Seed Banks of North West Europe: Methodology, Density, and Longevity. Cambridge: Cambridge University Press.

Tilman, D. (2004). Niche tradeoffs, neutrality and community structure: A stochastic theory of resource competition, invasion and community assembly. PNAS, 101(30), 10854-10861.

Trails (Regional Land Information System dataset). (2011). Metro Data Resource Center. 
Turner, D. P., Conklin, D. R., \& Bolte, J. P. (2015). Projected climate change impacts on forest land cover and land use over the Willamette River Basin, Oregon, USA. Climatic Change, 133(2), 335-348.

Van Pelt, R., \& Franklin, J. F. (2000). Influence of canopy structure on the understory environment in tall, old-growth, conifer forests. Canadian Journal of Forest Research, 30(8), 1231-1245.

Van Winkle, J. (2014). Informal Trails and the Spread of Invasive Species in Urban Natural Areas: Spatial Analysis of Informal Trails and their Effects on Understory Plant Communities in Forest Park, Portland, Oregon (Master's thesis). Portland State University, Portland, OR.

Vegetation Mapping Project. (2011). Retrieved from https://www.portlandoregon.gov/bps/article/106047

Vegetation Unit Summaries for Forest Park. (2009). Retrieved from https://www.portlandoregon.gov/parks/44449?a=274085

Vidra, R. L., Shear, T. H., \& Wentworth, T. R. (2006). Testing the paradigms of exotic species invasion in urban riparian forests. Natural Areas Journal, 26(4), 339350.

Villasenor, N. R., Blanchard, W., \& Lindenmayer, D. B. (2016). Decline of forest structural elements across forest urban interfaces is stronger with high rather than low residential density. Basic and Applied Ecology, 17(5), 418427. 
With, K. A. (2002). The landscape ecology of invasive spread. Conservation Biology, 16(5), 1192-1203.

Woodcock, P., Halme, P., \& Edwards, D. P. (2015). Ecological effects of logging and approaches to mitigating impacts. In Routledge Handbook for Forest Ecology (pp. 422-435). Oxon, United Kingdom: Routledge.

Yaman, B. (2009). Comparative wood anatomy of ivy-hosting and non-hosting oriental plane (Platanus orientalis L.). Plant Biosystems, 143(2), 252-257.

Zotz, G., Cueni, N., \& Korner, C. (2006). In situ growth stimulation of a temperate zone liana (Hedera helix) in elevated C02. Functional Ecology, 20(5), 763769. 